SANDRA MARA MACIEL

toe

\title{
SAÚDE BUCAL INFANTIL: \\ A PARTICIPAÇÃO DA MÃE
}

Tese apresentada a Faculdade de Saúde Pública da Universidade de São Paulo, para obtenção do título de Doutor em Saúde Pública.

Orientadora: Profa.Márcia Faria Westphal

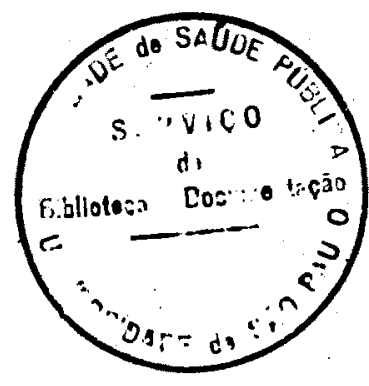




\section{SANDRA MARA MACIEL}

\section{SAÚDE BUCAL INFANTIL:}

\section{A PARTICIPAÇÃO DA MÃE}

Tese apresentada a Faculdade de Saúde
Pública da Universidade de São Paulo,
para obtencãa do título de Doutor em
Saúde Pública.
Orientadora: Profa.Márcia Faria Westphal

SÃo PAULO

1994 
Aos meus pais queridos, Arthur e Lourdes.

À minha adorada filha, Nathalia 


\section{AGRADECIMENTOS}

- A Marcia Faria Westphal, orientadora dedicada e pela grande confiança, compreensão e apoio, sempre demonstrados no seu decorrer. Por ter me ajudado a compreender melhor a dimensão social das questōes de saúde.

- A Nilza Nunes da Silva, pela amizade e pela colaboração nos procedimentos estatisticos.

- Ao Etevaldo Sousa dos Santos, pela disponibilidade e empenho, na infra-estrutura deste trabalho.

- A Regina ... pela precisa e árdua tarefa de digitação dos dados coletados.

- A Alexandrina, pelo apoio constante.

- Aos colegas da áréa de Odontopediatria da UEM: Carlos Conrado e Marina, com quem pude contar para cobrir minhas ausências.

- Aos colegas, amigos, professores e funcionários da Faculdade de Saúde Pública, com quem pude conviver mais, proximamente, durante este periodo.

- Às pessoas que auxiliaram no momento da coleta dos dados.

- À Secretaria Municipal de Saúde de Maringá, por ter oferecido todas as condições para que as entrevistas fossem realizadas:

- À Fundação de Amparo à Pesquisa do Estado de São Paulo, pelo financiamento deste trabalho. 
Í N D I C E 


\section{RESUMO}

\section{SUMMARY}

\section{I - INTRODUÇÃO}

1. O processo saúde-doença bucal infantil: algumas consideraçōes epidemiológicas.....

2. A saúde bucal infantil frente ao desempenho do setor odontologico

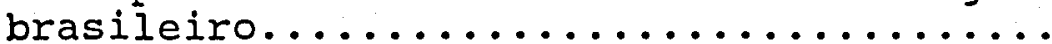

3. Participação da mãe nos cuidados de saúde bucal da criança pequena..............

II - OBJETIVOS

III- METODOLOGIA

1. opção Metodológica...................

2. Caracterização da área de estudo........

3. Delimitação do universo de estudo........

4. Procedimento de amostragem............ 64

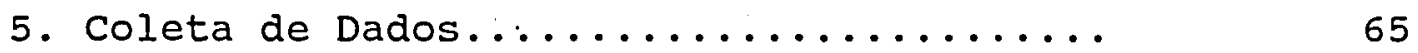

6. Levantamento dos dados.............. 68

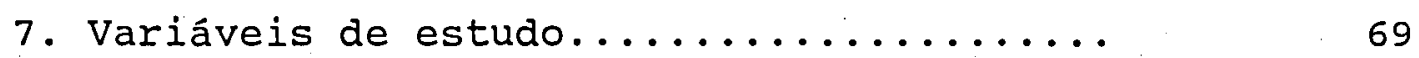

8. Processamento e Análise Estatística...... 72

\section{IV - RESULTADOS E DISCUSSÃO}

1. Características sócio-econômico-demográficas da população de estudo...........

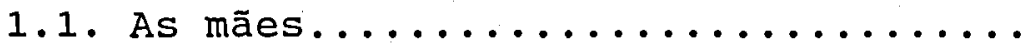

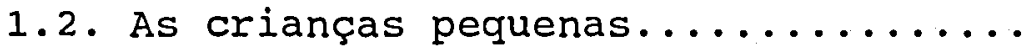


2. As mães e a saúde bucal..............

2.1. Representações sobre o processo saúde-doença bucal..............

2.2. Práticas em relação à saúde bucal...

3. Práticas da mãe com relação a saúde bucal da criança pequena................

3.1. Práticas alimentares da mãe em relação à criança e algumas representaçōes da relação com a saúde bucal infantil..............

3.2. Práticas e representaçōes da māe sobre a higiene bucal da criança....

3.3. Práticas e representações da mãe com relação ao uso do flúor............

3.4. Procura do dentista para criança...

4. Participação da mãe no cuidado da saúde bucal da criança pequena.............

$\mathrm{v}-$ CONCLUSõEs..................... 
R E S U M O 
o presente trabalho foi desenvolvido à partir do pressuposto de que a saúde bucal da criança pequena (bebês e pré-escolares) tem sido desconsiderada pelas politicas nacionais de saúde bucal, o que, consequentemente, acaba tendo repercussões no "conhecimento a nível de senso comum" das mães e práticas dele derivadas, com relação aos cuidados de saúde bucal de seus filhos menores.

Além disso, considerou-se que as representaçōes e práticas maternas, à cerca do processo saúde-doença bucal infantil, sofrem grandes influências culturais, sendo estas definidas pela posição da mãe na estrutura social.

- saber odontológico das mães foi buscado através de 554 entrevistas, realizadas em um dia de vacinação em massa, destinado a crianças com até 5 anos de idade, no município de Maringá-PR.

Através do material coletado, foi possível a identificação do conhecimento das mães à respeito da concepção, etiologia e prevenção da doença cárie dentária, bem como das práticas a ele associadas.

Procurou-se, também, avaliar as práticas maternas com relação à alimentação, higiene bucal e procura ao dentista, por motivos preventivos, para seus filhos pequenos. 
A análise global dos resultados deixou transparecer que a participação das mães nos cuidados de saúde bucal de seus filhos, constituiu-se em fator de risco a saúde bucal dos mesmos. As representações da maioria das mães sobre questões relativas ao processo saúde-doença, bem como suas práticas, foram consideradas conflitantes com o conhecimento técnico-cientŕfico odontológico. A situação mais crítica foi verificada entre familias pertencentes às classes sociais menos favorecidas. 
S U M M A R Y 
This study was developed by assuming that buccal health of the younger children (babies and preschool ones) has not been considered by buccal health national politics, which, becomes reflected in the mothers' common sense knowledge and in practices derived from it, regarding their smaller children's buccal health care.

Besides, it was considered that the mother's representations and practices about the infancy buccal health-disease process suffer great cultural influences, which are defined by the mother's position in social structure.

The mother's knowledge about dentistry was investigated through 554 interviews programmed during a mass vaccination day, directed to children from 0 to 5 years old, in the City of Maringá, state of Paraná.

Through the data collected, it was possible the identification of the mother's knowledge about the dental caries disease concept, ethiology and prevention, as well as the associated practices.

The mother's practices concerning feeding, buccal hygiene and regular visits to the dentist for preventive reasons were also assessed. 
A global analysis of the results showed to some extant. that the mother's participation in their children's buccal health care represented a risk factor to the children's buccal health.

The mother's representations about buccal healthdisease process questions as well as their practices were considered to be in disagreement with Dental technical and scientific knowledges. The most critical situation was observed in families belonging to the less favoured social classes. 
I. INTRODUÇÃO 


\section{0 processo saúde-doença bucal infantil: algumas consideraçōes epidemiológicas}

Ao longo da história da saúde, o processo saúdedoença tem sido estudado e descrito através de várias abordagens teóricas, que, em sua grande maioria, têm comtemplado o caráter estritamente biológico e individual da doença, transformando-o em paradigma do setor. contudo, em oposição à produção científica hegemônica, podemos identificar na literatura que, desde as primeiras décadas do século passado, já havia a preocupação, entre alguns estudiosos europeus, no sentido de identificar as relaçōes entre as condiçōes de vida e os problemas de saúde dos diversos grupos sociais ${ }^{12}$.

o reconhecimento das limitaçōes existentes no modelo biológico/individual para explicar com clareza a ocorrência desigual da doença nos diferentes grupos sociais e na sociedade, como um todo, contribuiu para que recentemente, na América Latina, alguns autores $10,23,40,58$ empreendessem a rediscussão da relação entre o biológico e o social nas questões pertinentes à saúde. Desse modo, segundo LAUREL 40 (1983), "Tem-se postulado que as causas da doença não devem ser buscadas apenas nos processos biológicos, ou em. caracteristicas da tríade ecológica, mas, também, nos processos sociais, na produção e reprodução social, retomando assim, as colocações de determinação social da doença". 
No caso especifico do processo saúde-doença bucal infantil, a partir da década de 80 este novo enfoque, que resgata a dimensão social dos problemas, passa a ser difundido por alguns pesquisadores, que concordam que as condições" de saúde/doença devam ser entendidas como expressão concreta da interação de aspectos biológicos, culturais, comportamentais e sociais definidores do processo de vida da criança.

Apesar da existência de um grupo de profissionais comprometidos com a compreensão da relação entre os dois campos de conhecimento, o "biológico" e o "social", visando o contrôle das doenças e a promoçāo da saúde bucal da coletividade, vale ressaltar que na odontologia, esta concepção mais ampla ao tratar as questões de saúde/doença bucal das populaçōes, em especial da infantil, tem se confrontado com o reducionismo biológico hegemônico no setor.

A primazia do biológico sobre o social pode ser detectada tanto na produção dos conhecimentos existentes, como no modelo de prática a eles vinculada.

As publicaçōes odontológicas, em geral, têm caráter técnico, com forte inclinação para os aspectos biológicos, clínicos ou laboratoriais. E, os dentistas continuam desenvolvendo suas práticas, como se as características principais que determinam os problemas de saúde na sociedade fossem biológicas. 
De acordo com BOTAzzo ${ }^{7}$ (1989), a odontologia desloca a questão da saúde bucal do contexto social."o ser em sua concretude, enquanto realidade social, com seus nexos sociais, é ignorado pela clinica odontológica". o autor considera que justificativas para este fato, podem ser encontradas a partir da exterioridade social da organizaçāo da prática odontológica, ou seja, acredita que haja uma desvinculaçāo entre a prática dos dentistas e as demais práticas de saúde. "Desde o século XIX, a odontologia é exercida com forte dose de autonomia; o dentista sozinho processando a cura (ao menos em tese); a ciência odontológica se bastando a si própria. Esta produção autônoma, ademais da independência, não é conexa aos processos sociais de produção do conhecimento cientifico e tecnológico as quais evidentemente se vincula".

As abordagens relacionadas à saúde bucal infantil, em sua grande maioria, não fugindo à regra, enfatizam os aspectos técnicos-biológicos das doenças. Além do que, tratam a criança como se fosse ahistórica e como se sua saúde bucal não dependesse das condiçōes de vida, do meio cultural de sua família e da classe social onde está inserida.

A negação do social contribui para a cristalização de pensamentos errôneos em nível de ensino e prática dos odontopediatras, como por exemplo, ao desconsiderarem a insersão social da criança, transformam a população infantil em uma população homogênea, e passam a acreditar que as condiçōes de saúde bucal das crianças estão diretamente 
associada ao cumprimento das normas odontológicas pelas mães desconsiderando condições desfavoráveis de ordem bio-psicosocial.

o presente trabalho constitui-se em uma tentativa de aproximação à articulação entre o biológico e o social, no que diz respeito aos prováveis fatores associados aos conhecimentos e práticas maternas com relação à saúde bucal própria e a de seus filhos.

Tendo como pressuposto que a doença bucal de maior prevalência na sociedade brasileira continua sendo a cárie dentária, e que esta é, rotineiramente vivenciada pela criança e sua familia, optamos por tê-la como referência ao abordarmos o processo saúde-doença bucal infantil. Dessa forma, pretende-se estudar algumas características maternas (biológicas, culturais e sociais) que poderiam estar atuando como fatores de risco ou proteção à cárie, para as crianças pequenas*.

Esta doença tem sido objeto constante de preocupação para os profissionais da área odontológica. Considerada a doença bucal mais comum, com raras exceçōes, é na infância que o indivíduo tem suas primeiras experiências, muitas vezes, em idades bem precoces e, não raro, traumatizantes.

* Consideramos crianças pequenas, aquelas que têm entre 0 e 5 anos de idade: os bebês e pré-escolares. 
Suas manifestações desde os primeiros anos de vida, encontram-se bem documentadas na literatura especifica $26,50,56,79,82$. Na qual encontramos também, referências a um tipo característico de cárie, a cárie rampante, que pode acometer crianças.

MCDONALD 50 (1977), relata-nos que esta doença tem aparecimento súbito, é de caráter agudo e agressivo, ataca e pode destruir rapidamente um grande número de dentes decíduos e está relacionada a hábitos alimentares pouco sadios, como o consumo frequente de alimentos açucarados entre as refeições principais, associados a higienização precária.

Em decorrência do prolongamento do aleitamento materno ou do uso de mamadeira com leite ou outra bebida açucarada, quando o bebê é posto para dormir, pode haver manifestação mais precoce da cárie rampante, desenvolvendo-se assim, a chamada "cárie de mamadeira", que atinge dentes decíduos recém-erupcionados, podendo acontecer a partir do primeiro ano de vida da criança.

A cárie de mamadeira, tida como uma forma grave de doença, foi identificada como um dos maiores problemas de saúde pública envolvendo as crianças pequenas norteamericanas (STEFFENSEN $\left.{ }^{76}, 1990\right)$.

com relação à manifestação aguda da cárie em crianças pequenas, os conhecimentos produzidos apontam para uma situação, no mínimo, contraditória. Por um lado, enfocam a gravidade do quadro clínico característico desta doença e suas consequientes dificuldades de resolução, como o domínio 
de técnicas especificas pelos profissionais, os tratamentos de alto custo que limitam as possibilidades de acesso a um número expressivo de familias e o baixo grau de maturidade da criança. Por outro, enfatizam a facilidade de sua prevenção, colocando de forma simplista, que esta depende basicamente da adoção de certos cuidados pelas mães com relação às práticas alimentares e de higiene de seus filhos pequenos.

No Brasil, apenas em anos recentes parece estar sendo despertada a consciência dos profissionais da área para importância de se conhecer mais profundamente as condiçōes reais de saúde bucal das crianças desde o nascimento.

o trabalho desenvolvido por WALTER e cols.73 encontra-se entre os pioneiros, com este tipo de preocupação. Os autores estudaram 235 bebês com idades variando entre 0 a 30 meses, procurando verificar a associação entre ocorrência de cárie dentária e hábitos alimentares. Chegaram a conclusão que os hábitos alimentares inadequados, sob o ponto de vista odontológico atingiam cerca de $34,04 \%$ da população estudada, sendo que, entre os bebês que recebiam alimentação imprópria, $18,72 \%$ apresentaram cárie de mamadeira. A cárie acometia a população de até 12 meses em cerca de 23,53\%, passando para $28,57 \%$ entre as idades de 12 a 24 meses e, finalmente, atingia cerca de $62,96 \%$ após os 24 meses.

Seguindo a mesma Iinha de investigação, WALTER e NAKAMA $^{86}(1992)$, publicaram os resultados de um estudo epidemiológico, sobre a prevalência da cárie dentária em 2.264 crianças entre. 0 a 30 meses de idade, no município de 
Londrina. Encontraram que 4,5\% das crianças entre 6 a 12 meses já apresentavam a doença, porcentagem que evoluiu para $28,5 \%$ na faixa etária entre 13 a 24 meses e que atingiu 49,1\% da população entre 25 a 36 meses de idade.

Embora estes resultados expressem a realidade epidemiológica do Município estudado, utilizamo-os como um indicador para avaliação da realidade regional e nacional, pois os dados oficiais sobre a ocorrência de cáries em crianças, pertencentes à faixa etária investigada são praticamente inexistentes.

Assim considerando, os achados destes autores são motivo de preocupação, pois é conhecido que os primeiros dentes decíduos iniciam sua erupção em média aos 6 meses de idade, e como visto, nesta época a criança já corre o risco de desenvolver cáries em seus dentes. Por volta dos 2 anos e meio de. idade, quando todos os dentes decíduos estão presentes na boca, aproximadamente $50 \%$ das crianças já entraram em contato com a doença, o que é grave, pois sabe-se que o problema é cumulativo, aumentando com o evoluir da idade e podendo levar à perda dos dentes, quando não controlado. Pode ainda, trazer repercussões negativas de natureza bio-psico-social para os pequenos, que se encontram em momento importante de seu processo de crescimento e desenvolvimento.

Sabe-se que as consequências das doenças bucais são onerosas para as pessoas, não apenas em termos de dispêndio de dinheiro e tempo, mas, também, pela dor, ansiedade, 
angústia decorrente da aparência pessoal e problemas de recorrências e cronicidade, sendo que suas sequelas os acometidos pela vida toda. Além disso, é significativo o número total de horas perdidas na escola e no trabalho, em função do problema (STEFFENSEN ${ }^{76}$, 1990).

Os números negativos que apontam para as precárias condições de saúde bucal da população infantil brasileira desde tenra idade, afetando a dentição decídua, extendem-se à dentição permanente, comprometendo crianças em idade escolar, adolescentes e a população adulta.

Resultados do primeiro estudo de abrangência nacional na área de saúde bucal, realizado pela Divisão Nacional de Saúde Bucal do Ministério da Saúde ${ }^{7}$ (1988), entre inúmeras informaçōes importantes fornecidas, confirmam que a partir dos 6 anos de idade há elevação gradativa da incidência da cárie dentária em todas as faixas etárias; apenas $13,8 \%$ das crianças entre 6 a 12 anos de idade estão isentas da doença; dos jovens na idade de 18 anos somente $33 \%$ conservam todos os seus dentes e é significativo o número de pessoas edêntulas na faixa etária dos 50 aos 59 anos.

os dados deste levantamento deixam transparecer a idéia de evolução natural desta doença no decorrer da vida das pessoas, culminando, quase sempre, com a perda dos dentes. A análise dos mesmos, permite-nos considerar que, além dos fatores relacionados a nivel de estrutura e superestrutura social, podem estar exercendo influências sobre esta evolução, aqueles relacionados aos níveis 
educacional e de renda, as possibilidades de consumo de bens e serviços e aos valores culturais, os quais se vinculam a inserção social dos diferentes grupos populacionais.

Paradoxalmente aos altos patamares ocupados pela cárie dentária em nosso país, deparamo-nos com a grande evolução dos conhecimentos cientificos e tecnológicos que tem ocorrido na área odontológica, os quais, além de permitir o aprimoramento das estratégias de tratamento e controle, têm criado possibilidades para prevenção das doenças. e promoção da saúde bucal em nivel individual e coletivo.

Assim, através da produção cientifica existente, percebemos estar havendo continua elucidação a respeito da doença cárie dentária, permitindo-nos conhecer o que é, a evolução de sua história natural, as tendências epidemiológicas básicas de seu desenvolvimento nas populações, suas causas, consequiencias, estratégias de tratamento, medidas preventivas a serem interpostas e, recentemente, a definição de grupos de risco.

A compreensão, cada vez mais apurada, sobre os diversos mecanismos envolvidos no aparecimento da cárie dentária, tem resultado no desenvolvimento de vários métodos preventivos da doença que vêm sendo testados e utilizados nas últimas décadas. A partir do resultado de estudos recentes, foram selecionadas algumas medidas, consideradas eficazes em prevenção primária como, o uso de flúor sistêmico na água, sal, tabletes, dropes e vitaminas; o uso de flúor tópico através de bochechos, dentifrícios ou aplicação profissional; 
selantes oclusais; higiene bucal, através de escovação diária com dentifricio com flúor; restrição de alimentos cariogênicos, especialmente os açucarados, entre as refeições principais, e o aleitamento materno ou uso de mamadeiras pelas crianças, por períodos não prolongados.

A aplicação destas medidas pode reduzir, substancialmente, a ocorrência da doença e contribuir para melhoria da saúde bucal das populações.

A literatura nos fornece evidências de que a promoção da saúde bucal infantil, objeto desta metas, quando encarada com seriedade por algumas naçōes industrializadas, tem levado ao declínio na prevalência da cárie dentária em crianças $55,62,71$.

Os pesquisadores têm buscado explicações para a eficácia na reversão do quadro de ocorrência da doença. Alguns estudos identificam que está diretamente associada ao aumento concomitante no consumo de dentifrícios contendo flúor pela população. Outros apontam para a combinação de várias influências como, melhores condições de vida, melhoria da educação do público, acesso aos cuidados bucais, aumento na compreensāo do processo da doença e, especialmente, o desenvolvimento de métodos para prevenir e controlar a doença, como fluoretação da água de consumo, flúor tópico e selante dental21,36,63,64.

Dentre os vários motivos procurados para justificar a substancial redução da doença em idades precoces na suécia, KINNBY e col.36 (1991) afirmaram haver consenso entre os 
pesquisadores que os fatores que mais contribuiram foram: "A ampliação da atenção à saúde bucal infantil e o desenvolvimento de ações educativas dirigidas aos pais sobre os cuidados preventivos com a cárie dentária nos centros de saúde da criança, os quais recebem, sistematicamente, as primeiras visitas das crianças quando têm 6,18 e 30 meses de idade".

A reorganização dos serviços públicos odontológicos na Noruega, no início dos anos 80 , com o propósito de se alcançar igualdade social e geográfica na distribuição destes serviços entre crianças e adolescentes, é apontada por ROSSOWW e HOLST 69 (1991) como o fator determinante para a melhoria do quadro de saúde bucal infantil.

Mediando o efeito satisfatório das medidas preventivas adotadas nos índices de saúde bucal entre crianças e adolescentes, nos países escandinavos, encontramos um pano de fundo composto pela qualidade de vida da população e pela implementação de políticas públicas, em especial, a "Politica Odontológica de Saúde".

o que se percebe é que as políticas públicas destes países voltaram-se para a ampliação do acesso aos serviços odontológicos, atuando assim na redistribuição de bens e serviços na sociedade, para que isto se fizesse de forma mais equitativa. É o que significa a adoção de medidas em nível macroestrutural da sociedade. 
Na literatura tem havido uma explosão de publicaçōes que vêm relatando o êxito obtido por algumas sociedades do primeiro mundo, no controle da doença cárie, a partir de uma associação da adoção de medidas na esfera redistributiva de serviços odontológicos e aumento do uso de medidas para promoção da saúde bucal a nível individual.

concordamos que a associação entre as políticas públicas adequadas, os conhecimentos científicos existentes e a introdução de ações educativas e preventivas o mais precocemente possível na vida dos indivíduos, de forma contínua, favorece, idealisticamente, a termos populaçōes "livres de cárie".

Contudo, saindo do plano do que seria o ideal e passando para o real, nos confrontamos, respeitando as devidas exceçōes, com o seguinte: as medidas preventivas para promover a saúde bucal infantil não são adequadamente aceitas, adotadas ou universalmente aplicadas tanto pelos profissionais de saúde como pelo público em geral. A consequência disto é um quadro de desigualdade em relação às condiçōes de saúde bucal da população infantil. Se em alguns países desenvolvidos há altas porcentagens de crianças e adolescentes "livres de cárie", em quase todos os países "em desenvolvimento" são alarmantes os índices da doença.

Parece-nos oportuno colocar que, na busca de prover melhores condições de saúde bucal à população mundial, a organização Mundial de Saúde e a Federação Dentária Internacional, em 1981, propuseram algumas metas a serem 
alcançadas até o ano 2000 , sendo duas delas relacionadas a saúde bucal infantil, "... 50\% das crianças com idade entre 5 e 6 anos livres de cárie e média de até 3 dentes cariados, perdidos ou obturados em indíviduos aos 12 anos de idade".

Temos particular interesse na primeira delas, pois diz respeito à população de nosso estudo.

2. A saúde bucal infantil frente ao desempenho do setor odontológico brasileiro

confrontando-nos, mais diretamente, com a problemática da saúde bucal infantil em nosso país, temos que a importação dos mesmos conteúdos científicos e tecnológicos empregados nos países desenvolvidos, pela comunidade odontológica brasileira, parece ter produzido pouco impacto para transformação do quadro de elevada ocorrência da cárie dentária na população infantil. As condições de saúde bucal das crianças continuam sujeitas às enormes desigualdades sociais e comportamentais existentes.

Sobre isto, MENÉNDEZ 52 (1979) comenta com propriedade que "o resultado da prática do uso abusivo e indiscriminado de medidas preventivas de forma acritica, sem adaptaçāo ao contexto brasileiro, sem continuidade, de forma extensiva e sem discussão pela sociedade civil, chega a ser iatrogênico: iatrogênico, individualmente, por muitas açōes indevidas e iatrogênico coletivamente por omissão à ampliação de ações adequadas à toda a população". 
É licito dizermos que fatores de natureza diversa contribuem para que, apesar da tendência preventiva existente, nāo estarem sendo registradas substanciais mudanças nos Indices de saúde bucal da população infantil, em nossa sociedade.

Há os fatores vinculados à politica social, conforme já mencionado, os quais foram muito bem apontados por LANDMAN $^{39}$ (1986), ao falar sobre as possibilidades de se obter saúde. Achamos conveniente repeti-los para analisar, a a partir de seu referencial, a situação brasileira. Para ele, elas dependem de "fatores que não estão ao alcance das disciplinas de saúde e sim da natureza da sociedade em geral, dos recursos alocados para, educação, alimentação, habitação, infra-estrutura sanitária, condiçōes de vida, condiçōes de trabalho, nível de salários, segurança no emprego. Dependem do estilo de vida e liberdade".

Outros fatores tratados pelos autores são inerentes à profissão odontológica, como o tipo de enfoque dado à produção científica, o modelo tradicional dominante de prática odontológica, o perfil do profissional formado alheio a seu papel social, o monopólio dos conhecimentos científicos pelos profissionais, as políticas de saúde do setor e o acesso desigual das pessoas aos serviços, às informaçōes e aos bens de consumo odontológico, sendo este definido por suas condições de classe. 
Com o presente trabalho, não temos a pretensão de realizar uma análise conjuntural ampla de todos estes fatores: Apenas nos limitamos a fazer algumas considerações sobre alguns pontos que consideramos serem importantes na determinação do processo saúde-doença bucal na infância brasileira, e que, fazem parte do processo de reflexão para a definição do nosso objeto de estudo.

Como um primeiro ponto a ser comentado, colocamos que, em nosso país, os profissionais têm acompanhado e alguns pesquisadores têm contribuido para a grande evolução dos conhecimentos científicos e tecnológicos verificada no campo odontológico, particularmente, nas áreas básica e clínica.

com relação à doença cárie dentária, que tomamos por referência em nosso estudo, há até uma nova disciplina sendo introduzida em alguns currículos odontológicos, a saber, a Cariologia 79.

Porém, acompanhando o enfoque dominante nas demais profissões de saúde, na odontologia, esta doença é vista sob a perspectiva quase que exclusivamente biológica, pouco se considerando sobre o provável papel de influências culturais e havendo escassas referências à sua determinação social.

Um bom exemplo do que estamos expondo é a citação de THYLSTRUP e FEJERSKOV ${ }^{79}$ (1988) no prefácio de seu Tratado de Cariologia, que tem sido referência nas diversas Faculdades de odontologia do pais. "Nos últimos anos tornouse evidente que a cárie dentária só pode ser previnida se a profissão odontológica tiver um conhecimento total das 
variáveis biológicas que influenciam o padrão da doença".

Ao destacarmos o reducionismo biológico vigente no setor, não significa que estamos negando as caracteristicas biológicas e técnicas da produção cientifica, ao contrário, sabemos de sua importância, mas temos, também, consciência de que 0 fato de os aspectos sócio-culturais serem, tradicionalmente, desconsiderados nas pesquisas realizadas e durante a formação profissional, contribui muito para perpetuação do modelo de prática odontológica hegemônico em nosso pais, de características essencialmente curativas, Iucrativas e individuais, bem como para reproduçāo do perfil do profissional, em especial daquele responsável pela atenção à saúde bucal infantil, que permanece desvinculado do contexto sócio-cultural em que exercerá suas atividades.

Tendo como pressuposto que os tipos de prática e assistência odontológica desenvolvidos no contexto nacional, encontram-se entre os fatores que tem contribuído, negativamente para a precária situação da saúde bucal na infância, achamos oportuno caracterizá-los.

- Relatório da $1^{a}$ Conferência Nacional de Saúde Bucal15 (1986) expressa que "o modelo atual de prática odontológica cobre as necessidades de somente $5 \%$ da população, caracteriza-se por sua ineficácia e ineficiência, sendo ainda monopolizador, de altos custos, de tecnologia densa, elitista, iatrogênico e mutilador". 
Quanto à situação da cobertura assistencial, esta é igualmente precária: "No setor privado, a prática odontológica atual, nitidamente curativa, por seus altos custos, torna-se acessível para tão somente 5\% da população, os quais consomem serviços odontológicos com freqüência regular; outros $15 \%$ servem-se desses mesmos serviços de modo irregular; ficando os demais, ou seja, $80 \%$ sujeitos a atendimentos eventuais e de urgência. Feitas algumas estimativas, o primeiro segmento contribuiria com $88 \%$ dos ingressos financeiros, ficando o segundo responsável por 11\% e cabendo ao terceiro contribuir com irrisório $1 \%$ do total dos ingressos da prática dos dentistas" (BOTAzzo 7 , 1989).

As tecnologias utilizadas, junto aos vários segmentos populacionais, são diferenciadas em função de sua remuneração, afirma $B \operatorname{TAZZO}^{7}(1989)$, pois no seu entender "A odontologia é exercida de modo diferenciado, segundo as classes sociais e as equivalentes possibilidades de consumo, exercendo-se em sua plenitude como ato lá junto aos segmentos que a ele agregam valor, possibilidade distante de ser realizada junto ao segmento queixoso que frequenta, os centros de saúde", e que, como sabemos, constitui-se na única possibilidade de atenção para maior parcela da população, em especial da infantil.

Por outro lado, o setor público apresenta oferta inelástica de serviços, operando com os mais variados modelos de atendimento e escassos recursos. sendo a única possibilidade de acesso a cuidados odontológicos a cerca de 
$80 \%$ da população, este setor financia apenas $18,2 \%$ dos custos com assistência odontológica no Brasil, enquanto que os demais $81,8 \%$ correspondem a gastos realizados no setor privado (NARVAI ${ }^{54}, 1993$ ).

Em documento técnico do Ministério da saúde 9 (1988), encontramos que "...os gastos do setor público, ademais de serem insuficientes, apresentam importantes problemas de distribuição por grupos populacionais. Dados de 1986 indicam que aproximadamente $52 \%$ dos recursos são destinados à atenção terciária da população adulta urbana e 6\% à rural, apoiando uma linha de atendimento por livre demanda, portanto sem programação. Só $35 \%$ estão alocados a programas de cuidados básicos ao grupo prioritário formado por escolares primários de 6 a 14 anos. Cinco por cento (5\%) são gastos em administraçāo e não mais que $2 \%$ em açōes coletivas de prevenção... Os dispêndios em odontologia representam algo perto de $0,16 \%$ do PIB Nacional e 3,5\% de todos os gastos em saúde (5\% na área privada e 2,6\% na área püblica)".

Apesar de ser registrada uma tendência preventiva em ambos os setores, sendo esta mais evidente no setor privado, CORDÓN e GARRAFA ${ }^{16}$ (1991) denunciam que na verdade, atualmente o país está passando por um modismo preventivista. Para eles, "o preventivismo surgiulu como uma ação ideológica e mercantilista, que esconde a essência do problema de saúde bucal e empurra a sociedade para o consumo de medidas individuais e inacessiveis, que não resolvem os problemas 
coletivos..., ou seja, pessoas e grupos de pessoas ligadas direta ou indiretamente ao aparato mercadológico lucrativo, tentam reduzir a prevenção - que significa uma verdadeira filosofia de ação e trabalho odontológico - a um simples ato técnico. Vulgarizando-se em ato técnico, a prevenção torna-se mercadoria e portanto, dependente do processo de compra e venda, acessivel, mais uma vez, a menos de $10 \%$ da população brasileira e inacessivel à esmagadora maioria dos trabalhadores e suas familias".

Os autores comentam, ainda, que "o preventivismo permeia especialmente as clinicas privadas, instaurando os seguros saúde, privilegiando certos grupos de crianças de alto poder aquisitivo, com algumas medidas preventivas, sem considerar a globalidade do ser humano e, sobretudo, sem considerar as consequências deste privilegiamento em toda sociedade. ...o discurso preventivista teve influências, também, nos órgãos públicos que em diferentes momentos adotaram o bochecho com flúor, ou o selante, ou o flúor-gel com moldeiras, ou a escovação com creme dental e outras medidas, sem discuti-las, convenientemente, impondo programas verticais, sem continuidade e com enormes e irresponsáveis gastos públicos, sem impacto social visivel ou previsivel". Diante do caótico panorama apresentado, onde fica evidente que tanto o modelo de prática hegemômico, como a precária cobertura assistencial, os escassos recursos governamentais destinados ao setor público, o modismo preventivista e as politicas do setor, constituem-se, também, em fatores que 
contribuem para acentuar o acesso desigual aos serviços e bens de consumo odontológicos, e consequentemente, para ampliar as desigualdades nas condições de saúde bucal de toda a população brasileira.

Pensando na criança pequena e suas familias, sujeito deste estudo, especialmente as das classes populares, a análise das políticas de saúde bucal e da prática odontológica sugere que são pequenas as possibilidades destas últimas terem atendidas as suas necessidades odontológicas. Os mesmos dados permitem prever más condições de saúde bucal para estas crianças das classes populares, na idade adulta, caso não seja possível fazer algo para reverter a situação.

- documento do Ministério da saúde, citado anteriormente, não faz referência às crianças pequenas, demonstrando que os organismos responsáveis pela promoção de saúde bucal das crianças pequenas não tem priorizado este grupo etário.

Percebe-se que não houve referências a elas no documento do Ministério da Saúde, citado anteriormente.

E fato conhecido que, historicamente, no Brasil, as políticas de saúde bucal têm sido orientadas de forma que a maioria dos programas implementados contemplem, quase que exclusivamente, crianças em idade escolar, havendo nesses o predomínio de ações curativas voltadas para a faixa etária de 6 a 12 anos de idade, posteriormente ampliada até os 14 anos. Sabe-se, também, que recentemente, em 1988, a Divisão Nacional de Saúde Bucal do Ministério da saúde 55 , 
organismo central de coordenação do setor, aprovou a Politica Nacional de Saúde Bucal. Esta, por consenso de várias entidades de Saúde Pública e de representações profissionais brasileiras, estabeleceu as seguintes prioridades quanto a grupos populacionais: em primeiro lugar, crianças entre 6 e 12 anos; em segundo, a faixa etária de 13 a 19 anos; em terceiro, crianças de 2 a 5 anos $e$, finalmente, os adultos.

Ao analisarmos criticamente estas prioridades, o que se percebe é que está havendo uma reprodução de critérios, que tem sido demonstrado serem ineficazes para a melhoria do quadro de saúde bucal da população.

Apesar de, no discurso oficial, já haver uma certa preocupação com a população nas idades entre 2 a 5 anos, esta permanece incipiente, pois como visto, esta faixa etária é colocada em um terceiro plano de prioridades.

Por outro lado, o que se observa na prática, são reflexos da política estabelecida. Os programas locais continuam centralizando suas ações, destinando-as a escolares, permanecendo as necessidades odontológicas e a atenção à saúde bucal dos pré-escolares totalmente descobertas.

Como já comentamos, a situação torna-se perversa ao nos reportarmos às crianças entre 0 a 2 anos de idade, pois foram simplesmente ignoradas pelas autoridades do setor odontológico.

Este abandono, para nós, causa estranheza, pois a adoção de ações educativas e preventivas desde os primeiros 
anos de vida é considerada, por um número significativo de profissionais das diversas áreas de saúde, como medida vantajosa e oportuna para favorecer o desenvolvimento de habilidades e hábitos relacionados à promoção de saúde dos individuos.

Temos como exemplo, as politicas médicas que priorizam a saúde materno-infantil, sendo que no setor pediátrico é dada ênfase preventiva, principalmente, nos dois primeiros anos de vida da criança (TAVAREs ${ }^{78}, 1990$ ).

Maior exemplo, ainda, encontramos no sucesso obtido pelo conjunto dos paises industrializados (com exceção do Japão), no controle da doença cárie, onde têm sido observadas porcentagens significativas de crianças "livres de cárie". Esta situação, tem sido conquistada através de políticas que priorizam os cuidados com a saúde bucal desde o nascimento, sendo que nos primeiros anos de vida da criança, além dos procedimentos preventivos aplicados, há concentração de ações educativas dirigidas aos pais, como, as orientações fornecidas às mães, durante as consultas pré-natais.

Além disso, a exclusão de crianças pertencentes a esta faixa etária é contrária aos resultados extraídos da $1^{a}$ Conferência Nacional de Saúde Bucal15 (1986). Nesta, após a discussão da problemática de saúde bucal por diversos segmentos da população e da categoria odontológica, com relação ao sub-tema prioridades mínimas a serem garantidas na formulação de um Plano Nacional de saúde Bucal, as seguintes foram eleitas, em ordem de prioridade: atendimento à faixa de 
0 a 14 anos de idade; atendimento a gestantes; atendimento do adulto.

os fatos aqui colocados nos permitem afirmar o seguinte:

- As autoridades brasileiras, que têm sido responsáveis pelas polfticas de saúde bucal, consideram a atuação em relação às crianças pequena não são relevante.

- A situação odontológica do brasileiro adulto vem demonstrando que os critérios utilizados para priorizar a atenção a outras faixas etárias não têm garantido melhorias de saúde bucal para estas.

- Será que não lhes ocorre que priorizar a criança de mais de seis anos de idade significa uma perda? se o cuidado por parte dos órgãos oficiais começar a partir dos seis anos, as crianças especialmente as das classes populares, que não dispōe de outros recursos, vão perder parte de sua oportunidade de ter saúde bucal, não somente em relação à preservação de seus dentes, mas em relação à aquisição de hábitos e habilidades apropriados para administrar, posteriormente, os cuidados de saúde bucal.

Estas politicas de saúde bucal que não priorizam as crianças pequenas, tem tido outros efeitos negativos para esta faixa etária. Tem tido réflexos na formação do dentista, alienando-o em relação à gestação e aos cuidados nos primeiros anos de vida. Além disso, a filosofia hegemônica 
que permeia estas politicas, tem tido consequencias no cotidiano do trabalho dos profissionais dentistas, mais preocupados em curar e lucrar, que promover a saúde bucal, através de ações preventivas e curativas.

Todos estes dados nos permitem concluir que a situação atual e possibilidades futuras de promoção da saúde bucal, mais especificamente das crianças pequenas, configuram-se em um quadro de extrema gravidade, constituindo-se em um problema que merece muita atenção.

3. Participação da mãe nos cuidados de saúde bucal da criança pequena.

Em vários campos de estudo é inegável a importância da figura materna para o processo de desenvolvimento do indivíduo, principalmente no-período que envolve a vida intra-uterina e seus primeiros anos de vida.

Tendo como pressuposto básico a compreensão dos diversos niveis de determinação envolvidos no processo saúdedoença bucal infantil, a título de ilustração, citamos a seguir alguns autores que ressaltam a importância de se tentar entender a questão da participação da mãe na vida da criança.

Encontramos através do enfoque sociológico dado por $\operatorname{GIFFIN}^{27}$ (1991), ao analisar a condição feminina na nossa sociedade que, com a separação espacial das atividades de 
trabalho remunerado, o homem se afasta do domicílio e a mulher é responsabilizada socialmente pela totalidade das tarefas domésticas, como a preparação de alimentos, vestuários, limpeza, socialização, educação e cuidados dos filhos.

Podemos acrescentar às consideraçōes da autora que, - desempenho das tarefas que "competem à mulher" se dá de acordo com condiçōes objetivas de existência, definidas por sua condição de classe. 0 que é reafirmado por oLIVEIRA 60 (1990), quando diz que "à criança e sua família é reservado um espaço de vida, onde condições como as de renda familiar, de moradia, de escolaridade, além de uma maneira peculiar de representar o mundo são reproduzidas e especificadas".

$$
\text { Caminhando em outra direção, extraímos }
$$

conhecimentos da psicanálise através de NEUMANN ${ }^{55}$ (1991), ao abordar as importantes influências exercidas pela mãe no processo de enculturação da criança. Segundo ele, ao nascimento da criança é estabelecida uma forte relação da criança com a mãe, "onde a criança vai sendo moldada pela cultura humana, uma vez que a mãe vive imersa num coletivo cultural, cujos valores e linguagem influenciam, inconscientemente, mas de modo efetivo, o desenvolvimento da criança".

A criança no seu processo de enculturação e socialização recebe influências dos valores e normas transmitidos e incorporados pela mãe, que são os valores dominantes, que conduzem a divisão da sociedade em classes, 
onde a relação entre os indivíduos é ordenada pelo poder inerente a suas posiçōes na estrutura social (OLIVEIRA ${ }^{60}$, $1990)$.

Podemos pressupor que partir da leitura destes autores, que o tipo de cuidado dado pela mãe à criança pequena, com relação à saúde bucal tem relação direta com sua cultura e inserção social, as quais exercem importantes influências sobre seus conhecimentos, atitudes e práticas ao tratar as questões de saúde própria e de seus filhos.

A mãe participa do processo de controle da saúde bucal do filho pequeno com valores culturais, experiências com serviços odontológicos, conhecimentos obtidos e atitudes formadas no contato com profissionais da área, professores das escolas, informações obtidas através dos meios de comunicação de massa e a própria vivência tratando a criança desde o nascimento. Ela possui o que poderíamos denominar de saber odontológico popular ou cultura odontológica própria.

Refletindo sobre a inserção social diferenciada das mães, diante da constatação do estreito vínculo existente entre estas e a saúde bucal de seus filhos menores, ocorremnos novas indagações:

- Se estas integram diferentes grupos sociais; se frequentam e têm contato com diferentes instituições (escolas, meios de comunicação de massa, instituições prestadoras de serviços à comunidade...). Como resultado, quais as 
prováveis diferenças quanto a cultura odontológica destas?

- Desde que conhecido que as mães influenciam de forma definitiva os comportamentos de seus filhos, especialmente dos pequenos, quais os prováveis reflexos destas culturas odontológicas desiguais para o estabelecimento ou não de corretos hábitos alimentares e de higiene; para incorporação ou não da valorização da saúde da boca e para a transmissão ou não, e conseqüente assimilação de conhecimentos sobre como promover e preservar a saúde bucal na primeira infância?

- De modo objetivo, como os profissionais da área especifica têm contribuído para a formação da cultura odontológica das mães? Têm considerado o conhecimento odontológico em nível de senso comum destas? Vêm conduzindo açōes educativas com - propósito de melhorar, tornando mais científico e menos ingênuo o conhecimento odontológico das mães de crianças pequenas?

Primeiramente é importante lembrar que os odontopediatras fazem parte de um sistema de atenção à saúde que privilegia o modelo tecnicista, autoritário, onde há pouco espaço para a educação em saúde. A tarefa de educar as crianças e suas familias sobre o processo saúde-doença continua a ser considerada como atividade secundária; a ponto das mães se declararem insatisfeitas com as explicaçōes que recebem, achando-as insuficientes e inadequadas 90 . 
Apesar de o sistema ser autoritário e dificultar a participação da mãe no processo de atenção à saúde da criança, há profissionais comprometidos com uma postura de educação de seus clientes.

No entanto, o confronto entre o "saber odontológico popular"que a mãe possui e. o "saber técnico-científico"nem sempre tem resultado em comportamentos positivos de saúde.

Sobre isso, CORDón e GARRAFA ${ }^{16}$ (1991) afirmam que "o processo educativo em saúde bucal tem sido executado empiricamente, sem o conhecimento mais aprofundado dos seus verdadeiros alcances e inter-conexões, especialmente da cultura, do saber popular e das técnicas adequadas (modelo pedagógico) para sua realização".

- modelo educacional que, tradicionalmente, vem sendo desenvolvido pelos dentistas deriva do modelo médico de educação em saúde que "determina o que o paciente/público nāo está fazendo "corretamente", e trata isto com repetidas tentativas para alterar o comportamento, sem a participação do paciente nesse processo. Esta proposta, culpa a vitima por estar doente. Usualmente, concede um estreito enfoque à responsabilidade individual, de acordo com a definição do profissional sobre comportamentos apropriados e especificações sobre quem é responsável pelo que. (FRAZIER ${ }^{24}$, 1992).

Ao analisar a história das práticas de Educação em Saúde no Brasil, OSHIRO ${ }^{61}$ (1988) apontou para o fato de que, na maior parte do tempo e nas mais variadas instituições que 
foram criadas para desenvolver a Educação em Saúde, o projeto educativo para a saúde não se deslocava do projeto hegemônico da Medicina, constituindo-se como um conjunto de práticas autoritárias, normalizadoras e disciplinadoras de condutas.

No caso especifico da odontopediatria, a criança pequena só pode ser vista, ouvida, cuidada e orientada por intermédio da mãe. Tanto que, quase se pode dizer, que o objeto de comunicação do profissional é a mãe da criança pequena. Dentro desta especialidade, as ações educativas que, tradicionalmente, vem sendo desenvolvidas não fogem à regra, assemelhando-se, portanto, àquelas do setor médicopediátrico.

Os odontopediatras, como os pediatras, sob o ponto de vista de WESTPHAL ${ }^{90}$ (1992), têm desconsiderado que além da educação em saúde particular, as pessoas passam por um processo de educação num sentido amplo, que é algo contínuo, informal, que tendo início no seio da família continua durante toda vida, como parte do processo de socialização e enculturação. Este ocorre de forma consciente ou inconsciente nos contatos formais ou informais dos individuos entre si, como membros dos grupos sociais dos quais participam ou nas instituiçōes que frequentam ou têm contatos.

Para a autora supracitada, "O resultado desse processo contínuo de educação em geral e de educação em saúde em particular é bastante diferente de pessoa a pessoa e principalmente entre o profissional de saúde e o cliente leigo, mais ainda se forem de classes sociais diferentes. Se 
nos contatos profissional de saúde-cliente, pediatra-mãe estes fatos forem ignorados, certamente dificuldades ocorrerão. A orientação durante a consulta precisa ser vista como parte de um processo educativo maior, que já foi iniciado muitos anos antes daquele momento e que continuará independente de retornos do cliente. A mãe na frente do pediatra não é uma tábua rasa. Possui um conhecimento empirico obtido através de seus contatos com a familia, com a medicina oficial, com a medicina popular e com a própria vivência tratando a criança desde o nascimento. Se o pediatra se propuser a orientar pensando em transmitir conceitos, mudar hábitos e costumes sem envolver a māe nas decisōes, terá grande possibilidade de fracassar".

Concordamos com WESTPHAL, que os pediatras tanto quanto os odontopediatras, no geral quer consciente ou inconscientemente é isso que fazem. "Sentem-se investidos do poder que o saber lhes confere, pensando estarem resolvendo a doença a partir do momento que vencem a ignorância do cliente. Então, muitas vezes, por exemplo, quando uma mãe não segue a prescrição, o pediatra vê esta reação como "negligência" ou "incapacidade para executar as instruções recebidas". É dificil que alguém procure perceber o ponto de vista da mãe, que consiga identificar um questionamento dela, que com os conhecimentos adquiridos pela experiência com a doença no dia a dia, pode achar que a solução prescrita não funciona. As barreiras na comunicação pediatra-māe muitas vezes são decorrentes dos conceitos de autoridade e poder 
introjetados no profissional e na mãe que impedem o diálogo e incapacitam o cliente a perguntar ou até opinar. o trabalho educativo se assim feito, unilateralmente, resume-se a uma transmissão de ordens do pediatra, que pode não ter significado para a mãe e a criança".

o predominio do enfoque biológico ou mesmo biopsiquico à nível de ensino e prática odontopediátrica, com negação do social, é outro aspecto a ser considerado nas barreiras de comunicação profissional-mãe, pois faz surgir entre os profissionais, a idealização de um padrão médio e único de comportamento e desempenho infantil, e a crença na existência de uma criança sadia, independente da classe social a que pertença. Isto leva os profissionais a acreditar que as crianças têm melhor ou pior saúde bucal, não em função de condições sociais, culturais e biológicas favoráveis, mas de acordo com o menor ou maior grau de passividade de suas mães à norma odontológica.

Encontramos no trabalho realizado por BOTAzzo 7 (1989), algumas consideraçōes que se aproximam a estas. Através da análise das falas dos dentistas dos serviços públicos sobre o conhecimento odontológico das pessoas, ○ autor detectou que estas contêm discriminação de classe. Reproduzindo estas falas, estes profissionais acham que, "...as pessoas não sabem da importância dos dentes, como são estruturados, quando nascem, o que acontece quando estão cariados, como fazer prevenção: cumpre informar, orientar, esclarecer sempre. Porém, os resultados desse tipo de 
intervenção são escassos e viciados. O açúcar continua presente na dieta dado as pessoas serem pobres; impossivel recomendar o uso de escova e fio dental - as pessoas são pobres, ou as pessoas é que não se importam consigo mesmas, preferindo consumir outras mercadorias, aos produtos para limpeza bucal..."

No entendimento de BOTAZzO ${ }^{7}$, a Odontologia deseja que a população assuma esse discurso, na medida em que ela própria não pode assumi-lo, sob pena de se desqualificar. "...E preciso, portanto, desqualificar o paciente. É ele que não sabe ou não quer se cuidar, ele é que é pobre, desmotivado, que não dá valor aos seus dentes, que não têm "cultura odontológica". O paciente com seu diagnóstico desqualificado é o paciente mudo, cuja história não pode ser ouvida..."

Concordamos com o autor, quando diz que é preciso mudar esse cenário, que é preciso ouvir as pessoas, pois a "fala" socialmente liberada, permite-nos reconstruir caminhos. Precisamos, portanto, ouvir as mães das crianças pequenas, conhecer a cultura odontológica destas. Este tipo de preocupação vai de encontro às propostas dos movimentos da Educação Popular em Saúde e Planejamento Participante em Saúde, que surgiram na América Latina, em oposição ao modelo tradicional de educação em saúde, o qual embora de forma inconsciente, é adotado na educação odontológica. Os avanços neste sentido tem se conduzido, quando muito, para a pedagogia do condicionamento, por exemplo, condicionando a 
criança a escovar os dentes de acordo com a técnica e nas horas certas.

Os defensores da educação participante, dentre eles, o odontopediatra, têm procurado chamar a atenção dos profissionais de saúde, tradicionalmente, "donos do saber", para o fato de que a necessidade de dividir seu papel ativo com o paciente, tentando não só ensiná-1o, como também aprender com ele, ouvílo e buscar conjuntamente soluçōes adequadas.

Indo de encontro a estas preocupaçōes, encontramos um tipo de abordagem que vem sendo muito explorado por alguns estudiosos. Estes têm investigado os comportamentos de saúde bucal dentro de subgrupos da população, associando-os a caracteristicas culturais e sócio-econômicas. Segundo eles, os resultados destas investigaçōes, são altamente importantes para o planejamento de estratégias educativas e preventivas futuras.

No campo específico da saúde bucal infantil, alguns autores concordam em que as pesquisas realizadas com 0 objetivo de se avaliar a relação entre o modo como as mães lidam com as crianças e o processo saúde-doença bucal das mesmas, tem contribuido com importantes informações para o planejamento de estratégias preventivas e açōes educativas, que se ajustem às reais necessidades da população maternoinfantil14,35,83. Outros, consideram-nas importantes para a avaliação da efetividade das propostas educativas que vêm sendo desenvolvidas $32,33,36,67,68$. 
A contribuição tem sido mais importante nos paises onde a atenção à saúde bucal infantil não segue os padrões técnicos utilizados nos países desenvolvidos, onde a saúde bucal das crianças, especialmente das pequenas, fica sujeita às condições desfavoráveis decorrentes das desigualdades sócio-econômicas, e da consequente expropriação de conhecimentos, o que favorece o desenvolvimento de atitudes e práticas inadequadas das mães com relação aos cuidados bucais dispensados aos filhos.

Através da problematização empreendida sobre o processo saúde-doença bucal infantil, ainda que de forma parcial, podemos ter uma vaga idéia do quão complexa e profunda pode ser a discussão sobre os vários fatores envolvidos em sua determinação.

Tivemos, também, contato com propostas desenvolvidas por alguns países que têm implementado politicas de atenção à saúde, que contemplam o nível macroestrutural, distribuindo mais equitativamente os bens produzidos pela sociedade, melhorando assim, a qualidade de vida da população. Neste nível, têm tido uma preocupação com a redistribuição dos serviços de atendimento odontológico, permitindo o acesso de todos os seguimentos sociais. Em nível das micro-relaçōes, o controle da cárie dentária tem sido feito, através do atendimento, acompanhado de um programa de educação e prevenção, oferecido gratuitamente a todas as crianças desde o nascimento. Com isto, estas sociedades, já possuem uma geração de crianças livres da doença. 
Por outro lado, confrontamo-nos, com a fragilidade em que se encontram as condições e possibilidades de obtenção de saúde bucal das crianças pequenas brasileiras, traduzidas, principalmente, pelos elevados índices de cárie dentária nesta faixa-etária. Identificamos relaçōes deste problema com a não priorização deste segmento odontológico pelos encarregados de elaborar as politicas de saúde bucal no país; com o tipo de formação e modelo de prática profissional hegemônico, de características, essencialmente, curativo biológicas; e com as grandes desigualdades sociais existentes em nosso pais, que determinam um acesso desigual aos serviços e bens de consumo odontológicos.

Como são escassos os trabalhos de pesquisa desenvolvidos, que tem essa população como grupo alvo e que referenciam suas análises na determinação social do processo saúde-doença bucal, fugindo do reducionismo técnicobiológico, resolvemos dar nossa contribuição a partir deste paradigma teórico, estudando esta questão junto à crianças pequenas do município de Maringá, Paraná, pois é neste local que existe uma possibilidade de intervir a nível de planejamento e de ensino odontológico.

Identificamos a importância da participação da mãe na determinação do processo saúde-doença bucal dos bebês e pré-escolares, com a consciência de que esta participação está permeada por todos os demais fatores odontológicos e extra-odontológicos e que acaba por influenciar o padrão de saúde bucal do indivíduo no decorrer de sua vida. 
Partindo do pressuposto de que para o planejamento de qualquer ação educativa em saúde bucal, tendo como população alvo a materno-infantil, um dos primeiros passos a ser dado é a busca do saber odontológico popular construido pelas mães. Saber que, provavelmente, apresentará diferenças em função dos processos sociais em que estas se encontram inseridas, dos contatos que têm com os serviços de saúde, em especial os serviços de saúde bucal, bem como através de outras fontes de informação a esse respeito, o presente trabalho busca dar vez e voz às mulheres que acompanham, enquanto mães, o processo de saúde doença bucal de seus filhos pequenos. 
II - OBJETIVOS 
Tendo em vista os pressupostos e questionamentos levantados, o presente trabalho objetiva:

1. Identificar e interpretar as representaçōes e práticas de mães de crianças pequenas acerca do processo saúde-doença bucal, de acordo com suas inserçōes sociais e o acesso aos serviços de saúde;

2. Identificar as relaçōes existentes entre os dois níveis de conhecimento, "cientifico" e de "senso comum", no entendimento do que seja o processo saúde-doença bucal;

3. Avaliar como este saber à nível de "senso comum", pode estar repercutindo nas atividades e práticas de mães de diferentes inserçōes sociais, com relaçāo à saúde bucal de seus filhos. 
III - METODOLOGIA 


\section{Opção Metodológica}

A opção pela utilização da metodologia do tipo "survey populacional" (utilizada em Ciências sociais), pareceu-nos a mais adequada para empreendermos a busca do "saber odontológico popular" construido pelas mães, como era nossa intenção e procedermos à análise das repercussōes deste saber em nível de "senso comum", nas suas atitudes e práticas com relação à saúde bucal de seus filhos.

A produção científica brasileira na área odontológica tem, com raras exceções, privilegiado pouco as questões de saúde bucal sob a perspectiva das ciências sociais.

Ao estudar o desenvolvimento histórico da inclusão das Ciências Sociais no campo da saúde, NUNES ${ }^{59}$ (1992) relata que nos anos 60 "a teoria unicausal não podia dar conta de explicar as complexas relaçōes entre as condições de vida da população e suas doenças. Dessa forma, explicações multicausais são buscadas. Somente na segunda metade dos anos 70, os estudos iriam avançar no sentido de entender a determinação social do processo saúde-doença com a utilização de um marco de referência que ultrapassa a explicação multicausal. As Ciências sociais passam a ser utilizadas na análise da organização das práticas de saúde e do processo saúde-doença, estes vistos como fatores históricos e sociais." 
Segundo o autor, no Brasil, é no pós-74 que começa a ocorrer um intenso debate polstico sobre a questão da saúde, que irá articular-se aos movimentos sociais também neste momento, quer através das associaçōes de bairros, dos movimentos das comunidades eclesiais de base e dos movimentos dos profissionais de saúde: Esses movimentos, além de seu carater reivindicatório, também atuaram no sentido de provocar entre os pesquisadores novos estudos e novas perguntas.

A produção cientıfica das profissões de saúde com ênfase no social, como já comentado, é recente, passando a ter maior expressão na década de 80, principalmente na área médica.

Nas investigaçōes sobre o processo saúde-doença, passa a existir um espaço reservado às questōes teóricas e metodológicas, especialmente de critica ao paradigma que considera a doença como um processo exclusivamente biológico e individual.

Constitui-se para nós um desafio realizarmos o presente estudo procurando combinar métodos de análise qualitativos e quantitativos. Ambos são campos de investigaçāo de alto grau de complexidade e dificuldade, sendo ainda reduzido o número de publicações existentes na área odontológica com esta abordagem e isto aliado à nossa modesta formação acadêmica no que se refere ao campo das Ciências sociaịs e Saúde, ampliou nossa dificuldade. 
Reconhecidas nossas limitaçōes procuramos trabalhar a Saúde Bucal Infantil além das perspectivas técnicobiológicas individuais, próprias da área odontológica. Indo além da causalidade, procuramos enfocar a questão da determinação social inerente ao processo de saúde/doença bucal.

Para que tudo pudesse sair a contento, o "Survey" foi precedido por pequenos estudos exploratórios, que serão relatados ao abordarmos a coleta de dados.

2. Caracterizaçāo da área de estudo

\section{o Município de Maringá}

A partir do progresso da colonização agrícola de todo o norte do paraná no ciclo cafeeiro, em 10 de maio de 1947, a Companhia de Melhoramentos do Norte do Paraná, fundou Maringá.

Possuindo solos de alta fertilidade, constituídos por terras roxas, com clima e relevo favoráveis às atividades agrícolas, a característica principal da região é o estreito vínculo de sua economia com o setor agropecuário.

A história de seu desenvolvimento é comum a várias cidades do Paraná, a explicar-se pela profunda crise que modificou as relaçōes de trabalho no campo e trouxe para as cidades, rápida e progressivamente grandes contingentes de população rural ${ }^{44}$. 
A extensão territorial do município é de $473.064 .190 \mathrm{~m}^{2}$, sendo $128.260 .000 \mathrm{~m}^{2}$ correspondentes à área urbana ${ }^{38}$.

Maringá situa-se ao noroeste do Estado do Paraná, sendo sede da microrregião* composta pelos seguintes municipios: Atalaia, Doutor Camargo, Florai, Floresta, Itambé, Ivatuva, Mandaguaçu, Mandaguari, Marialva, Ourizona, Paiçandu, são Jorge do Ivar, Sarandi e Uniflor.

\subsection{Aspectos demográficos}

Maringá tem, segundo o $\operatorname{IBGE}^{75}$ (1991), a população total de 238.237 habitantes, dos quais aproximadamente $98 \%$ concentram-se em áreas urbanas. Seu padrão de distribuição populacional atual, que caracteriza-se pelo esvaziamento da área rural, confronta-se com o do Estado do Paraná, onde apesar de haver a predominância da concentração urbana $(70,7 \%)$, apresenta o percentual expressivo de $29,3 \%$ dos habitantes ocupando áreas rurais 46 .

* Microrregião: com a finalidade de melhorar a administração dos estados brasileiros, o IBGE agrupou os municípios que apresentam clima, relevo, vegetação $e$ atividades econômicas semelhantes em microrregiōes homogêneas. 


\subsection{Aspectos sócio-econômicos}

A agricultura apresenta-se como principal atividade do setor primário, tendo como produtos principais a soja e o trigo, que ocupam cerca de $90 \%$ da área e respondem a cerca de 75\% do valor da produção das lavouras. o município é também centro abatedor de bovinos, suinos e aves.

Maringá conta com 23 Parques Industriais, onde destacam-se os setores de agro-indústria, alimentação, metalmecânico e confecçōes.

- setor terciário, principal fonte geradora de empregos, absorve $69,44 \%$ da População Economicamente Ativa PEA) do município, seguido dos setores secundário com a absorção de cerca de $22,11 \%$ e do primário concentrando $8,45 \%$ da PEA.

\section{Renda}

A população em idade produtiva, segundo ○ IPARDES perfaz 163.185 habitantes, dos quais $48,4 \%$ são homens e $51,6 \%$ são mulheres, sendo que desses, respectivamente, $37,88 \%$ e $18,83 \%$ pertencem à população economicamente ativa.

Dentre a população que economicamente ativa, verifica-se que $76,12 \%$ têm redimento mensal até 3 (três) salários mínimos, sendo que a concentração maior situa-se na faixa de 1 a 1,5 salários mínimos. Deduz-se que o conjunto da população que pode ser considerada como de baixa renda é significativo. 


\section{Saneamento básico}

Quanto à infra-estrutura referente a saneamento básico, Maringá conta com uma rede de abastecimento de água que atinge $95 \%$ da população urbana.

A água é fluoretada desde 1967, sendo o controle do teor de fluor, executado diariamente, pela divisão regional de manutenção da estação de tratamento de água. Este varia, entre 0,9 e $10 \mathrm{ppm}$.

o esgoto coletado é tratado através de duas estaçōes (lagoas de estabilização) beneficiando aproximadamente $44,4 \%$ da população urbana, podendo-se constatar um déficit de $35,6 \%$, se considerado como parâmetro de eficiência $80 \%$ da população urbana servida, segundo a organização Mundial da saúde. o serviço de coleta e disposição final do 1 ixo atende cerca de $95 \%$ da áreas habitadas da cidade ${ }^{75}$.

\subsection{Aspectos epidemiológicos}

\section{A mortalidade infantil}

Maringá apresenta uma taxa de mortalidade infantil diferenciada, frente à realidade nacional, (22.19 por 1000 n.v.). Esta é baixa quando comparada aos coeficientes do Estado (36.98 por 1000 n.v.) e do Brasil (48.16 por 1000 n.v.) 
Segundo souzA 75 (1992) a explicação para este fato encontra-se no campo econômico. O Município conta com uma agropecuária de expressão, o comércio e a indústria são capazes de absorver inclusive parcela de trabalhadores de municípios circunvizinhos. Certamente este potencial econômico contribui de forma favorável à geração de "gastos realizados em educaçāo, saúde, moradia, elementos necessários à vida coletiva, que são consequentes às possibilidades de captação de recursos a serem geridos pelo setor público. Para a autora, bens e serviços assim oferecidos à população maringaense também devem estar influindo favorávelmente na qualidade de vida".

\section{$\underline{\text { A Saúde Bucal }}$}

Em 1991, a Secretaria Municipal de Saúde realizou o I Levantamento Epidemiológico em odontologia do Município de Maringá 47 .

As informaçōes contidas no estudo são as únicas disponiveis para tentarmos uma aproximação à situação de saúde bucal da população maringaense. são citadas com reservas, pois a coleta dos dados foi alvo de várias críticas quanto à execução, bem como a análise e apresentação dos mesmos. 
- Indice CPOD médio* encontrado por faixas etárias foi: 0,6 (6 anos); 2,6 (9 anos); 5,0 (12 anos), 8,4 (15-19 anos); 14,6 (35-44 anos). e 14,0 (50 - 59 anos). Estes valores foram inferiores àqueles do Levantamento Nacional, tidos como referência.

Ao se proceder a análise pelos componentes do Indice, a situação encontrada foi a seguinte: para a faixa entre 6 a 12 anos de idade, 44,33\% dos dentes examinados estavam atacados pela cárie, 1,24\% com extração indicada, $2,01 \%$ já haviam sido extraídos e $52,42 \%$ estavam obturados.

Por outro lado, na faixa entre 50-59 anos de idade, - aumento do Indice ocorreu em função direta do componente extraido, este representando $80 \%$ do valor global.

Quanto à utilização de prótese total, as porcentagens foram as seguintes: $9.09 \%$ e $40.0 \%$ nas faixas etárias 35 a 44 e 50 a 58 anos de idade, respectivamente. Este aumento do número de dentaduras com a idade está diretamente relacionado com o alto número de extrações já referido nestes grupos.

- levantamento questionou a porcentagem da população que utilizava dentista particular segundo o grupo etário. Constatou-se que 0 acesso ao dentista particular aumentou, gradualmente, com a idade. A equipe de pesquisa sugeriu que este fato deve ter ocorrido devido aos serviços públicos terem como prioridade o atendimento odontológico às

* CPOD médio: significa o número total de dentes cariados, perdidos e obturados, dividido pelo número de indivíduos examinados. 
crianças em idade escolar (6 a 14 anos).

os dados demonstraram que os percentuais da população que procuraram o dentista particular foram, $28,76 \%$ dos 6 aos 12 anos; $44,23 \%$ dos 15 aos 19 anos; 51,51\% dos 35 aos 44 anos e $60,00 \%$ dos 50 aos 59 anos

Através dos resultados desta pesquisa, podemos inferir que a situação de saúde bucal da população maringaense acompanha o mesmo quadro caótico nacional, porém, em menores proporções. E que entre os prováveis fatores determinantes da mesma, a utilização pelo município do modelo de prática odontológica tradicional hegemônico, ocupa um papel importante.

- município conta com a ação de 360 dentistas, segundo informaçōes do Conselho Regional de Odontologia do Paraná.

\section{Servicos de Saúde}

Maringá conta com 1 Centro Regional de Especialidades (congrega profissionais da Secretaria de Saúde e do INAMPS), 12 hospitais (11 privados e 1 público Hospital Universitário) e a nível municipal, a rede básica de serviços é constituída por 27 unidades de saúde. A distribuição espacial das unidades atende tanto as regiões mais centrais quanto as mais periféricas, no entanto, ainda existem áreas sem atendimento. As maiores carências são 
encontradas nos bairros novos, os quais acham-se desprovidos destas unidades 38 .

Os recursos humanos do setor odontológico, na rede pública, são assim distriburdos: Dentistas (79), Técnicos de Higiene Dental-THD (16) e Atendentes de Consultório Dentário$\operatorname{ACD}(87)$.

os serviços de saúde bucal são ofertados em todas as unidades da Rede Ambulatorial. Além desta atuação, a Secretaria Municipal de saúde dispōe de três consultórios, que percorrem as creches prestando atendimento clínico e duas clínicas móveis que fazem rodizio nas escolas municipais, rurais e urbanas.

- atendimento odontológico é ofertado a nível preventivo e curativo para gestantes e crianças de 0 (zero) a 14 anos, sendo faixa prioritária a de 6 a 14 anos de idade. Aos adultos é oferecido tratamento de urgência em 4 unidades de saúde, que contam com $\circ 3^{0}$ turno de atendimento ao público.

\section{Delimitação do Universo de Estudo}

De acordo com o explicitado no projeto de pesquisa, a população alvo deste estudo seria constituída por mães de crianças menores de 5 anos de idade. Para atingirmos os objetivos colocados era necessário que estes atores sociais tivessem diferentes inserçōes sociais.

Diante desta necessidade nós deparamos com o 
problema sobre o local ideal para realização da investigação: Pré-escolas, Berçários, Creches?

Em pré-escolas, muito provavelmente não atingiriamos a faixa etária pretendida, pois a maior frequência a estas instituições é de crianças acima de 4 anos de idade. Por outro lado, nas creches não encontraríamos as mães de classe social alta, além do que, não terímos garantida a presença de crianças de todos os grupos de idade. sabe-se que nos berçários, a procura é feita por mães de inserção social mais elevada.

Após analisar várias sugestōes, resolvemos trabalhar com um "Dia de vacinação em massa".

Segundo GUERRA 80 (1991) parece estar se estabelecendo no Brasil uma "cultura de vacinação". o comparecimento de mães nos "Dias Nacionais de Vacinação", instituídos a partir de 1980 com o objetivo de se erradicar a poliomielite, tem sido acima de $90 \%$.

Além do comparecimento maciço de mães, outro ponto importante é que estas campanhas são dirigidas a crianças com até 5 anos de idade.

Somado a estes aspectos, o fator decisivo para escolha de nosso universo de estudo foi o fato de que ao trabalharmos com este "dia", poderíamos através de um procedimento de amostragem garantir a representatividade dos resultados da pesquisa, extendendo-os a todas as mães de crianças menores de 5 anos de idade do Município de Maringá.

Esta campanha ocorre duas vezes ao ano (duas 
fases). É realizada em um único dia, no periodo das 8 às 17 horas. As datas, definidas pelo Ministério da saúde e os locais, pré-fixados pelo Centro de Vigilância Epidemiológica das Secretarias Municipais de Saúde, são amplamente divulgados à população através dos meios de comunicação em massa.

- presente estudo, portanto, foi realizado na primeira fase da Campanha de Multi-Vacinação de 1993, oportunidade ideal encontrada para se estabelecer a interação social com sua população-alvo : mães de crianças menores de 5 anos de idade.

A área de pesquisa foi estendida aos 60 postos fixos de vacinação do município de Maringá (abrangendo as regiōes urbana e rural), que foram instalados em unidades de saúde, escolas municipais e estaduais, creches, bancos e bloqueios rodoviários.

4. Procedimentos de amostragem

Neste estudo, a unidade de observação e análise constituiu-se na mãe de toda criança vacinada.

Para definição do tamanho da amostra utilizamos como parâmetros os dados da Secretaria Municipal de Saúde do Município de Maringá referentes à campanha de vacinação, anterior à pesquisa. Através destes, foi possível conhecer o número de crianças que foram vacinadas em cada um dos sessenta postos, como também, a projeção de comparecimento 
esperada para o dia da investigação.

Por questōes de facilidade operacional como, o número de entrevistadores disponíveis, o tempo requerido para realização de cada entrevista e a própria dinâmica de uma campanha como esta, estabeleceu-se que 600 mães seriam entrevistadas, sendo 10 em cada posto de vacinação.

$\bar{A}$ partir da primeira entrevista realizada, respeitou-se o intervalo amostral, definido em cada local de vacinação pela divisão do número estimado de comparecimento de crianças por 10 . Fixou-se um erro ou desvio de amostragem igual a no máximo $10 \%$.

Após a realização da pesquisa o número de mães, cujas entrevistas estão sendo objeto de análise caiu para 554. Este decréscimo foi consequiente ao comparecimento reduzido nos postos situados em bloqueios rodoviários, a recusa de algumas mães em prosseguir a entrevista e a eliminação de formulários, nos quais constava a presença de filhos com idades acima de 6 anos.

5. coleta de dados

A entrevista semi-estruturada foi a técnica escolhida para atender aos nossos objetivos. Um instrumento foi elaborado contendo perguntas fechadas e abertas. Nas fechadas, a resposta da informante não estava condicionada a multiplicidade de opçōes apresentadas pelo entrevistador. Ao 
contrário, nestas questões, a fala foi livre, sendo relacionada pelo entrevistador a uma das categorias de resposta estabelecidas em estudos exploratórios prévios. Com as abertas, buscou-se maior aprofundamento de alguns pontos. de interesse, permitindo-se às mães expressarem-se livremente ao respondê-las, sendo responsabilidade do entrevistador transcrever literalmente a fala das mães.

os dados obtidos através desta técnica foram de natureza objetiva e subjetiva, isto é, atitudes, valores e opiniōes.

Para a definição do conteúdo do formulário, procedeu-se a várias etapas exploratórias, conforme mencionamos anteriomente.

Na primeira, através de conversas com mães que levavam seus filhos pequenos ao atendimento odontopediátrico do Curso de Odontologia da Universidade Estadual de Maringá procurou-se conhecer os temas de maior preocupaçāo e dúvidas com relação a saúde bucal das crianças. O atendimento odontológico neste serviço é ofertado às camadas populares.

$$
\text { Procedeu-se similarmente em um consultório }
$$
particular odontopediátrico, cuja clientela é constituída por indivíduos das altas esferas sociais.

As questões levantadas pelas mães na etapa anterior serviram como base para elaboração de um instrumento em "caráter preliminar", contendo apenas perguntas abertas, que foi aplicado na segunda etapa exploratória.

Apesar das perguntas serem especificas, foi mantido 
- mesmo clima de liberdade assegurado na primeira etapa, com a isenção de qualquer "dirigismo".

Foram realizadas 70 entrevistas na creche da Universidade Estadual de Maringá. Este equipamento social é destinado a crianças entre 0 a 2 anos de idade, filhos de professoras e funcionárias.

Como resultado desta fase, obteve-se praticamente todas as informações pretendidas. Pode-se, também, eliminar as informações não pertinentes ao objeto da pesquisa ou de pequena relevância para a mesma.

Diante da grande massa de informações obtidas, houve a necessidade de reduzi-la, a fim de torná-la operacional. As questões foram revistas e estruturadas, permanecendo abertas aquelas de interesse. Pode-se chegar a um formulário com perguntas mais objetivas e adequadas à finalidade do presente estudo.

o pré-teste desta investigação foi realizado em um dia de vacinação em massa, onde entrevistou-se 50 mães. Nesta terceira etapa, além de buscar-se o ajuste do instrumento de coleta de dados, procurou-se conhecer a "dinâmica" deste dia. Houve a preocupação, entre outras, com a receptividade das entrevistas, com a sua duração e o espaço ideal para se promover a interação social entre o entrevistador e a mãe. Repitiu-se a revisão do questionário, inclusive no que dizia respeito à compreensão de sua redação. 
Pela análise das respostas obtidas no pré-teste, pôde-se proceder à codificação e categorização de seus conteudos, transformando algumas questões abertas em estruturadas, visando tornar mais rápidos e eficazes os. procedimentos definitivos de coleta, tratamento e análise dos dados (ANEXO A) .

A quinta etapa constituiu-se no momento definitivo de coleta dos dados, onde o conteúdo das entrevistas visava apreender as características sócio-econômico-demográficas dos sujeitos de investigação, além de identificar suas representaçōes, atitudes e práticas com relação a questōes de saúde bucal: próprias e de seus filhos.

\section{Levantamento dos dados}

Previamente à coleta dos dados entramos em contato com o setor de Vigilância Epidemiológica da secretaria Municipal de Saúde de Maringá. Explicamos a importância e os objetivos desta pesquisa à coordenação de vacinação e solicitamos sua autorização e colaboração para podermos atuar neste "dia".

obtida a permissão, participamos das reuniões de planejamento da campanha, oportunidade em que pudemos explicar às equipes de vacinaçāo o motivo da presença dos entrevistadores neste dia, assegurando-lhes que não haveria comprometimento na rotina de vacinação. 
Para o processo de coleta de dados, houve a participação de 48, alunos do curso de odontologia da Universidade Estadual de Maringá e de 12 alunos do curso de Técnico em Higiene Dental promovido pela Secretaria Municipal de Saúde de Maringá. Coube a estes a aplicação do formulário, registrando, simultaneamente, as respostas no próprio formulário.

Para execução destes procedimentos os entrevistadores foram previamente treinados e calibrados.

o levantamento contou, também, com a colaboração de 5 docentes da área odontológica que auxiliaram na supervisão de todo o processo:

\section{Variáveis de Estudo}

o trabalho empirico-analitico incidiu inicialmente sobre dados relativos às mães e suas famílias, possibilitando uma caracterização mais completa das mesmas e das condiçōes em que vivem.

As variáveis, em relação às condições sócioeconômico-demográficas, incluídas no estudo fọam: idade, procedência (rural ou urbana), local de nascimento, tempo de residência no município, estado civil e marital, escolaridade, ocupação, renda "per capita", número total de filhos, número de filhos menores de 5 anos de idade, sexo e idade dos filhos menores de 5 anos de idade, local de permanência dos filhos menores durante $\circ$ dia e pessoa 
responsável pelos cuidados dos filhos menores.

A codificação das questões referentes às condições sócio-econômicas, permitiu que o conjunto delas definisse a "situação de classe" das entrevistadas. A análise destas questōes e a construção das classes sociais requereu um trabalho cuidadoso e um bom dominio dos conceitos relacionados à teoria de "classes sociais".

Utilizou-se como elemento referenciador para operacionalização do conceito de classe social, o esquema proposto por BRONFMAN e TUIRAN ${ }^{11}$, adaptado por LOMBARDI e $\operatorname{col} .^{42}$ (1988).

Para análise das representações, atitudes e práticas das mães com relação a saúde bucal as variáveis selecionadas foram reunidas nos seguintes grupos temáticos:

1. ALEITAMENTO: hábito de mamadeira noturna, prática materna de introdução de substâncias à mamadeira, substâncias a ela acrescidas e motivo do acréscimo.

2. CONHECIMENTO SOBRE DENTES DECÍDUOS E PERMANENTES: Número e função dos dentes decíduos e número total dos dentes permanentes.

3. HÁBITOS DE HIGIENE BUCAL DOS FILHOS: Época da primeira limpeza dos dentes, fonte de orientação materna sobre os primeiros cuidados com higiene bucal, número de vezes e horários em que as crianças devem escovar seus dentes. 
4. HÁBITOS ALIMENTARES RELACIONADOS AOS FILHOS: hábito de "beliscar" e tipo de alimento ingerido entre refeições, oferta de alimentos entre refeições aos filhos, opinião materna sobre o hábito de seus filhos de "beliscar" entre as refeições, prática materna para remoção do hábito de ""beliscar" entre refeiçōes dos filhos.

5. UTILIZAÇÃO DOS SERVIÇOS ODONTOLÓGICOS: Primeira visita dos filhos ao dentista (idade e motivo) e motivo habitual de procura ao dentista para os filhos.

6. CONHECIMENTO SOBRE FLUOOR: Contato prévio com informaçōes sobre flúor, fonte de informação, utilidade, utilização pelos filhos e motivo da fluoretação da água de abastecimento público de Maringá.

7. CONHECIMENTO SOBRE DOENÇAS BUCAIS: Doenças bucais mais comuns, conceito e causa da cárie dentária, causa da cárie, avaliação sobre a gravidade da doença, solução do problema e métodos preventivos da cárie.

8. EXPOSIÇÃO DAS MÃES A CONHECIMENTOS ODONTOLÓGICOS PRÉVIOS: Fonte de orientação sobre a prática de escovação de seus próprios dentes, hábito materno de "beliscar" entre as refeiçōes e motivo habitual da procura ao dentista pelas mães. 
Na sua grande maioria, as questōes que compunham o formulário utilizado para as entrevistas eram "fechadas", com códigos pré-estabecidos. Para se proceder à codificação das demais questōes, estas foram, inicialmente, categorizadas, após o que, elaborou-se um manual de codificação.

\section{Processamento e Análise Estatítica}

Para cada questionário preenchido, definiram-se as informações referentes às mães e aos filhos. A base de dados, portanto, constituiu-se de dois arquivos: o arquivo-mães com 554 e o arquivo-filhos com 693 registros.

A composição das amostras (mães e filhos) foi estudada através de distribuição de freqüências univariadas, calculadas para todas as características consideradas no questionário.

Numa segunda fase, separaram-se (para mães e/ou filhos) as informaçōes (variáveis/respostas) cujo interesse do estudo buscava associações com caracteristicas demográficas, sócio-economicas ou comportamentais. Distribuições de freqüências bi-variadas (Tabelas de contingência) e a aplicação do teste de independência para cada variável/resposta isoladamente, geraram a elaboração de um quadro com as possíveis associações entre as mesmas e as caracteristicas já citadas. A partir da análise dos resultados apresentados em cada quadro (X2: qui-quadrado calculado, GL: graus de liberdade, P: nível de significância 
estimado), destacou-se o conjunto de características associado à cada variável resposta, fixando-se $p<=0,05$ como critério preferencial.

A decisão final sobre as associações existentes foi definida pela avaliação de resultados obtidos, através da técnica de análise de regressão logística múltipla, com aplicação do método de máximo-verossimilhança. Para cada variável resposta definiram-se apenas duas categorias de resultados. Assim, a probabilidade de ocorrência da categoria fixada (p) em cada amostra definida pelo cruzamento das caracteristicas selecionadas na segunda fase da análise ( $X_{1}$, $\mathrm{X}_{2}, \ldots . \mathrm{x}_{11}$ ) passou a ser explicada pelo ajuste de uma função linear, na qual logito $(p)=A+B_{1} x_{1}+B_{2} X_{2}+\ldots+B_{11} X_{11}$; sendo os $B_{1}$ parâmetros que serão estimados pelo modelo ajustado.

Os dados foram processados através do CATMOD, procedimento do SAS/STAT para análise de dados categóricos, aproveitando-se os resultados referentes à seleção de efeitos na variação do logito de $p$, representadas sob a forma de quadro de análise de variância.

No presente estudo, levando-se em consideração a facilidade de exposição e interpretação dos resultados, optou-se pela apresentação dos mesmos através de quadros, constituidos por um conjunto de tabelas, fugindo às normas de apresentação tabular. 
- modelo foi considerado adequadamente ajustado, para cada variável resposta, quando o qui-quadrado do residuo apresentou resultado não-significante, ou seja prob>0,05. Em seguida, consideraram-se como caracteristicas associadas aquelas cujos qui-quadrados apresentaram resultados significantes (probabilidade menor ou igual a 0,05), confirmando o seu efeito como fonte de variação para logito de $p$. 
IV - RESULTADOS E DISCUSSÃO 
1. CARACTERÍSTICAS SÓCIO-ECONÔMICO-DEMOGRÁFICAS DA POPULAÇĀo DE ESTUDO

\subsection{As mães}

Dentro da concepção geral que está norteando o desenvolvimento do presente estudo, através das informações colhidas junto às entrevistadas, procuramos, neste primeiro momento, conhecer um pouco mais sobre a realidade das mães de crianças pequenas, residentes no município de Maringá, tanto através de características próprias, como de suas familias, seus modos e condições de vida.

Por ocasião da entrevista, elas apresentavam em sua maioria $(84,5 \%)$ entre 20 a 34 anos de idade. Adicionalmente, havia aquelas muito jovens $(2,9 \%)$ e as com maior maturidade $(11,1 \%)$. A idade média das mães foi 28 anos (TABELA 1).

TABELA 1 - Distribuição das mães segundo a idade

\begin{tabular}{l|rr}
\hline IDADE & Freq & \multicolumn{1}{c}{$\%$} \\
\hline $15-19$ & 16 & $2.9 \%$ \\
$20-24$ & 139 & $25.1 \%$ \\
$25-29$ & 190 & $34.3 \%$ \\
$30-34$ & 139 & $25.1 \%$ \\
$35-39$ & 44 & $7.9 \%$ \\
$40-49$ & 18 & $3.2 \%$ \\
NĂO RESPONDEU & 8 & $1.4 \%$ \\
\hline Total & 554 & $100.0 \%$ \\
\hline
\end{tabular}


Quanto à idade que possuiam ao nascimento do primeiro filho, $61 \%$ das māes disseram encontrar-se na faixa de idade considerada como sendo a mais adequada, seja do ponto de vista fisiológico ou familiar, a de 20 a 29 anos (TABELA 2). Por outro lado, chamou-nos a atenção o percentual significativo de mães adolescentes $(30,3 \%)$, que provavelmente devem ter tido problemas para assumir a gravidez e maternidade como meninas-mulheres e ainda suas responsabilidades, dentre as quais os cuidados adequados dos filhos.

Notamos, também, que uma parcela expressiva das mulheres $(8,3 \%)$, experenciou a maternidade em uma fase mais tardia de suas vidas. Provavelmente, este fato seja consequente à alteração da participaçāo feminina em nossa sociedade onde " "a busca de oportunidade de trabalho, as dificuldades econômicas e a falta de infra-estrutura de apoio aos cuidados às crianças, levam-nas a postergar a prole" $\left(\operatorname{SOUZA}^{75}, 1992\right)$. 
TABELA 2 - Distribuição das mães segundo idade ao nascimento do primeiro filho.

\begin{tabular}{l|rc}
\hline IDADE & Freq & $\%$ \\
\hline $11-19$ & 168 & $30.3 \%$ \\
$20-24$ & 221 & $39.9 \%$ \\
$25-29$ & 117 & $21.1 \%$ \\
$30-42$ & 46 & $8.3 \%$ \\
Nāo respondeu & 2 & $0.4 \%$ \\
\hline Total & 554 & $100.0 \%$ \\
\hline
\end{tabular}

Percebemos entre as entrevistadas, a inexistência das chamadas "grandes proles". Apenas 1,3\% das mães tinham um total de cinco filhos, ao passo que $34,1 \%$ e $46,8 \%$ destas possuiam, respectivamente, dois filhos e filhos únicos (TABELA 3).

As taxas observadas estão de acordo com o declínio da fecundidade verificado no Brasil, nas últimas décadas. Segundo BARROSO ${ }^{5}(1991)$, "Apesar da permanência de uma variação enorme por região, área de residência, idade e nIvel educacional no pais como um todo, a grande maioria das pessoas e dos casais procura limitar o número de filhos, utilizando os meios ao seu alcance". 
Para a autora, as razões que levaram a essa mudança foram, a maciça migração do campo para a cidade, onde as condições de vida tornam dificil a criação de muitos filhos; as próprias relaçōes de trabalho na agricultura se modificaram, restringindo a cultura de subsistência, dificultando o trabalho infantil e encarecendo a alimentação, que passou a ser adquirida no mercado; aumentou o número de mulheres que passaram a trabalhar longe de suas casas, em locais onde não podem levar consigo seus filhos pequenos; permaneceu reduzida a disponibilidade de creches e locais coletivos de cuidado infantil; aumentou a escolaridade e a rede de comunicação de massa, com variadas consequências em diversos níveis e modificaram-se as relações, tanto econômicas como afetivas, entre pais e filhos, na infância e na idade adulta.

No nosso entender, o planejamento familiar executado, de forma consciente ou inconsciente, pelas mães em estudo e seus companheiros reflete, entre outras, a preocupação com a qualidade de vida a ser proporcionada aos filhos. Além do que, temos que considerar que, a presença de um número expressivo de filhos únicos, deve estar vinculada ao fato de serem mulheres jovens, que estão em período fértil, podendo, portanto, optar por ter mais filhos. 
TABELA 3 - Distribuição das mães segundo o número total de filhos

\begin{tabular}{l|rc}
\hline NÚMERO & Freq & $\%$ \\
\hline 1 & 259 & $46.8 \%$ \\
2 & 189 & $34.1 \%$ \\
3 & 78 & $14.1 \%$ \\
4 & 21 & $3.8 \%$ \\
5 & 7 & $1.3 \%$ \\
\hline Total & 554 & $100.0 \%$ \\
\hline
\end{tabular}

Como colocado anteriormente, é nosso interesse particular estudar as características sócio-econômicodemográficas das mães de crianças pequenas, ou seja, bebês e pré-escolares (entre 0 a 5 anos de idade). Para isso, tornase fundamental deixarmos mais explicitos os dados sobre nosso objeto. Assim, ao limitarmos o total de filhos das entrevistadas, às crianças menores de cinco anos de idade, a proporção de mães com apenas um filho aumentou para $76,5 \%$, enquanto que $22,4 \%$ destas tinham dois filhos e apenas $1,1 \%$ três filhos pequenos (TABELA 4). 
TABELA 4 - Distribuição das mães segundo o número de filhos com até 5 anos de idade.

\begin{tabular}{l|rc}
\hline NUMERO & Freq & $\%$ \\
\hline Um & 424 & $76.5 \%$ \\
Dois & 124 & $22.4 \%$ \\
Três & 6 & $1.1 \%$ \\
\hline Total & 554 & $100.0 \%$ \\
\hline
\end{tabular}

Do total das 554 mães, a grande maioria $(73,1 \%)$, nasceu na microrregião de Maringá ou no próprio município; $69,1 \%$ tiveram procedência urbana e uma porcentagem importante destas $(30,9 \%)$ procedência rural. No entanto, por ocasião da entrevista, quase que a totalidade delas pertencia à região urbana e, mais da metade $(65,8 \%)$, residiam em Maringá, há pelo menos 10 anos (ANEXO B).

observamos que a maioria das mães estudadas dividiam suas vidas e responsabilidades com companheiros, sendo $78 \%$ casadas legalmente, e $8,3 \%$ apresentando relacionamentos não oficiais, de duraçāo variada. (TABELA 5) 
TABELA 5 - Distribuição das mães segundo o tipo de união.

\begin{tabular}{l|rc}
\hline UNIĀo & Freq & $\%$ \\
\hline Legal & 430 & $77.6 \%$ \\
Informal & 46 & $8.3 \%$ \\
Sem união & 78 & $14.1 \%$ \\
\hline Total & 554 & $100.0 \%$ \\
\hline
\end{tabular}

As familias possuiam o perfil típico nuclear, sendo compostas em sua maioria $(71,1 \%)$ por 4 membros. Entre as demais, $26,7 \%$ eram constituidas por até 8 pessoas e um número extenso, acima de 9 moradores no domicilio foi observado somente em $2,2 \%$ dos casos (ANEXO B).

Considerando-se que o chefe formal da familia é, em geral, quem a sustenta, a análise desta variável mostrou-nos que para a maior parte das familias (71,5\% dos casos), 0 chefe era o marido/companheiro da entrevistada, sendo poucas mulheres inseridas no mercado de trabalho, que assumiam ou compartilhavam este sustento. (TABELA 6) 
TABELA 6 - Chefia e responsabilidade pelo sustento da familia.

\begin{tabular}{l|rc}
\hline RESPONSVÁLL & Freq & $\%$ \\
\hline Própria mãe & 43 & $7.8 \%$ \\
Marido/companheiro & 396 & $71.5 \%$ \\
Casal & 63 & $11.4 \%$ \\
Pai/Mae entrevistada & 33 & $6.0 \%$ \\
Outras pessoas & 19 & $3.4 \%$ \\
\hline Total & 554 & $100.0 \%$ \\
\hline
\end{tabular}

Constatamos que $37,4 \%$ das mães afirmou possuir ocupação remunerada, ao passo que a maioria (cerca de 53\%) destas assumiu restringir suas atividades aos cuidados do lar (TABELA 7). Entre aquelas que possuiam remuneração em suas ocupações, somente $29,6 \%$ estavam trabalhando de forma regular (ANEXO B).

TABELA 7 - Distribuição das mães segundo a remuneração na ocupação.

\begin{tabular}{l|rc}
\hline OCUPAÇĀO & Freq & $\%$ \\
\hline SIM & 207 & $37.4 \%$ \\
NÃO & 293 & $52.9 \%$ \\
NÃO RESPONDEU & 54 & $9.7 \%$ \\
\hline Total & 554 & $100.0 \%$ \\
\hline
\end{tabular}


A análise da escolaridade, tida como um bom indicador do nível sócio-econômico das populações por oferecer dados precisos, com relação à nossa população de estudo, mostrou-nos proporçōes semelhantes de mães que haviam completado $\circ 1^{\circ}, 2^{\circ}$ e $3^{\circ}$ graus. Porém, a taxa de maior expressão foi encontrada entre as mães alfabetizadas, com poucos anos de estudo $(41,7 \%)$, (TABELA 8 ).

TABELA 8 - Distribuição das mães segundo a escolaridade.

\begin{tabular}{l|rc}
\hline ESCOLARIDADE & Freq. & $\%$ \\
\hline Analfabeto/sabe ler e escrever & 18 & $3.2 \%$ \\
10. Grau incompleto & 231 & $41.7 \%$ \\
10. Grau completo & 75 & $13.5 \%$ \\
20. Grau imcompleto & 38 & $6.9 \%$ \\
20. Grau completo & 88 & $15.9 \%$ \\
30. Grau incompleto & 27 & $4.9 \%$ \\
30. Grau completo & 60 & $10.8 \%$ \\
Não respondeu & 17 & $3.1 \%$ \\
\hline Total & 554 & $100.0 \%$ \\
\hline
\end{tabular}

Os dados demonstram-nos que a população de estudo era heterogênea, com relação ao nível de educação. Se por um lado, encontramos a maior parcela de mães com baixos níveis de escolaridade, houve, também, porcentagens importantes destas que apresentavam os níveis de formação: médio ou superior. 
Além disso, podemos inferir das taxas observadas, que o fato de a grande maioria das mães do estudo possuir baixa escolaridade, provavelmente está associado a uma posição social inferior destas e portanto a condições de vida mais precárias.

Sabe-se que a renda familiar não é tida como um bom indicador sócio-econômico populacional, pois os informantes podem alegar desconhecerem a renda de um ou mais membros da familia. Muitas vezes fornecem dados imprecisos e às vezes, simplesmente, recusam-se a declará-la.

Contudo como esta variável é o indicador de condiçōes sócio-econômicas mais utilizado nas pesquisas odontológicas, obtivemos informações a este respeito, considerando-as como dados complementares na caracterização de nossa população de estudo. A TABELA 9 confirma a's baixas condiçōes econômicas de cerca de $79 \%$ das familias de estudo. Encontrou-se que $37,4 \%$ destas recebiam entre 1 a 3 salários minimos "per capita", sendo a situaçāo mais precária observada entre a maioria das familias $(42,1 \%)$, que ganhava menos de 1 salário mínimo "per capita". Por outro lado, a minoria destas. $(7,6 \%)$ apresentava entre 3 a 5 salários e aproximadamente $3,4 \%$ faziam parte de um grupo privilegiado, em que cada pessoa da familia percebia acima de 5 salários mínimos mensais. 
TABELA 9 - Renda "per capita" em salários mínimos.

\begin{tabular}{l|rc}
\hline RENDA & Freq. & \multicolumn{1}{c}{$\%$} \\
\hline menos de 1 & 233 & $42.1 \%$ \\
1 I-- 3 & 207 & $37.4 \%$ \\
3 I-- 5 & 42 & $7.6 \%$ \\
5 I-- 10 & 16 & $2.9 \%$ \\
10 e & 3 & $0.5 \%$ \\
Não sabe & 28 & $5.0 \%$ \\
Não declarou & 25 & $4.5 \%$ \\
\hline Total & 554 & $100.0 \%$ \\
\hline
\end{tabular}

A utilização do conceito de classe social em estudos de saúde tem sido realizada como uma tentativa de ampliar o entendimento do processo saúde-doença na perspectiva de sua determinação social. Assim, para finalizar a caracterização sócio-econômica dos atores sociais implicados neste estudo, buscamos a inserção destes nas diferentes "situaçōes de classe social".

Como descrito no capitulo da metodologia, ainda que assunto controverso, optou-se nesta pesquisa por uma aproximação ao conceito de classe social, através de sua operacionalizaçāo, utilizando-se como elemento referenciador - esquema proposto por BRONFMAN e TUIRAN ${ }^{11}$, adaptado por LOMBARDI e cols.. ${ }^{42}(1986)$. A utilização da ocupação como 
indicador, tornou possivel identificar os grupos sociais e assim definir sua "situação de classe".

Para BRONFMAN e TUIRAN"11(1984) "A inserção de classe determina, em última instância, o acesso diferencial entre outros à infra-estrutura de saúde, à quantidade e qualidade de alimentos, à habitação e ao vestuário".

LOMBARDI e cols. 42 (1988) consideram que os modelos de operacionalização de classe social possibilitam "captar a situação de classe dos grupos sociais e a forma em que esta afeta a saúde dos indivíduos que a compartem em determinada formação econômico-social". Afirmam, ainda, que "os indicadores tradicionais de estratificação, como renda e escolaridade, mesmo nas tentativas de sua utilização a partir de uma perspectiva dialética, configuram grupos humanos que não compartilham necessariamente a mesma situação de classe, já que implicam cortes arbitrários do pesquisador, que não refletem a complexidade da estrutura social".

No presente estudo, a "situação de classe" das familias foi definida através da inserção dos responsáveis pelo sustento destas nos processos de produção, circulação ou coadjuvantes. Os dados relativos às variáveis utilizadas para compormos esta categoria, encontram-se expressos no ANEXO B.

As familias do estudo foram classificadas como pertencentes a uma das seguintes classes sociais: burguesia, nova pequena burguesia, pequena burguesia tradicional, proletariado não típico, proletariado típico e subproletariado (TABELA 10). A composição das diferentes 
classes sociais, encontra-se especificada no ANEXO C.

A maior proporção da população de estudo integrava familia do proletariado (cerca de 56\%). A seguir, em menores proporçōes, apareciam as familias pertencentes à nova burguesia $(19,7 \%)$ e à pequena burguesia tradicional $(11,2 \%)$. E, finalmente, em situaçōes opostas e em menor proporção, estavam as familias pertencentes ao subproletariado $(9,6 \%$ e à burguesia $(3,4 \%)$.

TABELA 10 - Classe social do responsável pelo sustento da familia.

\begin{tabular}{l|rr}
\hline CLASSES & Freq & \multicolumn{1}{c}{} \\
\hline Subproletariado & 53 & $9.6 \%$ \\
Proletariado Típico & 69 & $12.5 \%$ \\
Proletariado não Típico & 241 & $43.4 \%$ \\
Pequena Burguesia Tradicional & 62 & $11.2 \%$ \\
Nova Pequena Burguesia & 109 & $19.7 \%$ \\
Burguesia & 19 & $3.4 \%$ \\
Sem possibilidade de classificação & 1 & $0.2 \%$ \\
\hline Total & 554 & $100.0 \%$ \\
\hline
\end{tabular}


observamos, através da análise das variáveis sócioeconômico-demográficas, que os atores sociais pesquisados, eram representantes das enormes desigualdades sociais existentes em nosso país.

As diferenças sociais encontravam-se bem demarcadas entre os grupos de mães componentes da nova população de estudo. o grupo mais expressivo, era tomado por mães com baixos niveis de escolaridade e renda, que não trabalhavam e pertencentes às classes populares. Contrapondo-se a este, havia outros grupos, onde os sujeitos de investigação apresentavam melhores níveis de educação, de renda e posições sociais.

Independentemente da inserção social, a população era formada, em grandes proporções, por mulheres jovens, mães de 1 a 2 filhos, casadas, com união estável e que elegiam o marido como o chefe e responsável pelo sustento da família.

\subsection{As criancas pequenas}

Constituindo nosso universo de estudo, representado pelo binômio mãe-filho, temos 554 mães de um total de 693 crianças menores de 5 anos de idade.

Explorando as características demográficas das crianças pequenas, constatamos que houve proporcionalidade no percentual de distribuiçāo destas nas diferentes idades, conforme pode ser visto na tabela 11, com exceção das crianças na faixa etária dos 5 anos de idade, em menor 
proporção na amostra. A idade média das crianças era 2 anos. TABELA 11 - Distribuição dos filhos com até cinco anos segundo a idade.

\begin{tabular}{l|r|c}
\hline ANOS & Freq & $\%$ \\
\hline$<1$ & 114 & $16.5 \%$ \\
1 & 123 & $17.7 \%$ \\
2 & 124 & $17.9 \%$ \\
3 & 137 & $19.8 \%$ \\
4 & 151 & $21.8 \%$ \\
5 & 44 & $6.3 \%$ \\
\hline Total & 693 & $100.0 \%$ \\
\hline
\end{tabular}

Quanto a divisão das crianças pequenas por gênero, descobrimos que aproximadamente $50 \%$ destas pertenciam ao sexo masculino e $50 \%$ ao feminino, sugerindo haver proporcionalidade no nascimento de meninos e meninas (TABELA 12)

TABELA 12 - Distribuição dos filhos menores de cinco anos de idade segundo o sexo.

\begin{tabular}{l|cc}
\hline SEXO & Freq & $\%$ \\
\hline MASCULINO & 351 & $50.6 \%$ \\
FEMININO & 342 & $49.4 \%$ \\
\hline Total & 693 & $100.0 \%$ \\
\hline
\end{tabular}


2. As MĀEs E A SAÚde BUCAL

Com relação ao tema saúde bucal infantil, parecem ainda não explicitadas as complexas relaçōes entre o conhecimento científico, o conhecimento do "senso-comum"e o conhecimento técnico dos profissionais atuantes nos serviçosodontológicos. Da mesma forma que a saúde bucal infantil envolve "relaçōes específicas do binômio mãe-criança entre si e deste com o mundo material, social e cultural que o inscreve, o conhecimento científico e o técnico-profissional apresentam-se, igualmente, como parte desse contexto de relaçōes" (OLIVEIRA $\left.{ }^{60}, 1990\right)$.

Para compreendermos como essas três esferas do saber se articulam e se estreitam, há necessidade de se buscar a forma como cada um desses interlocutores concebem, entendem - escrevendo ou verbalizando - seu próprio conhecimento sobre o objeto.

- presente estudo vai em direção à busca do "conhecimento do senso comum" partilhado pelas mães. Visa a descrição e a compreensão das representações que estas têm sobre o processo saúde-doença bucal, bem como das práticas a ele associadas. Desta forma, pretendemos relacioná-las aos conhecimentos e comportamentos que estas têm diante dos cuidados da saúde bucal das crianças pequenas. 
Vale mencionar, que temos como pressuposto ao conduzirmos a análise das representaçōes das mães sobre a saúde bucal, que há relaçōes de complementariedade e de conflito entre o "conhecimento do senso comum" destas e o "conhecimento técnico-cientrfico" expresso na literatura odontológica. E, que as relaçōes mais conflitantes devem ser encontradas entre as mães pertencentes às classes populares.

Considerando-se que 0 dentista constitui-se no principal agente de difusão do conhecimento científico odontológico, e que as pessoas vão retraduzindo e incorporando este conhecimento através de contatos freqüentes com este profissional, é de se supor que a população marginalizada com relação ao acesso aos cuidados bucais, que no Brasil sabemos ser a maioria, tenham menos possibilidades de apreender o discurso técnico-científico sobre a saúde bucal.

outro aspecto a ser registrado, é que a distância entre o nível educacional do profissional e aquele das pessoas situadas em baixas posições na hierarquia social, dificulta a comunicação entre estes atores sociais, estando presente uma forte discriminação de classe.

Achamos interessante citar as afirmaçōes de BOLTANSKI ${ }^{6}$ (1989) sobre a relação médico-paciente, considerando que estas possam, perfeitamente, serem transportadas para área odontológica, refletindo bem a comunicação entre o dentista e seus pacientes. Segundo ele, "A frequência e a intensidade das relações que os doentes 
mantêm com o médico e a qualidade do "colóquio singular" crescem quando se sobe na hierarquia social, ou seja, quando diminui a distância social entre o médico e seu doente... Membros das classes superiores que, por definição, pertencem à mesma classe social que seu médico, ou ainda, ao mesmo meio... podem declarar que com ele o diálogo é fácil, porque falam a mesma língua, têm os mesmos hábitos mentais, empregam categorias de pensamento semelhantes, enfim, sofreram a influência da mesma força formadora de hábitos que, na ocorrência, é o sistema de educação... No extremo oposto, os membros das classes populares, estão afastados dele pela distância social que em qualquer eventualidade, separa um membro das classes superiores altamente escolarizado e detentor de um saber especifico, de um membro das classes populares e que é aumentada neste caso pela distância Iinguistica, devida, ao mesmo tempo, a diferenças lexicológicas e sintáticas que separam a língua das classes cultas da lingua das classes populares".

No entender do autor, as diferenças de classe e, principalmente, de nível de instrução, limitam bastante a interação entre o profissional e o cliente e, portanto, a difusão do saber técnico-científico do profissional de saúde, nos contatos que este tem com seus pacientes. Além disso, a posse de conhecimentos dá poder ao profissional de saúde, que - detém, não querendo dividílo com o cliente, matendo com ele relaçōes impessoais e verticais. Desta forma, há uma relação bastante desigual, sendo que, à esta situação, o 
paciente costuma responder com passividade e submissão, refreando questōes ou formulando-as de forma inadequada

\subsection{Representaçōes sobre o processo saúde-doença bucal}

As representações da população de estudo acerca do processo saúde-doença bucal foram extraídas, através da abordagem de dois assuntos básicos desenvolvidos na área acadêmica odontológica: a concepção sobre os dentes e a doença cárie dentária.

\section{Concepçōes sobre os dentes e sua importância}

Para captarmos o grau de valorização e conhecimento das mães com relação a importância dos dentes, formulamos questōes simples e objetivas, cujos "tratar de seus corpos" e - "cuidar de seus filhos", cotidianamente, facilmente lhes permitiria responder.

Arguidas sobre o número total de dentes permanentes que o adulto pode possuir, 50\% das entrevistadas disseram que - desconheciam e, igualmente, 50\% afirmaram conhecê-lo. No entanto, quando solicitamos a este último grupo de mães que apontasse $\circ$ número total, apenas $54,7 \%$ destas, responderam corretamente (TABELAS 13 e 14). 


\begin{tabular}{|c|c|c|c|}
\hline \multirow[t]{6}{*}{ TABELA 1} & $\begin{array}{l}\text { - Distribuição } \\
\text { conhecimento } \\
\text { permanentes. }\end{array}$ & \multicolumn{2}{|c|}{$\begin{array}{cc} & \text { mães se } \\
\text { o número }\end{array}$} \\
\hline & CONHECIMENTO & Freq & $\%$ \\
\hline & $\mathrm{NÃO}$ & 277 & $50.0 \%$ \\
\hline & SIM & 276 & $49.8 \%$ \\
\hline & NÃO RESPONDEU & 1 & $0.2 \%$ \\
\hline & Total & 554 & $100.0 \%$ \\
\hline
\end{tabular}

Na verdade, a maioria das mães do estudo $(72,5 \%)$ desconhecia o total de dentes permanentes, que elas próprias deveriam possuir, excetuando-se situaçōes de perdas dentárias. Este fato denota falta de conhecimento e pouca preocupação com os dentes, o que parece ser um traço da sociedade brasileira, de modo geral.

TABELA 14 - Número de dentes permanentes segundo as mães.

\begin{tabular}{l|rr}
\hline INFORMAÇÃO & Freq & $\%$ \\
\hline Número correto & 151 & $54.7 \%$ \\
Número incorreto & 125 & $45.3 \%$ \\
\hline Total & 276 & $100.0 \%$ \\
\hline
\end{tabular}


Fomos em busca das mesmas informaçōes, com relação ao número de dentes deciduos. $76,2 \%$ das mães nāo souberam responder e entre aquelas que responderam, $60,6 \%$ o fizeram incorretamente (TABELAS 15 e 16), o que traduzido em números reais, significa que $90,6 \%$ das mães de nosso estudo, desconheciam o número total de dentes decíduos que seus filhos pequenos já possuiam ou viriam a possuir.

Ponderando-se sobre o fato de que cerca de $66 \%$ das crianças de nosso estudo tinham idades acima de 2 anos, e que por volta de 2 anos e meio de idade a criança já apresenta os 20. dentes decíduos, é de se imaginar que as entrevistadas, simplesmente, não estavam prestando muita atenção para o interior das bocas de seus filhos pequenos, da mesma forma que a sua própria boca, de acordo com o que inferimos das tabelas 13 e 14 .

TABELA 15 - Distribuição das mães segundo o provável conhecimento sobre o número total de dentes decíduos.

\begin{tabular}{l|rc}
\hline CONHECIMENTO & Freq & $\%$ \\
\hline NĀO & 422 & $76.2 \%$ \\
SIM & 132 & $23.8 \%$ \\
\hline Total & 554 & $100.0 \%$ \\
\hline
\end{tabular}


TABELA 16 - Número total de dentes decíduos segundo as mães.

\begin{tabular}{l|rc}
\hline INFORMAÇÃO & Freq & $\%$ \\
\hline Número correto & 52 & $39.4 \%$ \\
Número incorreto & 80 & $60.6 \%$ \\
\hline Total & 132 & $100.0 \%$ \\
\hline
\end{tabular}

Procedemos a análise multivariada procurando buscar relaçōes entre as características sócio-econômicas das māes, - fato de elas já terem procurado o dentista para algum de seus filhos menores e o desconhecimento demonstrado pelas mesmas com relação ao número de dentes decíduos que a criança apresenta (QUADRO 1).

Constatamos que as seguintes características: escolaridade, renda "per capita", classe social e visitas ao dentista apresentaram resultados significantes, quando analisadas na associação com o desconhecimento das mães. 
QUADRO $N^{\circ} 1$ - Total $(n)$, número(n1) e $\%$ de mães que não conheciam o número de dentes deciduos segundo características sócio-econômicas e visita ao dentista.

\begin{tabular}{|c|c|c|c|c|c|c|}
\hline CARACTERISTICAS & $\underset{n}{\text { TOTAL }}$ & $\begin{array}{r}\text { NÃO } \\
\text { n1 }\end{array}$ & $\begin{array}{c}\text { CONHECIAM } \\
\%\end{array}$ & $x^{2}$ & gl & $\mathrm{p}$ \\
\hline $\begin{array}{l}\text { GRUPO ETÁRIO } \\
15-24 \\
25-29 \\
30-34 \\
35-49\end{array}$ & $\begin{array}{r}154 \\
190 \\
137 \\
62\end{array}$ & $\begin{array}{r}122 \\
144 \\
103 \\
47\end{array}$ & $\begin{array}{l}79,2 \\
75,8 \\
75,2 \\
75,8\end{array}$ & 0,84 & 3 & 0,841 \\
\hline $\begin{array}{l}\text { ESCOLARIDADE } \\
\text { Analf / } 1^{\circ} \text { GRAU INC. } \\
1^{\circ} \text { GRAU COMPIETO } \\
2^{\circ} \text { GRAU COMPLETO } \\
3^{\circ} \text { GRAU COMPLETO }\end{array}$ & $\begin{array}{r}256 \\
100 \\
131 \\
54\end{array}$ & $\begin{array}{r}214 \\
74 \\
91 \\
32\end{array}$ & $\begin{array}{l}83,6 \\
74,0 \\
69,5 \\
59,3\end{array}$ & $19,66^{*}$ & 3 & 0,000 \\
\hline $\begin{array}{l}\text { OCUPAÇÃO } \\
\text { Sim } \\
\text { Nao }\end{array}$ & $\begin{array}{l}206 \\
291\end{array}$ & $\begin{array}{l}150 \\
228\end{array}$ & $\begin{array}{l}72,8 \\
78,4\end{array}$ & 1,74 & 1 & 0,188 \\
\hline
\end{tabular}

RENDA PER CAPITA

0,027

\begin{tabular}{|c|c|c|c|c|c|c|}
\hline $\begin{array}{l}\text { Ate } 1 \text { sal.Min. } \\
>1 \text { a } 3 \text { sal.Min. } \\
>3 \text { a } 10 \text { sal.Min. }\end{array}$ & $\begin{array}{r}231 \\
207 \\
60\end{array}$ & $\begin{array}{r}192 \\
144 \\
42\end{array}$ & $\begin{array}{l}83,1 \\
69,6 \\
70,0\end{array}$ & & & \\
\hline $\begin{array}{l}\text { CLASSE SOCIAL } \\
\text { Burguesia } \\
\text { Proletariado } \\
\text { Subproletariado }\end{array}$ & $\begin{array}{r}189 \\
309 \\
52\end{array}$ & $\begin{array}{r}129 \\
253 \\
38\end{array}$ & $\begin{array}{l}68,3 \\
81,9 \\
73,1\end{array}$ & $12,4^{\star}$ & 2 & 0,002 \\
\hline $\begin{array}{l}\text { No.FILHOS }<5 \text { ANOS } \\
1 \\
2-3\end{array}$ & $\begin{array}{l}421 \\
130\end{array}$ & $\begin{array}{r}324 \\
97\end{array}$ & $\begin{array}{l}77,0 \\
74,6\end{array}$ & 0,19 & 1 & 0,666 \\
\hline $\begin{array}{l}\text { VISITA AO DENTISTA } \\
\text { SIM } \\
\text { NAO }\end{array}$ & $\begin{array}{l}203 \\
321\end{array}$ & $\begin{array}{l}136 \\
264\end{array}$ & $\begin{array}{l}67,0 \\
82,2\end{array}$ & $15,17^{*}$ & 1 & 0,000 \\
\hline TOTAL & 551 & 421 & 76,4 & & & \\
\hline
\end{tabular}

REGRESSÃO LOGÍSTICA - RESULTADOS ANÁLISE DE VARIÂNCIA

\begin{tabular}{lrrr}
\hline Fonte de Variação & GL & Qui-Quad. & Prob. \\
\hline INTERCEPT & 1 & 26.41 & $0.0000 *$ \\
RENDAPER & 2 & 4.53 & 0.1040 \\
VISITA AO DENTISTA & 1 & 12.30 & $0.0005 *$ \\
ESCOLRIDADE & 3 & 6.11 & 0.1062 \\
CLASSE SOCIAL & 2 & 3.72 & 0.1555 \\
RAZÃO DE MAXIMO- & 46 & 52.73 & 0.2299 \\
VEROSSIMILHANÇA & & &
\end{tabular}

(*) Significante ao nível de $5 \%$. 


\section{observamos que o desconhecimento manifestado pelas}

mães, sobre o número de dentes, foi inversamente proporcional ao nivel de escolaridade e de renda destas, ou seja, maiores proporções de mães, mais pobres e com menos anos de estudo, desconheciam o total dos dentes decíduos.

com relação à classe social, encontramos um dado interessante, maiores porcentagens de mães situadas no proletariado $(81,9 \%)$ em relação àquelas pertencentes ao subproletariado $(73,1 \%)$ desconheciam este valor.

As diferenças mais importantes nas proporçōes de mães que desconheciam o número de dentes decíduos foram encontradas na associação desta variável de estudo com a variável visita de algum dos filhos menores ao dentista. Sendo que, na situação onde a visita ao dentista havia ocorrido, menor percentual das mães (67\%) manifestou desconhecimento, ao passo que, quando esta não havia acontecido, $82,2 \%$ das mães não sabiam dizer o número de dentes decíduos.

Estes dados estão concordantes com a análise de regressão logística, que permitiu-nos considerar como único fator relacionado ao desconhecimento das mães, sobre o número total de dentes deciduos, apenas, a visita ao dentista.

Desta forma, podemos dizer que, independentemente do nível de instrução, da renda familiar e da posição de classe, quase que a totalidade das mães de nosso estudo não sabia o número de dentes decíduos que a criança apresenta. 
- contato da mãe com o dentista, foi a única variável associada ao conhecimento sobre o número de dentes, - que indica ser, o acesso ao atendimento odontológico muito importante, para uma maior valorização da saúde bucal.

Ainda dentro deste assunto, avaliamos se as mães de nosso estudo, conheciam as funçōes dos dentes decíduos. A elas foi perguntado sobre a utilidade destes.

As respostas obtidas estão expressas, na TABELA 17, onde observa-se que, um pouco mais da metade das mães disseram não conhecer as funções destes dentes.

$\begin{aligned} \text { TABELA } 17- & \begin{array}{l}\text { Distribuição das mães segundo o provável } \\ \text { conhecimento sobre as funços dos dentes } \\ \text { decíduos. }\end{array}\end{aligned}$

\begin{tabular}{l|rc}
\hline CONHECIMENTO & Freq & $\%$ \\
\hline NÃO & 304 & $54.8 \%$ \\
SIM & 248 & $44.8 \%$ \\
NÃO RESPONDEU & 2 & $0.4 \%$ \\
\hline TOTAL & 554 & $100.0 \%$ \\
\hline
\end{tabular}

Entre as funções apontadas pelas mães, a que teve maior reconhecimento por parte destas, foi a mastigação $(53,2 \%)$, provavelmente, por haver entre elas, maior preocupação com aspectos relacionados à alimentação, ao crescimento e desenvolvimento das crianças. Pequenos percentuais fizeram a associação entre a mastigação e outras funções, como a estética e a fonação. E $27 \%$ das mães 
relataram, que de alguma forma, os dentes decíduos eram importantes para a instalação da dentição sucessora - a permanente, porém, não souberam explicar o modo como se daria. (TABELA 18)

TABELA 18 - Funçōes dos dentes deciduos segundo as mães.

\begin{tabular}{l|rr}
\hline FUNÇōES & Freq & \multicolumn{1}{c}{$\%$} \\
\hline Mastigação & 132 & $53.2 \%$ \\
Mastigação e estética & 13 & $5.3 \%$ \\
Mastigação/fonação/estética & 10 & $4.0 \%$ \\
Instalação dentição permanente & 67 & $27.0 \%$ \\
Outras & 26 & $10.5 \%$ \\
\hline TOTAL & 248 & $100.0 \%$ \\
\hline
\end{tabular}

Como esta foi uma questão aberta, através das "falas" das mães, pudemos perceber que estas não se constituíam em reproduções do conhecimento científico, e sim este saber era oriundo das percepçōes das mães ao cuidar cotidianamente das crianças pequenas. Achamos interessante, colocar aqui algumas falas das mães a este respeito, com o intuito de chamar atenção para a existência de várias representações à cerca do mesmo objeto. 
Segundo elas, os dentes decíduos servem ou são úteis para:

" a criança sè acostumar com os verdadeiros..." "para cairem e os outros nascerem..." "para serem estragados..." "porque no começo as crianças estragam mais facilmente os dentes".

São falas que fazem transparecer a situação de transitoriedade da dentição decídua, e a pouca valorização dada a estes dentes, que no entender das mães não são os "verdadeiros" e logo "vão cair". Expressam, também, o conformismo destas com as situaçōes precárias da saúde bucal infantil, pois, segundo elas, este tipo de dente serve para ser "estragado", portanto, é natural estar cariado.

Na visão de outras mães, servem para:

"enfeitar..." "a criança não ficar feia..." "a criança não ficar banguela".

Estas representações demonstram a preocupação por parte de algumas mães apenas com o aparente, não havendo a percepção por parte destas dos processos fisiológicos associados a existência dos dentes decíduos. 


\section{A Doença cárie dentária}

No meio acadêmico odontológico a cárie é tida como uma doença infecto contagiosa, que resulta em uma perda localizada de miligramas de minerais dos dentes afetados, causada por ácidos orgânicos provenientes da fermentação microbiana dos carboidratos da dieta, tem caráter multifatorial e é, usualmente, crônica91.

As explicaçōes sobre a ocorrência da cárie são embasadas em um modelo ecológico simplificado, que vem sendo, universalmente, aceito durante as últimas três décadas. É conhecido como a tríade de $\operatorname{KEYES}^{79}$, segundo o qual a cárie dentária é resultante da interação de três fatores essenciais, quais sejam, o hospedeiro, representado pelos dentes e a saliva; o agente agressor, no caso, a microbiota da região; e o meio ambiente, expresso pelo substrato ou dieta consumida. Para que a doença se desenvolva deve haver condições favoráveis a cada um destes fatores, ou seja, o hospedeiro deve ser susceptível, a microbiota bucal cariogênica e o substrato adequado ${ }^{56}$.

A teoria da multicausalidade, representou para a área da saúde, um resgate do social, ainda que, de forma parcial ou desfigurada, pois conforme relata BURALLI ${ }^{12}(1986)$, "esta teoria, buscando ampliar seu nível de explicação, circunscrito à relação agente-hospedeiro, incorpora um terceiro elemento de análise - o meio ambiente - o qual passa a constituir, com os dois elementos anteriores, a chamada 
triade ecológoca. O meio ambiente, entendido como englobando todos os fatores físicos, químicos e sociais, possibilitou o avanço de uma visão social do processo saúde-doença".

No caso especifico do modelo explicativo da cárie dentária, percebe-se que a dimensão social foi relegada ao ostracismo, ficando o meio ambiente que a ela se relaciona, restrito aos efeitos biológicos de substratos cariogênicos ou, quando muito, a comportamentos alimentares considerados inapropriados.

Este modelo pode resultar na falsa noção de, "falta de saúde", como resultado de escolha pessoal, considerando o homem como o próprio responsável pela sua doença ao escolher viver de forma não saúdavel ${ }^{12}$. Além disso, desconsidera os processos sociais, entre eles a saúde-doença, como expressōes de certos modos de produção das classes sociais em que estes dividem a sociedade, procurando entender as razóes pelas quais, cada classe social está exposta a diferentes riscos de adoecer e possibilidades de manter a saúde.

A prevenção da cárie, baseada neste modelo explicativo, tem sido feita através de medidas que visam aumentar a resistência do hospedeiro (terapia com flúor e selantes oclusais); diminuir o número de microorganismos que estão em contato com o dente (controle químico e mecânico de placa); modificar o substrato através da seleção de gêneros alimentícios não cariogênicos; e, reduzir a permanência do substrato na boca, limitando a freqüência de ingestão. Assim, o controle desta doença, pela própria característica inerente 
à sua forma de análise é apresentado em termos técnicos. Nesta medida, problemas de ordem politico-social são resolvidos de um ponto de vista extritamente técnico.

Após esta rápida abordagem sobre o conceito, as causas e formas de prevenção da cárie, do ponto de vista acadêmico, passamos a apresentar as representações das mães a cerca do mesmo objeto.

Primeiramente, procuramos saber se as entrevistadas incluiam a cárie dentária, entre as doenças da boca, mais comuns. Perguntou-se então, se elas conheciam quais eram estas doenças. Cerca de $66 \%$, afirmaram poder identificar as doenças da boca, mais comuns. (TABELA 19). As mais citadas foram a cárie e a gengivite, como pode ser visto na tabela 20. Um número expressivo de mães (cerca de $29 \%$ ) apontou a afta, seguindo-se o mau hálito.

A título de esclarecimento, na população infantil, as condições ou doenças mais comuns que podem conduzir à disfunção bucal são a cárie dentária, maloclusões, defeitos adquiridos tais como aqueles devidos a traumas ou injúrias, lesões do tecido mole e pré-cancerosas, doenças periodontais e anomalias congênitas. (RAYMER e GIFT ${ }^{66}$, 1990) 
TABELA 19 - Distribuição das mães segundo o conhecimento sobre as doenças da boca mais comuns.

\begin{tabular}{l|rc}
\hline CONHECIMENTO & Freq & $\%$ \\
\hline NĀO & 188 & $34.1 \%$ \\
SIM & 365 & $65.9 \%$ \\
NĀO RESPONDEU & 1 & $0.2 \%$ \\
\hline Total & 554 & $100.0 \%$ \\
\hline
\end{tabular}

TABELA 20 - Tipos de doenças da boca mais comuns segundo as mães.

\begin{tabular}{l|rr}
\hline DOENÇA & Freq \\
\hline Cárie & 118 & $32.3 \%$ \\
Gengivite & 63 & $17.3 \%$ \\
Cárie/Problema periodontal & 30 & $8.2 \%$ \\
Mau hálito & 14 & $3.8 \%$ \\
Afta & 105 & $28.8 \%$ \\
Outros & 35 & $9.6 \%$ \\
\hline Total & 365 & $100.0 \%$ \\
\hline
\end{tabular}

Daquelas mães que afirmaram conhecer as doenças, $40 \%$ se referiam a cárie dentária. Considerados um percentual reduzido, pois a maioria das pessoas, em nosso país, tem experiência com esta doença no decorrer das suas vidas. 
Temos, também, que levar em consideração o percentual significativo de mães ( $34 \%$ ) que não souberam dizer quais são as doenças bucais mais comuns e, também, o alto percentual $(42,2 \%)$ de outros tipos de doenças identificadas pelas mães, como "aftas, mau hálito, herpes, câncer, "boqueira", "sapinho", "bolhas que dão nos dentes".

Atestando o acesso desigual da população aos serviços odontológicos e o monopólio do conhecimento cientifico por grande parte do segmento profissional, refletindo no precário desempenho deste no desenvolvimento de açōes educativas, $61,4 \%$ das mães deste estudo, afirmaram nunca ter recebido qualquer explicação sobre a cárie dentária (TABELA 21).

TABELA 21 - Distribuição das mães segundo o contato prévio com explicaçōes sobre cárie dentária.

\begin{tabular}{l|rc}
\hline Contato com Explicaçōes & Freq & $\%$ \\
\hline NÃO & 340 & $61.4 \%$ \\
SIM & 214 & $38.6 \%$ \\
\hline Total & 554 & $100.0 \%$ \\
\hline
\end{tabular}

Através de análise multivariada procuramos estabelecer relaçōes entre este fato, características sócioeconômicas das entrevistadas e a provável procura destas pelo dentista para um dos seus filhos pequenos. 
- QUADRO 2 deixa transparecer que as variáveis grupo-etário, escolaridade, ocupação, renda "per capita", classe social e visita ao dentista, apresentaram resultados significantes na análise de associação com a falta de contato prévio das mães com explicações sobre a cárie. Contudo, após a análise de regressão logística, houve permanência de associação da variável de estudo, apenas com as caracteristicas: escolaridade, ocupação, classe social e visita ao dentista.

Tornando mais explicitos estes resultados, podemos dizer que as maiores proporções de mães, que não haviam recebido explicaçōes sobre esta doença, possuiam os menores níveis de escolaridade $(76,6 \%)$ e pertenciam a classe proletária $(72,5 \%)$ ou ao subproletariado $\quad((75 \%)$. Em contrapartida, as menores proporçōes destas, apresentavam o $3^{\circ}$ grau completo $(22,2 \%)$ e faziam parte da burguesia $(39,7 \%)$. Estes dados confirmam as desigualdades sociais, anteriormente referidas, no acesso às informações odontológicas.

As māes que possuiam ocupação remunerada, em menor proporção $(51,9 \%)$ em relação àquelas que não trabalhavam $(67,7 \%)$, afirmaram não terem sido orientadas sobre a doença. Apesar de, a maior porcentagem de mães $(69,2 \%)$ que não havia recebido orientaçōes, ter afirmado que não havia ainda procurado o dentista para seus filhos menores, deparamo-nos com 50,2\% destas, que já o haviam visitado, sem contudo terem sido orientadas. 
Do total das māes entrevistadas, 38,6\% afirmaram terem tido contato prévio com explicaçōes sobre a doença. E, como podemos deduzir pela análise anterior, estas, provavelmente, possuiam melhores condições de vida, expressas em niveis mais altos de escolaridade e melhores posições sociais, o que também, poderia lhes conferir acesso diferenciado aos serviços e às informações odontológicas. 
QUADRO $\mathrm{N}^{\circ} 2$ - Total(n), número(n1) e \% de mães segundo contato prévio com explicações sobre cárie dentária, características sócio-econômicas e visita ao dentista.

\begin{tabular}{|c|c|c|c|c|c|}
\hline CARACTERISTICAS & $\begin{array}{l}\text { TOTAL } \\
\mathrm{n}\end{array}$ & $\begin{array}{r}\mathrm{NA} O \\
\mathrm{n} 1\end{array}$ & $\%$ & $x^{2}$ & $p$ \\
\hline $\begin{array}{l}\text { GRUPO ETÁRIO } \\
15-24 \\
25-29 \\
30-34 \\
35-49\end{array}$ & $\begin{array}{r}154 \\
190 \\
137 \\
62\end{array}$ & $\begin{array}{r}109 \\
114 \\
73 \\
38\end{array}$ & $\begin{array}{l}70,8 \\
60,0 \\
53,3 \\
61,3\end{array}$ & $9,69 * 3$ & 0,021 \\
\hline $\begin{array}{l}\text { ESCOLARIDADE } \\
\text { Anal.f/IO GRAU INC. } \\
1^{\circ} \text { GRAU COMPLETO } \\
2^{\circ} \text { GRAU COMPLETO } \\
3^{\circ} \text { GRAU COMPLETO }\end{array}$ & $\begin{array}{r}256 \\
100 \\
131 \\
54\end{array}$ & $\begin{array}{r}196 \\
61 \\
60 \\
12\end{array}$ & $\begin{array}{l}76,6 \\
61,0 \\
45,8 \\
22,2\end{array}$ & $72,78 * 3$ & 30,000 \\
\hline $\begin{array}{l}\text { OCUPAÇÃO } \\
\text { Sim } \\
\text { NaO }\end{array}$ & $\begin{array}{l}206 \\
291\end{array}$ & $\begin{array}{l}107 \\
197\end{array}$ & $\begin{array}{l}51 ; 9 \\
67,7\end{array}$ & $11,95 * 1$ & 10,000 \\
\hline $\begin{array}{l}\text { RENDA PER CAPITA } \\
\text { Ate } 1 \text { sal.Min. } \\
>1 \text { a } 3 \text { Sal.Min. } \\
>3 \text { a } 10 \text { Sal.Min. }\end{array}$ & $\begin{array}{r}231 \\
206 \\
60\end{array}$ & $\begin{array}{r}161 \\
116 \\
21\end{array}$ & $\begin{array}{l}69,7 \\
56,0 \\
35,0\end{array}$ & $25,99^{*}$ & 20,000 \\
\hline $\begin{array}{l}\text { CLASSE SOCIAL } \\
\text { Burguesia } \\
\text { Proletariado } \\
\text { Subproletariado }\end{array}$ & $\begin{array}{r}189 \\
309 \\
52\end{array}$ & $\begin{array}{r}75 \\
224 \\
39\end{array}$ & $\begin{array}{l}39,7 \\
72,5 \\
75,0\end{array}$ & $57,74^{*}$ & 20,000 \\
\hline $\begin{array}{l}\text { NO. FILHOS }<5 \text { ANOS } \\
1 \\
2-3\end{array}$ & $\begin{array}{l}421 \\
130\end{array}$ & $\begin{array}{r}253 \\
85\end{array}$ & $\begin{array}{l}60,1 \\
65,4\end{array}$ & 0,96 & 10,327 \\
\hline $\begin{array}{l}\text { VISITA AO DENTISTA } \\
\text { SIM } \\
\text { NÃO }\end{array}$ & $\begin{array}{l}203 \\
321\end{array}$ & $\begin{array}{l}102 \\
222\end{array}$ & $\begin{array}{l}50,2 \\
69,2\end{array}$ & $0,04^{*}$ & 10,836 \\
\hline TOTAL & 554 & 340 & 61,4 & & \\
\hline
\end{tabular}

REGRESSĀO LOGÍSTICA - RESULTADOS ANÁLISE DE VARIÂNCIA

\begin{tabular}{|c|c|c|c|}
\hline Fonte de Variação & GL & Qui-Quad. & Prob. \\
\hline INTERCECÇÃO & 1 & 0.55 & .4599 \\
\hline ESCOLARIDADE & 3 & 20.39 & $0.0001 *$ \\
\hline OCUPAÇÄO & 1 & 5.36 & $207 *$ \\
\hline CLASSE SOCIAL & 2 & 11.20 & $0.0037 \star$ \\
\hline VISITA DENTISTA & 1 & 13.52 & $0.0002 *$ \\
\hline RAZÃO MAXIMO- & 34 & 41.70 & 0.1708 \\
\hline VEROSSIMILHANÇA & & & \\
\hline
\end{tabular}

(*) - Significante ao nível de $5 \%$. 
Entre as fontes de explicaçōes mencionadas por este grupo de mães, em primeiro lugar temos o dentista particular (35\%), seguido da escola $(24,8 \%)$ e dentista de serviço público $(17,3 \%)$, (TABELA 22).

Percebemos, portanto, que entre a pequena parcela de mães que afirmaram ter recebido explicações sobre a cárie, dentistas, tanto de serviços privados, como públicos, constituiram-se em importantes fontes de orientação, confirmando, novamente, 0 importante papel destes profissionais na difusão do conhecimento cientifico odontológico.

No nosso entender, a escola aqui referida pelas mães, deve estar relacionada às atividades educativas que fazem parte do programa de atenção odontológica aos escolares, desenvolvido pelas secretarias municipal e estadual de saúde. 
TABELA 22 - Fonte de explicação sobre cárie dentária às mães.

\begin{tabular}{l|rc}
\hline FONTE & Freq & \multicolumn{1}{c}{$\%$} \\
\hline Mãe da entrevistada & 2 & $0.9 \%$ \\
Dentista particular & 75 & $35.0 \%$ \\
Dentista - serviço público & 37 & $17.3 \%$ \\
Televisão & 13 & $6.1 \%$ \\
Escola & 53 & $24.8 \%$ \\
Leituras diversas & 11 & $5.1 \%$ \\
Outros & 23 & $10.7 \%$ \\
\hline Total & 214 & $100.0 \%$ \\
\hline
\end{tabular}

Tendo como pressuposto, que as mães, independentemente, da explicação científica sobre a cárie dentária constroem seu próprio conceito sobre esta doença, tentamos identifica-10. Confrontamo-nos com o fato de que cerca de $39 \%$ das mães de nosso estudo, não terem conseguido expressar qualquer conceito, $O$ que pode ser um sinal da dificuldade de relacionamento, de insegurança na relação com profissionais de outra classe, considerados como detentores do saber técnico-científico. 
TABELA 23 - Distribuição das mães segundo a capacidade de conceituação sobre cárie dentária.

\begin{tabular}{l|rc}
\hline CONCEITUAÇĀO & Freq & $\%$ \\
\hline NĀO & 215 & $38.8 \%$ \\
SIM & 338 & $61.0 \%$ \\
NÃO RESPONDEU & 1 & $0.2 \%$ \\
\hline Total & 554 & 100.0 \\
\hline
\end{tabular}

Uma parcela significativa das mães $(23,1 \%)$, associou a doença cárie a seus sinais, traduzidos por "furo... buraco... rombo... destruição... dentes estragados", ou "dentes pretos... amarelos... escurecidos". outra parcela $(24,3 \%)$, promoveu a associação entre a doença e - que consideravam como a provável causa da mesma, reportando-se a comportamentos negativos de saúde, como "cárie é falta de cuidado... falta de higiene... sujeira nos dentes... restos de alimentos nos dentes".

Houve um grupo de mães $18,3 \%$ que se referiu à: "presença de bactérias... microorganismos... placa bacteriana", sem contudo explicitar o papel destes agentes no processo da doença. Provavelmente, estas mães captaram fragmentos das informáçōes científicas, sem contudo apreendê-las ou entendê-las. 
outro grupo de mães $(27,5 \%)$ reproduziu a fala dos profissionais, usualmente, utilizada por estes, ao se comunicarem com crianças pequenas: "cárie é o bichinho que come os dentes" (TABELA 24).

TABELA 24 - Conceito da cárie dentária segundo as mães.

\begin{tabular}{l|rc}
\hline CONCEITO & Freq & $\%$ \\
\hline Furo/buraco & 21 & $6.2 \%$ \\
Cor amarela/escura & 25 & $7.4 \%$ \\
Destruição & 32 & $9.5 \%$ \\
Falta cuidado/higiene & 82 & $24.3 \%$ \\
"Bichinho que come os dentes" & 93 & $27.5 \%$ \\
Placa bacteriana & 62 & $18.3 \%$ \\
Outros & 23 & $6.8 \%$ \\
\hline Total & 338 & $100.0 \%$ \\
\hline
\end{tabular}

Percebemos que, no geral, as mães de nosso estudo não tinham uma idéia clara sobre o que é a cárie dentária.

Procedeu-se a análise multivariada na busca da associação entre as características sócio-econômicas das mães, a visita destas ao dentista e a capacidade apresentada por estas de conceituar a doença (QUADRO 3 ).

As características que apresentaram resultados significantes, na análise de associaçāo com a variável de estudo foram: grupo etário, escolaridade, ocupação, renda "per capita", classe social e número de filhos menores de 5 
anos. Porém, a análise de regressão logística, permitiu-nos considerar como fatores relacionados à capacidade de conceituaçāo, apenas, a escolaridade, classe social e números de filhos menores de 5 anos.

Assim, entre as mães que possuiam $\circ 3^{\circ}$ grau completo e que pertenciam a burguesia, registraram-se as maiores proporçōes daquelas $(88,9$ e $77,2 \%)$ com capacidade de conceituar a doença $e$, entre as mães que apresentavam apenas um filho menor de 5 anos, também, houve maior proporção $(64,5 \%)$ daquelas com capacidade de conceituação.

Em concordância com esta observação, KINNBY e cols. 36 (1991), ao desenvolverem um estudo com o objetivo de interpretar a maneira pela qual informações sobre cuidados com saúde bucal foram assimiladas entre pais de pré-escolares com diferentes experiências de cárie, também, encontraram que - maior conhecimento sobre a cárie dentária estava diretamente associado aos niveis mais altos de escolaridade apresentados pelos pais. Para os autores, os pais de nivel educacional mais elevado, demonstraram maior interesse em assimilar novas informações e em criar uma comunicação "a dois" com o informante. 
QUADRO $\mathrm{N}^{\circ} 3$ - Total $(n)$, número(n1) e \% de mães segundo capacidade conceituar cárie, características sócio-econômicas e visita ao dentista

\begin{tabular}{|c|c|c|c|c|c|c|c|}
\hline CARACTERISTICAS & $\underset{n}{\text { TOTAL }}$ & $\mathrm{n} 1^{\mathrm{SI}}$ & $\%$ & $x^{2}$ & gl & $p$ & \\
\hline $\begin{array}{l}\text { GRUPO ETÁRIO } \\
15-24 \\
25-29 \\
30-34 \\
35-49\end{array}$ & $\begin{array}{r}154 \\
190 \\
136 \\
62\end{array}$ & $\begin{array}{r}83 \\
112 \\
89 \\
47\end{array}$ & $\begin{array}{l}53,9 \\
58,9 \\
65,4 \\
75,8\end{array}$ & & $10,45^{*}$ & 3 & 0,015 \\
\hline $\begin{array}{l}\text { ESCOLARIDADE } \\
\text { Analf/1 }{ }^{\circ} \text { GRAU INC. } \\
1^{\circ} \text { GRAU COMPLETO } \\
2^{\circ} \text { GRAU COMPLETO } \\
3^{\circ} \text { GRAU COMPLETO }\end{array}$ & $\begin{array}{r}256 \\
99 \\
131 \\
54\end{array}$ & $\begin{array}{r}135 \\
59 \\
90 \\
48\end{array}$ & $\begin{array}{l}52,7 \\
59,6 \\
68,7 \\
88,9\end{array}$ & & $28,43^{*}$ & 3 & 0,000 \\
\hline $\begin{array}{l}\text { OCUPAÇĀo } \\
\text { Sim } \\
\text { Nao }\end{array}$ & $\begin{array}{l}206 \\
290\end{array}$ & $\begin{array}{l}144 \\
162\end{array}$ & $\begin{array}{l}69,9 \\
55,9\end{array}$ & & $9,46^{*}$ & 1 & 0,002 \\
\hline $\begin{array}{l}\text { RENDA PER CAPITA } \\
\text { Ate } 1 \text { sal.Min. } \\
>1 \text { a } 3 \text { sal.Min. } \\
>3 \text { a } 10 \text { sal.Min. }\end{array}$ & $\begin{array}{r}230 \\
207 \\
60\end{array}$ & $\begin{array}{r}118 \\
140 \\
49\end{array}$ & $\begin{array}{l}51,3 \\
67,6 \\
81,7\end{array}$ & & $23,74^{*}$ & 2 & 0,000 \\
\hline $\begin{array}{l}\text { CLASSE SOCIAL } \\
\text { Burguesia } \\
\text { Proletariado } \\
\text { Subproletariado }\end{array}$ & $\begin{array}{r}189 \\
308 \\
52\end{array}$ & $\begin{array}{r}146 \\
162 \\
26\end{array}$ & $\begin{array}{l}77,2 \\
52,6 \\
50,0\end{array}$ & & $32,71^{*}$ & 2 & 0,000 \\
\hline $\begin{array}{l}\text { No. FILHOS }<5 \text { ANOS } \\
1 \\
2-3\end{array}$ & $\begin{array}{l}420 \\
130\end{array}$ & $\begin{array}{r}271 \\
64\end{array}$ & $\begin{array}{l}64,5 \\
49,2\end{array}$ & & $9,12^{*}$ & 1 & 0,003 \\
\hline $\begin{array}{l}\text { VISITA AO DENTISTA } \\
\text { SIM } \\
\text { NÃO }\end{array}$ & $\begin{array}{l}203 \\
320\end{array}$ & $\begin{array}{l}128 \\
192\end{array}$ & $\begin{array}{l}63,1 \\
60,0\end{array}$ & & 0,37 & 1 & 0,544 \\
\hline TOTAL & 550 & 335 & 60,9 & & & & \\
\hline
\end{tabular}

REGRESSĀO LOGISTICA - RESULTADOS ANÁLISE DE VARIÂNCIA

\begin{tabular}{lcrc}
\hline Fonte de Variação & GL & Qui-Quad. & Prob. \\
\hline INTERCECÇÃO & 1 & 21.44 & $0.0000 *$ \\
GRUPO ETARIO & 3 & 6.99 & 0.0722 \\
ESCOLARIDADE & 3 & 15.68 & $0.0013^{*}$ \\
OCUPAÇÃO & 1 & 3.37 & 0.0664 \\
CLASSE SOCIAL & 2 & 9.37 & $0.0093^{*}$ \\
NO.FILHOS S5ANOS & 1 & 10.11 & $0.0015 *$ \\
RAZÃO DE MAXIMO- & 105 & 117.05 & 0.1985 \\
VEROSSIMILHANÇA & & & \\
\hline
\end{tabular}

(*) - Significante ao nivel de $5 \%$ 
Após buscarmos as representaçōes das mães sobre o que é a cárie dentária, procuramos verificar as causas da doença apontadas por estas. (TABELA 25).

As mães em sua maioria, 43,6\% indicaram a falta de higiene como causadora da cárie, 20,6\% destas acusaram os doces, 14,1\% citaram ambos fatores como responsáveis.

Novamente, percebemos como as informações são captadas de maneira fragmentada, pois a maioria dos atores investigados relatou apenas um dos fatores implicados no desencadeamento da doença. Além disso nota-se que na ótica da maioria das māes, a cárie tem causas apenas comportamentais.

TABELA 25 - Causa da cárie dentária segundo as mães.

\begin{tabular}{l|rc}
\hline CAUSA & Freq & $\%$ \\
\hline DOCES & 114 & $20.6 \%$ \\
FALTA DE HIGIENE & 236 & $42.6 \%$ \\
DOCES/FALTA HIGIENE & 78 & $14.1 \%$ \\
BACTÉRIA & 10 & $1.8 \%$ \\
FALTA DE CUIDADO & 36 & $6.5 \%$ \\
OUTROS & 30 & $5.4 \%$ \\
NÃO SABE & 50 & $9.0 \%$ \\
\hline TOtaI & 554 & $100.0 \%$ \\
\hline
\end{tabular}


Com relação a possibilidade de prevenção da doença cárie, cerca de $92 \%$ das mães consideram-na viável. A associação dos métodos preventivos, flúor, higiene, dieta, visita ao dentista e educação foi citada por $25,3 \%$ das mães, vindo a seguir, a indicação de medidas isoladas, como a recomendação de visitas ao dentista $(24,2 \%)$, higiene $(22 \%)$ e associação entre higiene e limitação do consumo de doces $(15,1 \%)$. Somente, $2,4 \%$ das entrevistadas referiu-se ao uso do flúor como medida isolada (TABELA 26).

$\hat{E}$ interessante ressaltarmos que, $24,2 \%$ das mães colocaram como única possibilidade de prevenção da cárie, a procura pelo dentista, parecendo-nos que queriam transferir a este profissional toda a responsabilidade pela saúde bucal, não assumindo elas próprias comportamentos preventivos, ou talvez, sequer tivessem consciência de que elas próprias pudessem fazer algo.

Apesar de, a maioria delas $(63,7 \%)$ terem-se reportado a medidas isoladas ou no máximo citado duas $(15,1 \%)$, verificamos que, apenas $25,3 \%$ das mães entrevistadas têm consciência da necessidade de associação de medidas preventivas, para promoção da saúde bucal.

Tanto ao apontarem as causas, como os cuidados preventivos com relação à cárie, foi reduzida a parcela de mães que fizeram associação entre esta e aspectos alimentares. 
TABELA 26 - Métodos preventivos da doença cárie dentária segundo as mäes.

\begin{tabular}{l|rr}
\hline MÉTóo & \multicolumn{2}{|c}{ Freq } \\
\hline Visitas ao dentista & 123 & $24.2 \%$ \\
Higiene & 112 & $22.0 \%$ \\
Higiene/evitar doces & 77 & $15.1 \%$ \\
Alimentação equilibrada & 9 & $1.8 \%$ \\
Uso de flúor & 12 & $2.4 \%$ \\
Flúor/higiene/dieta/visita dentista/educação & 129 & $25.3 \%$ \\
Outros & 47 & $9.2 \%$ \\
\hline Total & 509 & $100.0 \%$ \\
\hline
\end{tabular}

Nas representaçōes das mães sobre a gravidade da doença, identificamos que para um número expressivo destas, a cárie é tida: "como algo normal, pois todo mundo tem... não traz grandes problemas, pois pode ser tratada... é fácil de curar... é só ir ao dentista... pode ser evitada... basta ter cuidados". Seguindo esta linha de pensamento para um menor percentual destas, a cárie "não tem perigo... os dentes não são tão importantes".

Em contrapartida, encontramos, também, um pequeno segmento de mães que reportou encontrar dificuldades para a solução do problema cárie dentária. A principal dificuldade, por elas colocada foi o problema do acesso: "o atendimento dentário é pouco... difícil de ser conseguido... pouco 
atendimento nos postinhos", outras colocaram a questão da recidiva e continuidade do problema: "mesmo com obturação a cárie volta... a cura é quase impossível... com a cárie começam os problemas nos dentes, a gente tenta evitá-la, porém sempre temos... escovar só não adianta, flúor não resolve, o dente acaba estragando do mesmo jeito". E, também, houve referências ao medo do dentista: "o tratamento é dolorido".

Percebemos que existia, entre algumas mães, a crença de que a cárie é o tipo de doença, que uma vez iniciada, traz problemas contínuos para as pessoas. Este pensamento deve ter surgigo diante da inoperância de certos serviços odontológicos e de tratamentos inadequados a que foram submetidas. Segundo THYLSTRUP e FEJERSKOV ${ }^{79}$ (1988), até - início da nova era das investigaçōes sobre a placa dental, durante os anos 60 , os próprios profissionais acreditavam, erroneamente, que uma vez iniciada, a lesão cariosa continuaria a aumentar inexoravelmente.

\subsection{Práticas em relação à saúde bucal}

Hábitos Alimentares

A literatura cientifica odontológica é unânime em considerar que um dos principais fatores biológicos/comportamentais, responsáveis pela instalação do processo carioso nos individuos, está associado a hábitos 
alimentares inadequados. o uso generalizado de açúcares na dieta, sem dúvida alguma, um destes hábitos, constitui-se em um fator extremamente importante na etiologia da cárie dentária.

RUGG-GUNN $^{70}$ (1991) realizou uma extensa revisão sobre a relação entre dieta e cárie dentária, da qual extraiu informações atualizadas e importantes. Sobre os ítens da dieta, geralmente, associados à cárie, o açúcar e o amido, forneceu-nos as seguintes consideraçōes: "A relação entre os açúcares da dieta e a cárie dentária envolve quatro variáveis: quantidade ingerida, frequência de ingestão, concentração no alimento e o tipo de açucar consumido. A quantidade, frequência e concentração de açucar estão ligadas entre si e há evidências de que cada uma destas variáveis é, individualmente, importante no desenvolvimento da cárie.

os principais açúcares da dieta são: sacarose, glicose, maltose, frutose e lactose. A sacarose tem sido considerada como o mais cariogênico, principalmente, por ser - açúcar predominante na dieta. Contudo, a cariogenicidade da glicose, maltose e frutose é semelhante à da sacarose. Um número considerável de evidências mostra que a lactose é menos cariogênica do que os outros açúcares, comumente utilizados na dieta".

Com relação a associação entre o consumo de amido com a doença cárie, a qual é propalada por muitos profissionais, o autor afirma que "os alimentos cozidos que contêm amido como arroz, batata e pão parecem ter baixo 
potencial cariogênico em humanos. Estes, apesar de serem menos cariogênicos que a sacarose, quando ingeridos com frequência, podem causar cárie. E, estes produtos, quando recebem a adição de açúcar, parecem ser tão cariogênicos, quanto aqueles que contêm apenas sacarose".

Através das evidências obtidas em um número variado de fontes, RUGG-GUNN concluiu que: "O açúcar é o componente mais cariogênico de nossa dieta; está comprovado que a frequência de ingestão de açúcar é mais importante do que a quantidade consumida, sendo que repetidas ingestōes durante 0 dia, em bases regulares, são o principal fator de contribuição; o aconselhamento da dieta deveria ter como objetivo a diminuição do consumo de açúcar e o aumento de amido, de acordo com os princípios gerais de nutrição".

segundo WINKLER 92 (1991) "O açúcar é uma mercadoria importante, internacionalmente, em termos econômicos, sociais e políticos, bem como de saúde.....A atual politica sobre açúcar não tem nenhuma preocupação com a saúde. o açúcar é visto como uma questão econômica, um problema de politica agricola, de comércio agrícola ou de ajuda a programas de desenvolvimento. As consequências do açúcar sobre a saúde têm sido colocadas, exclusivamente, pelas politicas de saúde. Obesidada e doença bucal são problemas para tratamentos clínicos e programas educativos". A política do açúcar é desenvolvida, como se o super consumo nada tivesse a ver com a super produção e se, o quanto o povo consome de açúcar não tivesse nada a ver com o que isso 
custa.

HEATON $^{31}$ (1991) relata que, somente, em meados do século XIX, o açúcar tanto da cana, como da beterraba, tornou-se barato o suficiente para assumir seu lugar, atual, como maior constituinte dà dieta. É usado tão amplamente em alimentos e bebidas processados, que se tornou constituinte normal da dieta.

Entre os vários aspéctos considerados, ao se buscar explicaçōes para a persistência do alto consumo de açúcar pelas populações, destacam-se o alto capital investido pela indústria alimentícia e a relutância natural das pessoas em condenar algo de que gostam.

Feitas estas consideraçōes, neste estudo, procuramos captar se as mães possuiam algum conhecimento sobre as influências alimentares na saúde bucal, o que provavelmente, seria traduzido pela presença de hábitos alimentares saudáveis ou não.

Quando questionadas sobre o "costume" de beliscar entre as refeições principais, do total das mães, a maioria $(66,2 \%)$ assumiu possuir este hábito. Quanto ao tipo de alimento ingerido nestes momentos, os percentuais mais expressivos referiam-se a frutas, pão/bolachas/biscoitos e doces em geral (TABELA 27).

Levando-se em consideração o conhecimento cientifico existente sobre 0 assunto e o tipo de alimentos ingeridos, podemos dizer que entre as mães que possuiam o hábito de "beliscar", mais da metade apresentava um fator 
comportamental que as predispunha à cárie dentária.

Talvez, aquela parcela de mães que optava por frutas $(30,8 \%)$ tenha recebido alguma orientaçāo a este respeito, pois é de praxé nos aconselhamento alimentares efetuados por profissionais de saúde, tanto visando prevenir a cárie, como a obesidade, recomendar este tipo de alimento.

TABELA 27 - Tipo de alimento ingerido pelas mães entre refeiçōes.

\begin{tabular}{l|rc}
\hline ALIMENTO & Freq & $\%$ \\
\hline Frutas & 113 & $30.8 \%$ \\
Doces em geral & 60 & $16.3 \%$ \\
Pão/bolacha/biscoito & 107 & $29.1 \%$ \\
Salgadinhos & 8 & $2.2 \%$ \\
Café com açúcar & 12 & $3.3 \%$ \\
Outros & 67 & $18.3 \%$ \\
\hline Total & 367 & $100.0 \%$ \\
\hline
\end{tabular}

Hábitos de higiene bucal

Apesar de encontrarmos na produção científica atual, autores que afirmam que praticas de escovação dentária, estão mais associadas com a prevençāo de problemas periodontais do que da cárie, e que a importância da escovação para prevenção da cárie está mais relacionada ao valor do flúor contido nos dentifrícios, tradicionalmente, os 
dentistas têm incluído em suas orientações sobre como evitar a cárie dentária, "a escovação correta dos dentes e o uso correto do fio dental", objetivando a remoçāo da placa bacteriana causadora da cárie.

Em nosso estudo, 58,5\% das mães, isto é mais da metade, afirmaram ter sido orientadas sobre como escovar seus dentes. As fontes de orientaçōes indicadas pela maioria deste grupo foram "suas mães", $(44,4 \%)$ e o dentista particular $(31,5 \%)$. Em seguida, vieram a escola (13\%), o dentista de serviço público $(5,6 \%)$. Perceba-se que, segundo as mães, foi mínima a influÊncia da mídia (TABELA 28)

- fato de uma porcentagem considerável das entrevistadas, ter citado suas mães como principal fonte de orientaçāo sobre os cuidados de higiene bucal, confirma a importância da figura materna, na transmissão e incorporação de hábitos e práticas de saúde, desde os primeiros anos de vida do individuo. 
TABELA 28 - Fonte de orientaçāo das mães sobre a prática de escovação de seus dentes.

\begin{tabular}{l|rc}
\hline FONTE & Freq & $\%$ \\
\hline Dentista particular & 102 & $31.5 \%$ \\
Dentista serviço público & 18 & $5.6 \%$ \\
Mãe & 144 & $44.4 \%$ \\
Escola & 42 & $13.0 \%$ \\
Televisão & 2 & $0.6 \%$ \\
Outros & 16 & $4.9 \%$ \\
\hline Total & 324 & $100.0 \%$ \\
\hline
\end{tabular}

Ao procurarmos estabelecer relaçōes entre as caracteristicas sócio-econômicas das mães, visitas destas ao dentista e o fato de já terem sido orientadas sobre a prática de escovação de seus dentes, através de análise multivariada, constatamos que, as características: grupo etário, escolaridade, renda per capita, classe social e visita ao dentista, apresentaram resultados significantes, quando analisadas na associação com a variável de estudo (QUADRO 4). Contudo, após a análise de regressão logística, os fatores que, realmente, puderam ser considerados associados ao contato prévio das mães com orientações sobre a prática de escovaçāo de seus dentes foram: grupo etário, escolaridade e visita ao dentista. 
Entre as mães pertencentes ao maior grupo etário de estudo (35 a 49 anos), observamos a menor porcentagem $(44,3 \%$ ) daquelas, que já haviam sido orientadas sobre a prática de escovação; entre as idades de 25 a 29 anos estava a maior porcentagem $(64,2 \%)$.

Quanto à escolaridade das mães, foi nítido o aumento do percentual das mães que já haviam sido orientadas, acompanhando o aumento em seus nIveis de instrução. A diferença entre os percentuais observados, no nível mais baixo de escolaridade $(49,8 \%)$ e o mais alto $(83,3 \%)$ foi altamente expressiva. Mais uma vez, temos a confirmação de que o nivel educacional do paciente exerce fortes influências sobre o tipo de comunicação que o profissional irá desenvolver junto a seu paciente e vice-versa.

A análise do outro fator associado, a visita anterior da mãe ao dentista para levar um dos seus filhos menores, revelou-nos que entre aquelas mães que já haviam procurado o dentista, encontrou-se a maior proporção $(70,9 \%)$ daquelas' que já haviam sido orientadas. o que está concordante com a indicação deste profissional como fonte de orientação, por uma parcela significativa das mães.

Vale ressaltar, que nos níveis de renda mais baixos e no proletariado, situaram-se as menores porcentagens de mães que já haviam sido orientadas, 53 e 52,1\%, respectivamente. o contrário acontecendo com relação aos níveis mais altos de renda e a burguesia, onde as maiores taxas de mães orientadas foram percebidas, 75 e 68,8\%, 
respectivamente. Isto vem reafirmar, que a inserção de classe condiciona o acesso aos serviços odontológicos e à informação que os profissionais difundem através deles. 
QUADRO $\mathrm{N}^{\circ} 4$ - Total $(n)$, número(n1) e $\%$ de mães segundo contato prévio das mães com orientações sobre a prática de escovação de seus dentes, características sócio-econômicas e visita ao dentista.

\begin{tabular}{|c|c|c|c|c|c|c|}
\hline \multirow[t]{2}{*}{ CARACTERISTICAS } & \multirow{2}{*}{$\begin{array}{c}\text { TOTAL } \\
n\end{array}$} & \multicolumn{2}{|c|}{ SIM } & \multirow[t]{2}{*}{$x^{2}$} & \multirow[t]{2}{*}{$g 1$} & \multirow[t]{2}{*}{$\mathrm{p}$} \\
\hline & & $\mathrm{n} 1$ & $\%$ & & & \\
\hline $\begin{array}{l}\text { GRUPO ETÁRIO } \\
15=24 \\
25=29 \\
30=34 \\
35=49\end{array}$ & $\begin{array}{r}154 \\
190 \\
137 \\
61\end{array}$ & $\begin{array}{r}91 \\
122 \\
75 \\
27\end{array}$ & $\begin{array}{l}59,1 \\
64,2 \\
54,7 \\
44,3\end{array}$ & $8,41^{*}$ & 3 & 0,038 \\
\hline $\begin{array}{l}\text { ESCOLARIDADE } \\
\text { Analf/1 O GRAU INC. } \\
1^{\circ} \text { GRAU COMPLETO } \\
2^{\circ} \text { GRAU COMPLETO } \\
3^{\circ} \text { GRAU COMPLETO }\end{array}$ & $\begin{array}{r}255 \\
100 \\
131 \\
54\end{array}$ & $\begin{array}{r}127 \\
58 \\
86 \\
45\end{array}$ & $\begin{array}{l}49,8 \\
58,0 \\
65,6 \\
83,3\end{array}$ & $24,43^{*}$ & 3 & 0,000 \\
\hline $\begin{array}{l}\text { OCUPAÇÃO } \\
\text { Sim } \\
\text { NaO }\end{array}$ & $\begin{array}{l}206 \\
290\end{array}$ & $\begin{array}{l}124 \\
165\end{array}$ & $\begin{array}{l}60,2 \\
56,9\end{array}$ & 0,41 & 1 & 0,521 \\
\hline $\begin{array}{l}\text { RENDA PER CAPITA } \\
\text { Ate } 1 \text { sal.Min. } \\
>1 \text { a } 3 \text { Sal.Min. } \\
>3 \text { a } 10 \text { Sal.Min. }\end{array}$ & $\begin{array}{r}230 \\
207 \\
60\end{array}$ & $\begin{array}{r}122 \\
124 \\
45\end{array}$ & $\begin{array}{l}53,0 \\
59,9 \\
75,0\end{array}$ & $9,72^{*}$ & 2 & 0,008 \\
\hline $\begin{array}{l}\text { CLASSE SOCIAL } \\
\text { Burguesia } \\
\text { Proletariado } \\
\text { Subproletariado }\end{array}$ & $\begin{array}{r}189 \\
309 \\
51\end{array}$ & $\begin{array}{r}130 \\
161 \\
29\end{array}$ & $\begin{array}{l}68,8 \\
52,1 \\
56,9\end{array}$ & $13,47^{*}$ & $\star^{*} 2$ & 0,001 \\
\hline $\begin{array}{l}\text { No. FILHOS }<5 \text { ANOS } \\
1 \\
2-3\end{array}$ & $\begin{array}{l}421 \\
129\end{array}$ & $\begin{array}{r}247 \\
74\end{array}$ & $\begin{array}{l}58,7 \\
57,4\end{array}$ & 0,03 & 1 & 0,872 \\
\hline $\begin{array}{l}\text { VISITA AO DENTISTA } \\
\text { SIM } \\
\text { NÃO }\end{array}$ & $\begin{array}{l}203 \\
320\end{array}$ & $\begin{array}{l}144 \\
162\end{array}$ & $\begin{array}{l}70,9 \\
50,6\end{array}$ & $20,28+$ & +1 & 0,000 \\
\hline TOTAL & 550 & 321 & 58,4 & & & \\
\hline
\end{tabular}

REGRESSÃO LOGÍSTICA - RESULTADOS ANÁLISE DE VARIÂNCIA

\begin{tabular}{lrrl}
\hline Fonte de Variação & GL & Qui-Quad. & Prob. \\
\hline INTERCECCCÃO & 1 & 13.51 & $0.0000 *$ \\
GRUPO ETARIO & 3 & 7.97 & $0.0466 *$ \\
ESCOLARIDADE & 3 & 12.19 & $0.0068 *$ \\
CLASSE SOCIAL & 2 & 3.47 & 0.1762 \\
VISITA AO DENTISTA & 1 & 13.20 & $0.0003 *$ \\
RAZÃO DE MAXIMO- & 68 & 76.16 & 0.2326
\end{tabular}

VEROSSIMILHANÇA

(*) Significante ao nível de $5 \%$. 


\section{Procura pelo dentista}

Ao explorarmos a questão da procura de ajuda profissional, verificamos que a maioria das mães do estudo (cerca de $60 \%$ ), só procurava o dentista quando sentia haver necessidade ou seja, quando algum problema bucal chegava a incomodá-las. No entanto, havia entre o total destas māes, uma parcela significativa (29\%), que o procurava por motivos preventivos: "controle, revisão, limpeza, e preservação dos dentes" (TABELA 29).

TABELA 29 - Motivo habitual da procura ao dentista pelas mães

\begin{tabular}{l|rc}
\hline MOTIVo & Freq & $\%$ \\
\hline Necessidade/problemas & 331 & $59.7 \%$ \\
Prevenção & 161 & $29.1 \%$ \\
Outros & 60 & $10.8 \%$ \\
Não respondeu & 2 & $0.4 \%$ \\
\hline Total & 554 & $100.0 \%$ \\
\hline
\end{tabular}

Ao ponderarmos sobre o fato de que a maioria das mães pertencia às classes mais baixas, podemos dizer que, estes resultados estão de acordo com as afirmativas de BOLTANSKI" (1989), "Para os membros das classes populares, que não prestam voluntariamente atenção ao seu corpo, que o usam principalmente como um instrumento, que lhes pedem antes de mais nada que funcione, em resumo, que subordinam a utilização do corpo às funções sociais dessa utilização, a 
doença se manifestará brutalmente, porque não se aperceberam dos sinais precursores ou porque se recusaram a percebê-1os; a doença será vista o mais das vezes como um acidente imprevisivel e súbito. Inversamente, os membros das classes superiores que prestam atenção ao corpo e têm uma percepção aguçada de suas mensagens, e para os quais as pequenas sensaçōes de doença são coisas costumeiras e banais, nāo estabelecem uma diferença tão definida entre o estado de saúde e o estado de doença, se bem que tenham tendência a ver na doença uma espécie de previsão longa e irrisória da saúde, em vez de um acidente súbito. A doença para estes tem uma história, um começo muitas vezes invisivel, uma evolução, um fim, consequências. Inscreve-se no tempo. Assim, os membros das classes superiores adotam em relação a doença uma atitude de previsão seja porque buscam, no presente, os sinais precursores de doenças que ainda não se manifestaram brutalmente, seja porque se submetem a um certo número de regras que visam a preservá-los de serem atingidos pela doença". 


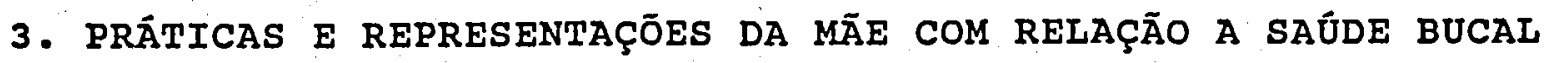
DA CRIANÇA PEQUENA.

\subsection{Práticas alimentares da mãe em relação a criança e algumas representaçōes da relação com a saúde bucal infantil.}

o tipo de alimentação da criança pequena, desde seu nascimento é definido pela mãe. Primeiramente, através do aleitamento e do fornecimento de mamadeiras; depois com a introdução gradativa de alimentos sólidos até a incorporação pela criança dos hábitos alimentares familiares. Durante este periodo, a mãe conduz suas práticas alimentares com a criança, de acordo com influências culturais, familiares, conselhos médicos e outras, próprias de sua condição social.

Como visto, anteriormente, os hábitos alimentares estão estreitamente relacionados com o processo saúde-doença bucal. Sendo que, quando inadequados, constituem-se em um dos fatores de risco para o desenvolvimento da cárie dentária.

Procuramos, assim, dentro deste tópico, conhecer as práticas alimentares que as mães de nosso estudo vinham assumindo em relação a seus filhos menores e identificar prováveis relações entre estas e o risco que as crianças apresentavam de ter cárie.

De acordo com WALTER e col. ${ }^{85}$ (1985) "os fatores ambientais e nāo ambientais que determinam o maior ou menor risco de um bebê vir a adquirir a cárie dentária, podem ser 
resumidos em cinco grandes fatores: dois não ambientais e três ambientais ou culturais".

Entre os não ambientais temos: presença na boca de dentes susceptrveis e, contaminação da criança pelo estreptococos mutans, através de seus familiares. E os ambientais incluem: a ausência do hábito precoce de higienização e escovação dental; a presença de hábitos alimentares inadequados, relacionados com a amamentação, principalmente a noturna e o alto consumo de carboidratos.

Este autor, afirma que "a eliminação dos fatores de risco ambientais, mais fáceis, levam a uma redução da cárie dentária em cerca de $60 \%$, principalmente, quando somada a outros procedimentos destinados a aumentar a resistência dos dentes (aplicação de flúor tópico caseiro)".

Hábito de mamadeira noturna

Quando ocorre a erupção dos primeiros dentes no bebê, por volta dos 6 meses de idade, esta coincide com a presença de hábitos alimentares à base de leite e ausência da higiene oral, na maioria dos bebês, sendo ambos fatôres prejudiciais à saúde bucal da criança.

Em nosso estudo, foi confirmado pelas mães, que a maioria de seus filhos (cerca de $70 \%$ das crianças) apresentavam o hábito de tomar mamadeira ao dormir ou durante à noite; $8.2 \%$ usavam mamadeira apenas durante 0 dia e $14.7 \%$ das crianças, estavam recebendo o aleitamento materno (TABELA 
30).

TABELA 30 - Distribuição dos filhos menores de 5 anos de idade segundo o hábito de mamadeira noturna.

\begin{tabular}{l|rc}
\hline HÁBITO & Freq & \multicolumn{1}{c}{$\%$} \\
\hline NĀO & 57 & $8.2 \%$ \\
SIM & 485 & $69.9 \%$ \\
ALEITAMENTO MATERNO & 102 & $14.7 \%$ \\
NÃO RESPONDEU & 49 & $7.2 \%$ \\
\hline Total & 693 & $100.0 \%$ \\
\hline
\end{tabular}

A análise multivariada entre a associação do hábito de mamadeira noturna e as caracteristicas sócio-econômicas maternas, revelou-nos que a escolaridade e o número de filhos pequenos apresentaram resultados, estatísticamente, significantes (QUADRO 5).

Entre as mães que possuiam $\circ 3^{\circ}$ grau completo e as que tinham apenas um filho pequeno, registraram-se as maiores porcentagens $(91,3$ e $93,5 \%)$ de crianças que apresentavam 0 hábito de mamadeira noturna. Após a regressão logística, o fator que permaneceu associado ao uso de mamadeira noturna foi o número de filhos pequenos.

Através das variáveis estudadas, podemos dizer que, independentemente, da idade, do fato de trabalhar ou não, do nivel de renda, da classe social a que pertença, de já ter levado um de seus filhos pequenos ao dentista, e até do nivel de escolaridade da mãe, altas porcentagens das crianças de 
nosso estudo apresentavam o hábito da mamadeira noturna, ou seja estavam expostas a um fator de risco à cárie dentária.

A ansiedade da criança se alimentar, a facilidade de dar mamadeira à criança, enquanto esta dorme, sem possibilidades de recusa, o cansaço em lidar com a rebeldia da criança, a presença de ambas, mãe e criança em casa, deviam estar reforçando a introdução e a manutenção, generalizada, deste hábito. 
QUADRO $\mathrm{N}^{\circ} 5$ - Total(n), número(n1) e $\%$ de crianças que usam mamadeira noturna segundo caracteristicas sócio-economicas e visita ao dentista.

\begin{tabular}{|c|c|c|c|c|c|c|}
\hline CARACTERISTICAS & $\begin{array}{c}\text { TOTAL } \\
n\end{array}$ & $\begin{array}{l}\text { MAM } \\
\text { NOT } \\
\mathrm{n}\end{array}$ & $\begin{array}{l}\text { EIRA } \\
\text { NA } \%\end{array}$ & $x^{2}$ & gl & $\mathrm{p}$ \\
\hline $\begin{array}{l}\text { GRUPO ETÁRIO } \\
15-24 \\
25=29 \\
30-34 \\
35-49\end{array}$ & $\begin{array}{l}140 \\
195 \\
130\end{array}$ & $\begin{array}{l}127 \\
173 \\
120\end{array}$ & $\begin{array}{l}90,7 \\
88,7 \\
92,3\end{array}$ & 1,92 & 3 & 0,588 \\
\hline $\begin{array}{l}\text { ESCOLARIDADE } \\
\text { Analf/10 GRAUINC. } \\
10 \text { GRAU COMPLETO } \\
\text { 20 GRAU COMPLETO } \\
\text { 30 GRAU COMPLETO }\end{array}$ & $\begin{array}{r}238 \\
89 \\
123 \\
69\end{array}$ & $\begin{array}{r}207 \\
77 \\
118 \\
63\end{array}$ & $\begin{array}{l}87,0 \\
86,5 \\
95,9 \\
91,3\end{array}$ & $8,18^{*}$ & 3 & 0,043 \\
\hline $\begin{array}{l}\text { OCUPAÇĀo } \\
\text { Sim } \\
\text { NaO }\end{array}$ & $\begin{array}{l}197 \\
276\end{array}$ & $\begin{array}{l}179 \\
246\end{array}$ & $\begin{array}{l}90,9 \\
89,1\end{array}$ & 0,21 & 1 & 0,645 \\
\hline $\begin{array}{l}\text { RENDA PER CAPITA } \\
\text { Ate } 1 \text { sal.Min. } \\
>1 \text { a } 3 \text { Sal.Min. } \\
>3 \text { a } 10 \text { Sal.Min. }\end{array}$ & $\begin{array}{r}228 \\
186 \\
64\end{array}$ & $\begin{array}{r}203 \\
171 \\
56\end{array}$ & $\begin{array}{l}89,0 \\
91,4 \\
87,5\end{array}$ & 1,06 & 2 & 0,588 \\
\hline $\begin{array}{l}\text { CLASSE SOCIAL } \\
\text { Burguesia } \\
\text { Proletariado } \\
\text { Subproletariado }\end{array}$ & $\begin{array}{r}191 \\
289 \\
51\end{array}$ & $\begin{array}{r}173 \\
256 \\
47\end{array}$ & $\begin{array}{l}90,6 \\
88,6 \\
92,2\end{array}$ & 0,88 & 2 & 0,645 \\
\hline $\begin{array}{l}\text { VISITAS DENTISTA } \\
\text { Sim } \\
\text { Não }\end{array}$ & $\begin{array}{l}202 \\
314\end{array}$ & $\begin{array}{l}177 \\
284\end{array}$ & $\begin{array}{l}87,6 \\
90,4\end{array}$ & 0,75 & 1 & 0,386 \\
\hline $\begin{array}{l}\text { NO. FILHOS }<5 \text { ANOS } \\
1 \\
2-3\end{array}$ & $\begin{array}{l}309 \\
222\end{array}$ & $\begin{array}{l}289 \\
187\end{array}$ & $\begin{array}{l}93,5 \\
84,2\end{array}$ & $11,04 *$ & 1 & 0,001 \\
\hline TOTAL & 542 & 485 & 89,5 & & & \\
\hline
\end{tabular}

REGRESSÃO LOGÍSTICA - RESULTADOS ANÁLISE DE VARIÂNCIA

\begin{tabular}{lcrc}
\hline Fonte de Variação & GL & Qui-Quad. & Prob. \\
\hline INTERCECÇÃO & 1 & 157.34 & $0.0000 *$ \\
ESCOLARIDADE & 3 & 7.16 & 0.0670 \\
NO.FILHOS S5ANOS & 1 & 11.70 & 0.0006 \\
RAZÃO DE MAXIMO- & 3 & 4.68 & 0.1969 \\
VEROSSIMILHANÇA & & & \\
\hline
\end{tabular}

(*) Significante ao nível de $5 \%$ 
Inquerimos das mães que relataram que seus filhos faziam o uso de mamadeira, independente do fato de ser durante o dia e/ou à noite, (total de 542 crianças), se estas acrescentavam alguma substância ao leite. Como resposta, tivemos que a maioria destas crianças $(85,1 \%)$ recebia mamadeira com adição de alguma substância, além do leite. Ao procedermos a análise multivariada (QUADRO 8), 0 único fator associado à introdução de substâncias ao leite por parte das mães foi o nivel de escolaridade destas. As menores porcentagens $(79,6$ e $77,4 \%)$ de crianças que recebiam adição de substâncias à mamadeira estavam entre as mães de nivel de escolaridade mais baixo e aquelas com maior idade, apesar desta última variável não ter apresentado resultado significante na associação.

De uma forma geral, todas as mães acrescentavam substâncias à mamadeira de seus filhos, independentemente da idade, ocupação, renda, classe social, número de filhos pequenos e do fato de já ter levado um de seus filhos menores ao dentista. 
QUADRO $\mathrm{N}^{\circ} 6$ - Total(n), número(n1) e \% de crianças que usam substancias na mamadeira segundo caracteristicas sócioeconomicas.

\begin{tabular}{|c|c|c|c|c|c|c|}
\hline CARACTERISTICAS & $\begin{array}{c}\text { TOTAL } \\
n\end{array}$ & $\begin{array}{l}\text { USAM } \\
\mathrm{n}(1)\end{array}$ & $\%$ & $x^{2}$ & gl & $p$ \\
\hline $\begin{array}{l}\text { GRUPO ETÁRIO } \\
15-24 \\
25-29 \\
30-34 \\
35-49\end{array}$ & $\begin{array}{r}139 \\
194 \\
130 \\
62\end{array}$ & $\begin{array}{r}118 \\
172 \\
111 \\
48\end{array}$ & $\begin{array}{l}84,9 \\
88,7 \\
85,4 \\
77,4\end{array}$ & 4,88 & 3 & 0,181 \\
\hline $\begin{array}{l}\text { ESCOLARIDADE } \\
\text { Analf/10 GRUA INC. } \\
\text { 10 GRAU COMPLETO } \\
\text { 20 GRAU COMPLETO } \\
\text { 30 GRAU COMPLETO }\end{array}$ & $\begin{array}{r}240 \\
91 \\
121 \\
67\end{array}$ & $\begin{array}{r}191 \\
84 \\
109 \\
58\end{array}$ & $\begin{array}{l}79,6 \\
92,3 \\
90,1 \\
86,6\end{array}$ & $12,01 *$ & 3 & 0,007 \\
\hline $\begin{array}{l}\text { OCUPAÇÃo } \\
\text { Sim } \\
\text { Não }\end{array}$ & $\begin{array}{l}194 \\
280\end{array}$ & $\begin{array}{l}167 \\
240\end{array}$ & $\begin{array}{l}86,1 \\
85,7\end{array}$ & 0,00 & 1 & 0,983 \\
\hline $\begin{array}{l}\text { RENDA PER CAPITA } \\
\text { Ate } 1 \text { sal.Min. } \\
>1 \text { a } 3 \text { Sal.Min. } \\
>3 \text { a } 10 \text { Sal.Min. }\end{array}$ & $\begin{array}{r}233 \\
186 \\
62\end{array}$ & $\begin{array}{r}195 \\
163 \\
52\end{array}$ & $\begin{array}{l}83,7 \\
87,6 \\
83,9\end{array}$ & 1,38 & 2 & 0,501 \\
\hline $\begin{array}{l}\text { CLASSE SOCIAL } \\
\text { Burguesia } \\
\text { Proletariado } \\
\text { Subproletariado }\end{array}$ & $\begin{array}{r}187 \\
294 \\
50\end{array}$ & $\begin{array}{r}162 \\
244 \\
46\end{array}$ & $\begin{array}{l}86,6 \\
83,0 \\
92,0\end{array}$ & 3,26 & 2 & 0,196 \\
\hline $\begin{array}{l}\text { VISITA AO DENTISTA } \\
\text { Sim } \\
\text { Não }\end{array}$ & $\begin{array}{l}198 \\
316\end{array}$ & $\begin{array}{l}164 \\
273\end{array}$ & $\begin{array}{l}82,8 \\
86,4\end{array}$ & 0,95 & 1 & 0,329 \\
\hline $\begin{array}{l}\text { No. FILHOS } \angle 5 \text { ANOS } \\
1 \\
2-3\end{array}$ & $\begin{array}{l}308 \\
223\end{array}$ & $\begin{array}{l}262 \\
190\end{array}$ & $\begin{array}{l}85,1 \\
85,2\end{array}$ & 0,01 & 1 & 0,936 \\
\hline TOTAL & 542 & 461 & 85,1 & & & \\
\hline
\end{tabular}

(*) Significante ao nível de $5 \%$. 
As substancias acrescidas e o motivo do acréscimo estão identificados nas TABELAS 31 e 32 .

Achocolatado, açúcar e mel estavam entre as substâncias mais usadas pelas mães, que alegavam utilizá-las, principalmente, para facilitar a aceitação da criança $(42,3 \%)$ e fortalecimento do leite (18\%).

Encontramos as seguintes "falas"a este respeito: as mães colocam algo no leite...

"Para tornar o sabor mais agradável... A criança não gosta de leite puro... leite puro não tem sabor... é dificil tomar sem açúcar".

"Para sustentar mais... ficar mais forte reforcar a alimentação... engrossar... complementar... ficar mais nutritivo".

Nas representaçōes e práticas maternas, com relaçāo à amamentação dos bebês, fica claro que estas não percebem nenhuma associação entre esta prática e a saúde bucal da criança, estando mais preocupadas em resolver sua ansiedade com relação a aspéctos nutritivos, mesmo que através de mecanismos inadequados.

Apesar de os conhecimentos cientificos médicos apontarem para inexistência de "leite fraco", as mães continuam tentando fortalecê-lo, com o acréscimo de substâncias. Além disso, elas acabam definindo o paladar do bebê, pela sua própria preferência pelos alimentos doces. 
TABELA 31 - Distribuiçāo dos filhos segundo substância acrescida à mamadeira pelas mães.

\begin{tabular}{l|rr}
\hline SUBSTÁNCIA & Freq & $\%$ \\
\hline Açúcar & 79 & $17.1 \%$ \\
Mel & 14 & $3.0 \%$ \\
Adoçante & 4 & $0.9 \%$ \\
Maizena & 62 & $13.4 \%$ \\
Achocolatado & 124 & $26.8 \%$ \\
Aleitamento materno & 10 & $2.2 \%$ \\
Outros & 169 & $36.6 \%$ \\
\hline Total & 462 & $100.0 \%$ \\
\hline
\end{tabular}

TABELA 32 - Motivo do acréscimo de substâncias à mamadeira segundo as mães.

\begin{tabular}{l|rc}
\hline MOTIVO & Freq & $\%$ \\
\hline FORTALECIMENTO DO LEITE & 83 & $18.0 \%$ \\
ACEITAÇÃO DA CRIANÇA & 195 & $42.3 \%$ \\
SAÚDE DA CRIAÇA & 32 & $7.0 \%$ \\
RECOMENDAÇÃO DO PEDIATRA & 17 & $3.7 \%$ \\
HÁBITOS & 20 & $4.3 \%$ \\
OUTROS & 11 & $2.4 \%$ \\
NĀO RESPONDEU & 103 & $22.3 \%$ \\
\hline Total & 461 & $100.0 \%$ \\
\hline
\end{tabular}




\section{Hábito de "beliscar" entre as refeiçōes}

Exploramos, também, em nosso estudo se as crianças pequenas apresentavam o hábito de comer várias vezes, nos intervalos entre as refeiçōes principais. Constatamos que, a maioria delas ( $82.4 \%)$, aprésentava o hábito de "beliscar" entre as refeiçōes. E, que os alimentos por elas preferidos eram na seguinte ordem de proporçāo: bolachas/pão (48\%); doces $(18.6 \%)$, frutas $(15 \%)$, vindo a seguir em porcentagens bem menores, salgadinhos, danone, iogurte, legumes crus, entre outros citados pelas mães.

A análise multivariada apontou a escolaridade da mãe, como único fator associado a este hábito da criança (QUADRO 9). Encontramos porcentagens semelhantes de filhos com o hábito; entre as mães com $1^{\circ}$ grau incompleto, $1^{\circ} \mathrm{grau}$ completo e $3^{\circ}$ grau completo $(80.1 ; 79.8$ e $78.1 \%)$. Observe-se que esta diferença, embora pequena, foi significativa. 0 maior percentual das crianças, encontrou-se entre as mães com $2^{\circ}$ grau completo $(90.8 \%)$.

Entre as māes com diferentes idades, ocupações, níveis de renda, posições de classe, $n^{\circ}$ de filhos pequenos e que já haviam ou não levado um de seus filhos pequenos ao dentista, nāo variou a alta proporção de crianças com o hábito de "beliscar"entre as refeiçōes. 
QUADRO $N^{\circ} 7$ - Total $(n)$, número(nI) e \% de crianças segundo hábito de beliscar e características sócio-econômicas.

\begin{tabular}{|c|c|c|c|c|c|c|}
\hline CARACTERISTICAS & $\underset{n}{\text { TOTAL }}$ & $\begin{array}{l}\mathrm{HAB} \\
\mathrm{n} 1\end{array}$ & $\begin{array}{l}\text { ISCAR } \\
\%\end{array}$ & $x^{2}$ & gl & $p$ \\
\hline $\begin{array}{l}\text { GRUPO ETÁRIO } \\
\begin{array}{l}15-24 \\
25-29 \\
30-34 \\
35-49\end{array}\end{array}$ & $\begin{array}{r}165 \\
218 \\
156 \\
69\end{array}$ & $\begin{array}{r}136 \\
177 \\
128 \\
59\end{array}$ & $\begin{array}{l}82,4 \\
81,2 \\
82,1 \\
85,5\end{array}$ & 0,68 & 3 & 0,879 \\
\hline $\begin{array}{l}\text { ESCOLARIDADE } \\
\text { AnaIf/1 } \\
1^{\circ} \text { GRAU COMPU INC. } \\
2^{\circ} \text { GRAU COMPLETO } \\
3^{\circ} \text { GRAU COMPLETO }\end{array}$ & $\begin{array}{r}287 \\
109 \\
142 \\
64\end{array}$ & $\begin{array}{r}230 \\
87 \\
129 \\
50\end{array}$ & $\begin{array}{l}80,1 \\
79,8 \\
90,8 \\
78,1\end{array}$ & $9,30^{*}$ & 3. & 0,026 \\
\hline $\begin{array}{l}\text { OCUPAÇĀo } \\
\text { Sim } \\
\text { Não }\end{array}$ & $\begin{array}{l}226 \\
327\end{array}$ & $\begin{array}{l}181 \\
275\end{array}$ & $\begin{array}{l}80,1 \\
84,1\end{array}$ & 1,22 & 1 & 0,269 \\
\hline $\begin{array}{l}\text { RENDA PER CAPITA } \\
\text { Ate } 1 \text { sal.Min. } \\
>1 \text { a } 3 \text { Sal.Min. } \\
>3 \text { a } 10 \text { Sal.Min. }\end{array}$ & $\begin{array}{r}264 \\
223 \\
70\end{array}$ & $\begin{array}{r}221 \\
185 \\
59\end{array}$ & $\begin{array}{l}83,7 \\
83,0 \\
84,3\end{array}$ & 0,09 & 2 & 0,957 \\
\hline $\begin{array}{l}\text { CLASSE SOCIAL } \\
\text { Burguesia } \\
\text { Proletariado } \\
\text { Subproletariado }\end{array}$ & $\begin{array}{r}213 \\
339 \\
61\end{array}$ & $\begin{array}{r}178 \\
279 \\
48\end{array}$ & $\begin{array}{l}83,6 \\
82,3 \\
78,7\end{array}$ & 0,78 & 2 & 0,677 \\
\hline $\begin{array}{l}\text { NO. FILHOS }<5 \text { ANOS } \\
1 \\
2-3\end{array}$ & $\begin{array}{l}384 \\
230\end{array}$ & $\begin{array}{l}316 \\
190\end{array}$ & $\begin{array}{l}82,3 \\
82,6\end{array}$ & 0,00 & 1 & 0,992 \\
\hline $\begin{array}{l}\text { VISITA AO DENTISTA } \\
\text { SIM } \\
\text { NÄO }\end{array}$ & $\begin{array}{l}250 \\
344\end{array}$ & $\begin{array}{l}207 \\
284\end{array}$ & $\begin{array}{l}82,8 \\
82,6\end{array}$ & 0,00 & 1 & 0,169 \\
\hline TOTAL & 614 & 506 & 82,4 & & & \\
\hline
\end{tabular}

(*) Significante ao nível de $5 \%$ 
Apesar de, anteriormente, terem afirmado que a maioria de seus filhos pequenos apresentava o hábito de comer entre as refeições principais, $34,1 \%$ destas, negaram que alguém oferecesse os alimentos à criança. Somente $44,4 \%$ disseram que os pequenos, recebiam os alimentos de alguém, sendo a principal responsável por esta oferta, a própria mãe (TABELAS 33 e 34 ).

TABELA 33 - Distribuição das mães segundo a oferta de alimentos entre as refeições aos filhos.

\begin{tabular}{l|rc}
\hline OFERTA & Freq & $\%$ \\
\hline NÃO & 189 & $34.1 \%$ \\
SIM & 246 & $44.4 \%$ \\
HÁBITO AUSENTE & 57 & $10.3 \%$ \\
ALEITAMENTO MATERNO & 62 & $11.2 \%$ \\
\hline TOtaI & 554 & $100.0 \%$ \\
\hline
\end{tabular}

TABELA 34 - Pessoas que oferecem alimentos entre refeições aos filhos.

\begin{tabular}{l|rc}
\hline PESSOAS & Freq & \multicolumn{1}{c}{$\%$} \\
\hline A própria mãe & 158 & $64.2 \%$ \\
O pai & 8 & $3.3 \%$ \\
Todos da família & 30 & $12.2 \%$ \\
Avós & 26 & $10.6 \%$ \\
Empregada/babá & 9 & $3.7 \%$ \\
Outros & 15 & $6.1 \%$ \\
\hline Total & 246 & $100.0 \%$ \\
\hline
\end{tabular}


A maioria das mães das crianças que comiam, frequentemente, entre as refeiçōes principais (46.7\%), consideravam tal comportamento " bom para a saúde" ou, simplesmente, como "algo normal" (13.3\%). Por outro lado, 32\% destas disseram ser "prejudicial" (TABELA 35)

TABELA 35 - Opinião das mães sobre o hábito de seus filhos de "beliscar" entre refeiçōes.

\begin{tabular}{l|rc}
\hline OPINIÃO & Freq & $\%$ \\
\hline NORMAL & 58 & $13.3 \%$ \\
BOM PARA A SAÚDE & 203 & $46.7 \%$ \\
RUIM & 139 & $32.0 \%$ \\
NĀO SABE & 13 & $3.0 \%$ \\
OUTROS & 9 & $2.0 \%$ \\
NÃO RESPONDEU & 13 & $3.0 \%$ \\
\hline Total & 435 & $100.0 \%$ \\
\hline
\end{tabular}

Do total de mães investigadas que confirmaram que seus filhos apresentaram este hábito (435), apenas, cerca de $20 \%$ disseram que estavam procurando removê-lo, através das condutas expressas na TABELA 36, havendo o predomínio de atividades proibitivas $(48,9 \%)$. 
TABELA 36 - Tipo de conduta das mães para remoção do hábito de "beliscar" entre as refeiçōes dos filhos.

\begin{tabular}{l|rr}
\hline CoNDUTA & Freq & \multicolumn{1}{c}{$\%$} \\
\hline Educação & 24 & $26.7 \%$ \\
Substituição alimentos cariogênicos & 14 & $15.6 \%$ \\
Proibição & 44 & $48.9 \%$ \\
Outros & 8 & $8.9 \%$ \\
\hline Total & 90 & $100.0 \%$ \\
\hline
\end{tabular}

\subsection{Prāticas e representaçōes da mãe sobre a higiene} bucal da criança

Através dos vários autores que citamos, ficou explicito que corretas práticas de higiene bucal, desde o nascimento dos primeiros dentes do bebê, são decisivas para promoção da saúde bucal infantil.

WALTER e cols. 85 (1985) recomendam para limpeza da boca e dos dentes dos bebês: "dissolver 1 colher de sopa de água oxigenada 10 volumes em 4 colheres de água fervida; usar ponta de fralda ou 1 cotonete para limpeza dos dentes e da boca, inclusive a lingua, no mínimo uma vez por dia; após os 18 meses de idade, substituir a limpeza pela escovação dos dentes". 
KWON e GUEDES-PINTO ${ }^{37}$ (1988) ao abordar os objetivos da escovação dental, destacam a remoção diária da placa dental, como um procedimento básico para prevenção e cura das doenças bucais (cárie e doença periodontal). Indicam que o inf́cio da escovação dental deva ser feito o mais cedo possivel, desde que a criança aceite esta prática. Aconselham que os pais devem escovar seus próprios dentes na presença dos filhos, para despertar-lhes a curiosidade, principalmente, dos mais novos, com menos de 2 anos de idade. Em etapa posterior, devem dar uma escova infantil para que a criança possa imitá-los. Depois, gradativamente, devem escovar os dentes da criança, até a aceitação desta.

Os autores dizem ser importante "lembrarmos à familia que a criança deve associar a limpeza dos dentes, como complemento da alimentação e chamando a atenção, também, que o hábito deve ser cultivado, como medida de saúde e não como simples consideraçōes cosméticas de efeito estético".

Na clínica odontopediátrica, aconselha-se que a mãe ou o responsável é quem deve escovar os dentes da criança em idade pré-escolar, pelo menos uma vez por dia, de preferência à noite, antes desta dormir. Nas outras ocasiões, deve, pelo menos, supervisionar a escovação efetuada pela criança.

As análises que se seguem procuram situar como as māes, nossa população de estudo, vivenciam e interpretam os cuidados higiênicos, em relação a seus filhos menores. 
Época da primeira limpeza dos dentes da criança pequena pela māe

A maior porcentagem das crianças de nosso estudo $(58,7 \%)$, teve a primeira limpeza de seus dentes efetuada por suas mães, em épocas consideradas incorretas, como: "quando a criança já tinha todos os dentes na boca.... após 1 ano de idade... após 2 anos de idade".

Através da análise multivariada, verificamos que associadas à prática incorreta da mãe com relação à limpeza dos dentes de seus filhos, estavam as seguintes caracteristicas: escolaridade, ocupação, renda e o fato de já ter levado um de seus filhos menores ao dentista.

Entre as mães de $3^{\circ}$ grau completo, que trabalhavam, com renda entre 1 a 3 salários minimos e que já haviam levado um de seus filhos pequenos ao dentista, registraram-se as menores porcentagens de crianças que haviam recebido a primeira limpeza de seus dentes, em época inapropriada (QUADRO 10).

A análise de regressão logística permitiu considerar como fator relacionado à variável de estudo, apenas a ocupação da mãe. Este achado merece, comentário, pois entre as mães que não trabalhavam, permanecendo em casa, encontramos a maior proporção de filhos (63\%), nos quais a prática estudada foi incorreta. Fato que deve estar associado ao menor nível de instrução, bem como a posições sociais mais inferiores destas. 
QUADRO $\mathrm{N}^{\circ} 8$ - Total(n), número(nl) e \% de crianças com época incorreta para primeira limpeza dos dentes segundo características sócio-economicas e visita ao dentista

\begin{tabular}{|c|c|c|c|c|c|c|}
\hline CARACTERISTICAS & $\begin{array}{c}\text { TOTAL } \\
n\end{array}$ & $\begin{array}{l}\text { EPOC } \\
\text { INCC } \\
\text { nI }\end{array}$ & $\begin{array}{r}\text { ETA } \\
\%\end{array}$ & $x^{2}$ & $g l$ & $\mathrm{p}$ \\
\hline $\begin{array}{l}\text { GRUPO ETÁRIO } \\
15-24 \\
25-29 \\
30-34 \\
35-49\end{array}$ & $\begin{array}{r}147 \\
201 \\
141 \\
61\end{array}$ & $\begin{array}{r}86 \\
119 \\
75 \\
43\end{array}$ & $\begin{array}{l}58,5 \\
59,2 \\
53,2 \\
70,5\end{array}$ & 5,29 & 2 & 0,152 \\
\hline $\begin{array}{l}\text { ESCOLARIDADE } \\
\text { Analf/1 } \\
1^{\circ} \text { GRAU COMPLETO } \\
2^{\circ} \text { GRAU COMPLETO } \\
3^{\circ} \text { GRAU COMPLETO }\end{array}$ & $\begin{array}{r}249 \\
98 \\
133 \\
65\end{array}$ & $\begin{array}{r}150 \\
66 \\
73 \\
30\end{array}$ & $\begin{array}{l}60,2 \\
67,3 \\
54,9 \\
46,2\end{array}$ & $8,27^{\star}$ & 3 & 0,041 \\
\hline $\begin{array}{l}\text { OCUPAÇĀo } \\
\text { Sim } \\
\text { Nao }\end{array}$ & $\begin{array}{l}206 \\
292\end{array}$ & $\begin{array}{l}104 \\
184\end{array}$ & $\begin{array}{l}50,5 \\
63,0\end{array}$ & $7,77^{*}$ & 1 & 0,005 \\
\hline $\begin{array}{l}\text { RENDA PER CAPITA } \\
\text { Ate } 1 \text { sal.Min. } \\
>1 \text { a } 3 \text { Sal.Min. } \\
>3 \text { a } 10 \text { Sal.Min. }\end{array}$ & $\begin{array}{r}242 \\
199 \\
67\end{array}$ & $\begin{array}{r}157 \\
105 \\
36\end{array}$ & $\begin{array}{l}64,9 \\
52,8 \\
53,7\end{array}$ & $7,38^{\star}$ & 2 & 0,025 \\
\hline $\begin{array}{l}\text { CLASSE SOCIAL } \\
\text { Burguesia } \\
\text { Proletariado } \\
\text { Subproletariado }\end{array}$ & $\begin{array}{r}206 \\
295 \\
53\end{array}$ & $\begin{array}{r}111 \\
183 \\
32\end{array}$ & $\begin{array}{l}53,9 \\
62,0 \\
60,4\end{array}$ & 3,38 & 2 & 0,184 \\
\hline $\begin{array}{l}\text { VISITAS AO DENTIST } \\
\text { Sim } \\
\text { Não }\end{array}$ & $\begin{array}{l}210 \\
329\end{array}$ & $\begin{array}{l}108 \\
205\end{array}$ & $\begin{array}{l}51,4 \\
62,3\end{array}$ & $6,23^{\star}$ & 1 & 0,013 \\
\hline $\begin{array}{l}N^{0} . \text { FILHOS }<5 \text { ANOS } \\
2-3\end{array}$ & $\begin{array}{l}335 \\
220\end{array}$ & $\begin{array}{l}192 \\
134\end{array}$ & $\begin{array}{l}57,3 \\
60,9\end{array}$ & 0,71 & 1 & 0,399 \\
\hline TOTAL & 555 & 326 & 58,7 & & & \\
\hline
\end{tabular}

REGRESSÃO LOGÍISTICA - RESULTADOS ANÁLISE DE VARIÂNCIA

\begin{tabular}{lcrc}
\hline Fonte de Variação & GL & Qui- Quad. & Prob. \\
\hline INTERCECÇĀO & 1 & 2.17 & 0.1412 \\
OCUPAÇÃO & 1 & 6.56 & $0.0104 *$ \\
ESCOLARIDADE & 3 & 5.88 & 0.1178 \\
RENDA PER CAPITA & 2 & 1.43 & 0.4880 \\
VISITA AO DENTISTA & 1 & 3.71 & 0.0540 \\
RAZÃO DE MAXIMO- & 35 & 42.34 & 0.1838 \\
VEROSSIMILHANÇA & & &
\end{tabular}

(*) Significante ao nível de $5 \%$. 
orientaçāo da māe sobre os primeiros cuidados com a higiene bucal da criança

A maioria das mães do estudo, que já havia limpado os dentes de seus filhos $(47,8 \%)$, afirmou não ter sido orientada sobre os primeiros cuidados com a higiene bucal de seus filhos menores (TABELA 37).

TABELA 37 - Orientação materna sobre os primeiros cuidados com a higiene bucal de seus filhos.

\begin{tabular}{l|rc}
\hline ORIENTAÇÃO & Freq & $\%$ \\
\hline NÃO & 265 & $47.8 \%$ \\
SIM & 151 & $27.3 \%$ \\
AINDA NÃO LIMPOU & 138 & $24.9 \%$ \\
\hline Total & 554 & $100.0 \%$ \\
\hline
\end{tabular}

As fontes de orientação materna apontadas foram: dentista particular, médico particular, dentista de serviço público, sua própria mãe, médico de serviço público e leituras diversas (TABELA 38).

$$
\text { Perceba-se a importância da integração }
$$

multiprofissional, no caso, o médico atuando como um importante agente difusor de informaçōes sobre a higiene bucal. 
TABELA 38 - Fonte de orientação das mães sobre a limpeza dos dentes dos filhos.

\begin{tabular}{l|rc}
\hline FONTE & Freq & \multicolumn{1}{c}{$\%$} \\
\hline Mãe (avó da criança) & 14 & $9.3 \%$ \\
Leituras diverșas & 5 & $3.3 \%$ \\
Dentista particular & 44 & $29.1 \%$ \\
Dentista serviço-público & 25 & $16.6 \%$ \\
Médico particular & 26 & $17.2 \%$ \\
Médico serviço-público & 8 & $5.3 \%$ \\
Outros & 29 & $19.2 \%$ \\
\hline Total & 151 & $100.0 \%$ \\
\hline
\end{tabular}

Escolaridade, ocupação, classe social e visita ao dentista, foram as variáveis associadas ao fato de as mães não terem sido orientadas, que apresentaram resultados estatisticamente significantes quando relacionadas com ele (QUADRO 11).

As taxas mais expressivas de mães, que não receberam orientações sobre os primeiros cuidados com a higiene bucal de seus filhos, encontraram-se entre os grupos de mães com $\circ 1^{\circ}$ grau incompleto $(74,1 \%)$, que não trabalhavam $(69,4 \%)$, integrantes de famílias com renda "per capita" até 1 salário mínimo $(69,9 \%)$, pertencentes ao proletariado $(69,8 \%)$ e que ainda não haviam levado seus filhos pequenos ao dentista $(72,6 \%)$. 
Após a análise de regressão logistica, os únicos fatores que permaneceram associados à variável de estudo foram, escolaridade e visita ao dentista.

$E$ interessante ressaltar que encontramos as menores proporções de mães que não haviam recebido orientações, entre aquelas com $3^{\circ}$ grau completo e cujos filhos pequenos já haviam visitado o dentista, 36,4 e 51,\%, respectivamente, 0 que vem a confirmar que o acesso ao dentista, predispõe às mães e crianças a serem orientadas sobre 0 cuidado odontológico. 
QUADRO $\mathrm{N}^{\circ} 9$ - $\operatorname{Total}(\mathrm{n})$, número(n1) e $\%$ de mães segundo orientaçāo sobre cuidados com higiene bucal, características sócio-econômicas e visita ao dentista

\begin{tabular}{|c|c|c|c|c|c|c|}
\hline \multirow[t]{2}{*}{ CARACTERISTICAS } & \multirow{2}{*}{$\underset{n}{\text { TOTAL }}$} & \multicolumn{2}{|c|}{$\mathrm{N} \overline{\mathrm{A} O}$} & \multirow[t]{2}{*}{$x^{2}$} & \multirow[t]{2}{*}{ gl } & \multirow[t]{2}{*}{$\mathrm{p}$} \\
\hline & & $\mathrm{n} 1$ & $\%$ & & & \\
\hline $\begin{array}{l}\text { GRUPO ETÁRIO } \\
15=24 \\
25-29 \\
30-34 \\
35-49\end{array}$ & $\begin{array}{r}111 \\
135 \\
102 \\
51\end{array}$ & $\begin{array}{l}72 \\
79 \\
70 \\
34\end{array}$ & $\begin{array}{l}64,9 \\
58,5 \\
68,6 \\
66,7\end{array}$ & 3,12 & 3 & 0,373 \\
\hline $\begin{array}{l}\text { ESCOLARIDADE } \\
\text { Analf/1 }{ }^{\circ} \text { GRAU INC. } \\
1^{\circ} \text { GRAU COMPLETO } \\
2^{\circ} \text { GRAU COMPLETO } \\
3^{\circ} \text { GRAU COMPLETO }\end{array}$ & $\begin{array}{r}189 \\
73 \\
103 \\
44\end{array}$ & $\begin{array}{r}140 \\
48 \\
56 \\
16\end{array}$ & $\begin{array}{l}74,1 \\
65,8 \\
54,4 \\
36,4\end{array}$ & $26,98^{*}$ & 3 & 0,000 \\
\hline $\begin{array}{l}\text { OCUPAÇÃo } \\
\text { Sim } \\
\text { Nao }\end{array}$ & $\begin{array}{l}161 \\
216\end{array}$ & $\begin{array}{r}93 \\
150\end{array}$ & $\begin{array}{l}57,8 \\
69,4\end{array}$ & $5,00^{*}$ & 1 & 0,025 \\
\hline $\begin{array}{l}\text { RENDA PER CAPITA } \\
\text { Ate } 1 \text { sal.Min. } \\
>1 \text { a } 3 \text { Sal.Min. } \\
>3 \text { a } 10 \text { Sal.Min. }\end{array}$ & $\begin{array}{r}173 \\
153 \\
52\end{array}$ & $\begin{array}{r}121 \\
91 \\
29\end{array}$ & $\begin{array}{l}69,9 \\
59,5 \\
55,8\end{array}$ & 5,51 & 2 & 0,064 \\
\hline $\begin{array}{l}\text { CLASSE SOCIAL } \\
\text { Burguesia } \\
\text { Proletariado } \\
\text { Subproletariado }\end{array}$ & $\begin{array}{r}153 \\
225 \\
34\end{array}$ & $\begin{array}{r}85 \\
157 \\
20\end{array}$ & $\begin{array}{l}55,6 \\
69,8 \\
58,8\end{array}$ & $8,32^{*}$ & 2 & 0,016 \\
\hline $\begin{array}{l}\text { NO. FILHOS }<5 \text { ANOS } \\
1 \\
2-3\end{array}$ & $\begin{array}{l}302 \\
111\end{array}$ & $\begin{array}{r}192 \\
71\end{array}$ & $\begin{array}{l}63,6 \\
64,0\end{array}$ & 0,00 & 1 & 0,966 \\
\hline $\begin{array}{l}\text { VISITA AO DENTISTA } \\
\text { SIM } \\
\text { NÄO }\end{array}$ & $\begin{array}{l}182 \\
212\end{array}$ & $\begin{array}{r}93 \\
154\end{array}$ & $\begin{array}{l}51,1 \\
72,6\end{array}$ & $18,52^{*}$ & 1 & 0,000 \\
\hline TOTAL & 413 & 263 & 63,7 & & & \\
\hline
\end{tabular}

REGRESSÃO LOGÍSTICA - RESULTADOS ANÁLISE DE VARIÂNCIA

\begin{tabular}{lrrl}
\hline Fonte de variação & GL & Qui-Quad. & Prob. \\
\hline INTERCECÇÃO & 1 & 1.30 & 0.2545 \\
ESCOLARIDADE & 3 & 17.95 & $0.0005 *$ \\
OCUPAÇÃO & 1 & 1.38 & 0.2396 \\
CLASSE SOCIAL & 2 & 1.31 & 0.5204 \\
VISITA AO DENTISTA & 1 & 17.03 & $0.0000 *$ \\
RAZÃO DE MAXIMO- & 32 & 32.88 & 0.4235 \\
VEROSSIMILHANÇA & & & \\
\hline
\end{tabular}

(*) Significante ao nível de 5\%. 
Frequência de escovação dos dentes pela criança

A maioria das mães $(72,5 \%)$ considerava importante que as crianças escovassem seus dentes, pelo menos três vezes ao dia (TABELA 39), pensamento que reproduz a fala dos dentistas, a norma odontológica.

TABELA 39 - Opinião das mães sobre o número de vezes que as crianças devem escovar os dentes.

\begin{tabular}{l|rc}
\hline QUANTIDADE & Freq & $\%$ \\
\hline UMA & 9 & $1.6 \%$ \\
DUAS & 89 & $16.1 \%$ \\
TRÊS & 296 & $53.4 \%$ \\
QUATRO & 106 & $19.1 \%$ \\
OUTROS & 54 & $9.7 \%$ \\
\hline Total & 554 & $100.0 \%$ \\
\hline
\end{tabular}

3.3 Práticas e representações da mãe com relação ao uso do flúor

No parecer de CURY'L (1989) "A promoçao de saúde bucal pode ser feita pelo controle da placa dental, da dieta e pelo uso do flúor, e tendo em vista os fatores relacionados com as dificuldade do sucesso absoluto das duas primeiras medidas, o uso do flúor é imprescindivel como meio complementar para o êxito no controle da cárie dentária". 
WALTER e NAKAMA 86 (1992) afirmam que "As caracteristicas dos dentes deciduos mostram que eles são menos calcificados que os permanentes, sendo, portanto, menos resistentes. 0 aumento da resistência se faz predominantemente, pela aplicação diária de flúor em casa, utilizando-se de soluçōes de fluoreto de sódio a $0,02 \%$, por ser eficaz e não determinar overdose, quando usado corretamente. Desta maneira o flúor pode ser usado pela mãe, diariamente, em casa, friccionando os dentes do bebê com um cotonete contendo gotas da solução fluoretada, 4 gotas para cada arco dentário e o excedente de flúor, $60 \%$ do total aplicado, è deglutido pela criança e com isto atingindo a amplitude de ação, que é a interação tópica sistêmica".

Atualmente com relação a ação do flúor no controle do processo de cáries, considera-se importante que o paciente mantenha um regime de alta frequência e baixa concentração de flúor na cavidade bucal, o que pode ser obtido através do uso de dentifrícios fluoretados, de comprimidos de flúor ou do consumo de água fluoretada.

Para grupos de pessoas com médio ou alto risco de cárie, recomenda-se a associação de métodos de baixa concentração de flúor e de alta frequência, com aqueles de alta concentração, como por exemplo, bochechos diários associados a aplicações tópicas profissionais. 
Contato das mães com informações sobre o flúor

Do total das 554 mães, a maioria $(95,1 \%)$ afirmou já haver ouvido falar à respeito do flúor, apontando como principais fontes de informação a escola, o dentista e a televisão (TABELA 40).

TABELA 40 - Distribuição das mães segundo a fonte de informação sobre o flúor.

\begin{tabular}{l|cc}
\hline FONTE & Freq & $\%$ \\
\hline DENTISTA & 135 & $25.6 \%$ \\
TELEVISÃO & 131 & $24.9 \%$ \\
ESCOLA & 158 & $30.0 \%$ \\
OUTROS & 92 & $17.5 \%$ \\
NÃO LEMBRA & 11 & $2.1 \%$ \\
\hline TOTAL & 527 & $100.0 \%$ \\
\hline
\end{tabular}

Entre aquelas que já haviam tido contato com este assunto, 14,8\% não souberam dizer sua utilidade, e a maioria $(79,3 \%)$ conhecia que este serve para proteger os dentes, para evitar as cáries (TABELA 41). 
TABELA 41 - Utilidade do flúor segundo as mães.

\begin{tabular}{l|rc}
\hline UTIIIDADE & Freq & $\%$ \\
\hline Evitar cáries & 210 & $39.8 \%$ \\
Proteção dos dentes & 208 & $39.5 \%$ \\
Limpeza dos dentes & 15 & $2.8 \%$ \\
Outros & 16 & $3.0 \%$ \\
Não sabe & 78 & $14.8 \%$ \\
\hline Total & 527 & $100.0 \%$ \\
\hline
\end{tabular}

Utilização do flúor pela criança

Para nossa surpresa, apesar de a maioria das māes ter demonstrado conhecer os benefícios do flúor, $63,2 \%$ destas afirmaram que seus filhos não o haviam utilizado.

As caracteristicas maternas, associadas à não utilização do flúor pelas crianças, que apresentaram resultados significantes foram: grupo etário, escolaridade, renda "per capita"e visita ao dentista. Sendo que a análise de regressão logistica, permitiu considerar como fatores relacionados a esta prática, apenas, o grupo etário e visita ao dentista (QUADRO 12).

Maiores porcentagens de mães pertencentes aos grupos mais jovens, com $1^{\circ}$ grau incompleto e renda "per capita"até 1 salário mínimo, disseram que seus filhos não utilizaram flúor. 
$\mathrm{Na}$ análise desta variável, fez-se notar a participação do dentista, pois o menor percentual de mães $(38,3 \%)$ que afirmou que os filhos não haviam usado o flúor, foi encontrado entre o grupo de mães que já havia levado um de seus filhos pequenos ao dentista. Mesmo assim, é um percentual considerável, pensando-se que na prática do dentista, com crianças pequenas, está inclusa a aplicação do flúor. 
QUADRO $\mathrm{N}^{\circ} 10$ - Total $(\mathrm{n})$, número(n1) e $\%$ de mães cujos filhos nāo utilizaram fluor segundo caracteristicas sócioeconômicas e visita ao dentista.

\begin{tabular}{|c|c|c|c|c|c|c|}
\hline CARACTERISTICAS & $\begin{array}{c}\text { TOTAL } \\
n\end{array}$ & $\begin{array}{c}\mathrm{NA} O \\
\mathrm{nI}\end{array}$ & $\begin{array}{c}\text { IZARAM } \\
\%\end{array}$ & $x^{2}$ & gl & $\mathrm{p}$ \\
\hline $\begin{array}{l}\text { GRUPO ETARIO } \\
15=24 \\
25=29 \\
30=34 \\
35-49\end{array}$ & $\begin{array}{r}135 \\
172 \\
130 \\
56\end{array}$ & $\begin{array}{r}97 \\
102 \\
73 \\
36\end{array}$ & $\begin{array}{l}71,9 \\
59,3 \\
56,2 \\
64,3\end{array}$ & $8,1^{*}$ & 3 & 0,044 \\
\hline $\begin{array}{l}\text { ESCOLARIDADE } \\
\text { Analf/10 GRAU INC. } \\
1^{\circ} \text { GRAU INCOMPL. } \\
2^{\circ} \text { GRAU INCOMPL. } \\
3^{\circ} \text { GRAU INCOMPL. }\end{array}$ & $\begin{array}{r}225 \\
92 \\
124 \\
52\end{array}$ & $\begin{array}{r}155 \\
62 \\
69 \\
22\end{array}$ & $\begin{array}{l}68,9 \\
67,4 \\
55,6 \\
42,3\end{array}$ & $16,39 *$ & 3 & 0,001 \\
\hline $\begin{array}{l}\text { OCUPAÇĀo } \\
\text { Sim } \\
\text { Nao }\end{array}$ & $\begin{array}{l}186 \\
263\end{array}$ & $\begin{array}{l}106 \\
172\end{array}$ & $\begin{array}{l}57,0 \\
64,4\end{array}$ & 2,92 & 1 & 0,087 \\
\hline $\begin{array}{l}\text { RENDA PER CAPITA } \\
\text { Ate } 1 \text { sal.Min. } \\
>1 \text { a } 3 \text { Sal.Min. } \\
>3 \text { a } 10 \text { Sal.Min. }\end{array}$ & $\begin{array}{r}202 \\
192 \\
58\end{array}$ & $\begin{array}{r}134 \\
119 \\
28\end{array}$ & $\begin{array}{l}66,3 \\
62,0 \\
48,3\end{array}$ & $6,25 *$ & 2 & 0,044 \\
\hline $\begin{array}{l}\text { CLASSE SOCIAL } \\
\text { Burguesia } \\
\text { Proletariado } \\
\text { Subproletariado }\end{array}$ & $\begin{array}{r}181 \\
273 \\
45\end{array}$ & $\begin{array}{r}108 \\
172 \\
33\end{array}$ & $\begin{array}{l}59,7 \\
63,0 \\
73,3\end{array}$ & 2,90 & 2 & 0,235 \\
\hline $\begin{array}{l}\text { No. FILHOS }<5 \text { ANOS } \\
1 \\
2-3\end{array}$ & $\begin{array}{l}385 \\
115\end{array}$ & $\begin{array}{r}249 \\
64\end{array}$ & $\begin{array}{l}64,7 \\
55,7\end{array}$ & 3,08 & 1 & 0,079 \\
\hline $\begin{array}{l}\text { VISITA DENTISTA } \\
\text { SIM } \\
\text { NĀO }\end{array}$ & $\begin{array}{l}193 \\
286\end{array}$ & $\begin{array}{r}74 \\
232\end{array}$ & $\begin{array}{l}38,3 \\
81,1\end{array}$ & $89,55 *$ & 1 & 0,000 \\
\hline TOTAL & 481 & 309 & 63,2 & & & \\
\hline
\end{tabular}

REGRESSÃO LOGÍSTICA - RESULTADOS ANÁLISE DE VARIÂNCIA

\begin{tabular}{lcccc}
\hline Fonte de Variação & GL & Qui-Quad. & Prob. \\
\hline INTERCECÇÃO & 1 & 14.74 & $0.0001 *$ \\
GRUPO ETARIO & 3 & 10.34 & $0.0159 *$ \\
VISITA DENTISTA & 1 & 83.82 & $0.000 *$ \\
RAZÃO DE MAXIMO- & 3 & 6.20 & 0.1025 \\
VEROSSIMILHANÇA & & & \\
\hline
\end{tabular}

(*) - Significante ao nivel de 5\%. 
Conhecimento das mães sobre a fluoretação da ãgua de abastecimento público de Maringá

Como foi comentado na caracterização da área de estudo, a água de consumo público do município de Maringá é fluoretada desde 1967, o que se constitui em importante fator de proteção para a saúde bucal de sua população.

As pesquisas existentes expressam claramente, através de seus resultados, que os benefícios do flúor para a redução da incidência da cárie, quando administrado sistemicamente, através da água de abastecimento público, são da ordem de 40 a $50 \%$, para a dentição decídua e de 50 a $60 \%$, para a permanente.

A fluoretação da água é o mais seguro, efetivo, simples e econômico método de prevenção da cárie dentária e sua adoção em todos as áreas, onde esta doença constitui-se em problema de saúde pública, tem sido uma recomendação, insistentemente, reiterada pelas organizaçōes internacionais e nacionais do setor saúde ( PINTO 57,1989 ).

Neste estudo, encontramos várias contradições na análise desta variável. Uma porcentagem razoável de mães $(41,2 \%)$ sabia que a cidade tem flúor na água, e como vimos, $63,2 \%$ delas também, afirmou que seus filhos nunca haviam tido contato com o flúor, além do que, a maioria disse já ter ouvido falar sobre este halogênio e tinha noção de sua utilidade. Por outro lado, $13 \%$ destas, afirmaram que 0 município não tem água fluoretada e um segmento importante 
delas $(45,4 \%)$ confessou não saber (TABELA 42).

TABELA 42 - Informação das mães sobre a fluoretação da água de abastecimento público de Maringa.

\begin{tabular}{l|rc}
\hline INFORMAÇÃO & Freq & $\%$ \\
\hline Não sabe & 239 & $45.4 \%$ \\
Não & 71 & $13.5 \%$ \\
Sim & 217 & $41.2 \%$ \\
\hline Total & 527 & $100.0 \%$ \\
\hline
\end{tabular}

Entre as mães que disseram saber que a áqua é fluoretada, os motivos apontados para esta medida foram, em primeiro lugar $(51,2 \%)$ a proteção dos dentes, vindo a seguir, $(32,7 \%) \circ$ tratamento da água. Cerca de $16 \%$ destas, confessaram não saber a razão (TABELA 43).

TABELA 43 - Motivo da fluoretação da água de abastecimento público de Maringá.

\begin{tabular}{l|rc}
\hline MoTIVo & Freq & \multicolumn{1}{|c}{} \\
\hline Proteção dos dentes & 111 & $51.2 \%$ \\
Tratamento da água & 71 & $32.7 \%$ \\
Não sabe & 28 & $12.9 \%$ \\
Não respondeu & 7 & $3.2 \%$ \\
\hline Total & 217 & $100.0 \%$ \\
\hline
\end{tabular}


Percebe-se haver muita confusão nas respostas das mães com relação ao flúor, pois quase a metade destas demonstrou não saber o motivo de a água ser fluoretada, sendo que para muitas, o flúor servia para " matar micróbios, vermes e bactérias ....eliminar as impurezas / sujeiras da áqua....evitar doenças " e, anteriormente, cerca de $80 \%$ delas, haviam afirmado que o flúor serve para proteçāo dos dentes / evitar a cárie. Elas deviam relacionar o uso do flúor, somente, a aplicaçōes tópicas profissionais e a bochechos escolares.

\section{4 Procura do dentista para a crianca}

Visita anterior da criança ao dentista

A experiencia dos profissionais que prestam atenção odontológica às crianças pequenas, geralmente especialistas, pois os clínicos gerais sentem enormes dificuldades em trabalhar com esta faixa-etária, é de que os responsáveis pela criança costumam levá-las a seus serviços, somente após os 3 anos de idade, quando já apresenta manifestações da doença.

CROLL $^{20}$ (1984) em um estudo sobre a $1^{\text {al }}$ visita da criança ao consultório, comentou sobre o que chamou de "mito tão persistente, quanto mal orientado ", referindo-se a idade mais seguidamente citada por dentistas e médicos, como a época mais apropriada para a primeira avaliaçāo bucal da 
criança, variando dos 2 aos 3 anos de idade. com muita probidade, argumentou 0 autor, que os odontopediatras consomem, um tempo bastante considerável, restaurando ou extraindo dentes decíduos, afetados por lesões de cáries não detectadas, em crianças mais jovens do que os 3 anos. Segundo ele, ainda que se saiba que a maior parte das doenças bucais são previníveis, dentistas e médicos têm sido muito desatentos para encorajar exames precoces. Pouca informação sobre cuidados bucais, para crianças com menos de 3 anos tem sido, rotineiramente, oferecida nas faculdades de odontologia e cursos de educação continuada, raramente, programam tais orientações.

coerente com as observações de CROLL, está o trabalho desenvolvido por WALKER e $\operatorname{col} .^{83}$ (1984) que ao estudarem as atitudes das mães de crianças em idade préescolar, encontraram que, da população de estudo, apenas $32,4 \%$ das crianças, haviam visitado o dentista na época da pesquisa, das quais, $62 \%$ viram o dentista pela primeira vez aos 3 anos de idade, simplesmente, porque "suas mães consideraram ser esta a melhor idade".

Nas situaçōes onde estão evidentes os sinais e sintomas da cárie, como lesões e cavidades nos dentes, dor, dificuldade na alimentação, irritabilidade $e$ às vezes, febre, há a necessidade de se interpor, prontamente, o tratamento curativo para resolução do problema, o que dependendo da gravidade do quadro, acaba gerando grandes expectativas para criança e sua família, muitas vezes, 
acarretando transtôrnos de ordem psicológica e financeira.

Mesmo quando existe consciência preventiva na familia, que de acordo com PETERSEN ${ }^{63}$ (1990), é mais frequente nas classes mais altas, é somente após os 3 anos de idade da criança que as mães procuram o profissional, na busca de orientações e ações preventivas.

Um achado interessante ao consultarmos a literatura, foi que de fato, além das influências da própria profissão odontológica, há a participação da área médica na criação do mito dos três anos de idade, para primeira visita ao dentista. Entre as orientaçōes recomendadas pelos pediatras às mães de crianças pequenas, com relação à prevenção da saúde bucal, $\operatorname{PAIVA}^{62}$ (1990) deparou-se com o fato de que a maioria deles $(43,9 \%)$, aconselha a primeira visita ao dentista, por volta dos 3 anos de idade.

As atençōes aos pequenos que têm entre 0 e 3 anos de idade, habitualmente, têm tido caráter de urgência. Entre os problemas mais frequentes, encontram-se os traumatismos dentários resultantes de quedas, manifestaçōes agudas da cárie de mamadeira (CORREA ${ }^{3}$, 1992), a erupção de dentes neo e peri-natais e algumas anomalias dentárias.

Do total das 693 crianças de nosso estudo, apenas $35,4 \%$ já havia visitado o dentista, por ocasião da entrevista, sendo que a maioria delas $(61,7 \%)$ nunca havia ido ao dentista (TABELA 44 ). 
TABELA 44 - Distribuição dos filhos segundo visita anterior ao dentista.

\begin{tabular}{l|cc}
\hline VISITA & Freq & $\%$ \\
\hline NĀO & 428 & $61.7 \%$ \\
SIM & 246 & $35.4 \%$ \\
NĀO LEMBRA & 6 & $0.9 \%$ \\
NĀO RESPONDEU & 13 & $2.0 \%$ \\
\hline Total & 693 & $100.0 \%$ \\
\hline
\end{tabular}

A idade das crianças na primeira visita ao dentista, apontada pelas mäes que já as haviam levado, variou entre 0 a 5 anos, havendo maiores porcentagens de crianças nas idades de dois $(11 \%)$ e três $(8,5 \%)$ anos (TABELA 45). Os motivos alegados por elas, para terem procurado o dentista, para seus filhos pequenos, foram: para $28.2 \%$ das crianças, cárie e dor; para 10.2\% delas traumatismos; e para cerca de $50 \%$ destas, motivos preventivos, como avaliação, prevenção e rotina (TABELA 46). Note-se que existia consciência preventiva, para metade daquela parcela de mães, que já haviam levado seus filhos ao dentista. 
TABELA 45 - Idade dos filhos na primeira visita ao dentista.

\begin{tabular}{l|rr}
\hline IDADE & Freq & \multicolumn{1}{c}{$\%$} \\
\hline 1 & 37 & $5.3 \%$ \\
1 & 48 & $6.9 \%$ \\
2 & 76 & $11.0 \%$ \\
3 & 58 & $8.5 \%$ \\
4 & 20 & $2.9 \%$ \\
5 & 7 & $1.0 \%$ \\
Não levou & 428 & $61.7 \%$ \\
Não lembra & 6 & $0.9 \%$ \\
Não respondeu & 13 & $2.0 \%$ \\
\hline Total & 693 & $100.0 \%$ \\
\hline
\end{tabular}

TABELA 46 - Distribuição dos filhos segundo o motivo da primeira visita ao dentista.

\begin{tabular}{|c|c|c|}
\hline MOTIVO & Freq & $\%$ \\
\hline CÁRIE & 51 & $20.5 \%$ \\
\hline DOR & 19 & $7.7 \%$ \\
\hline TRAUMATISMO & 25 & $10.2 \%$ \\
\hline AVALIAR SE ESTAVA NORMAL & 59 & $24.0 \%$ \\
\hline PREVENÇĀO & 50 & $20.3 \%$ \\
\hline ROTINA ESCOLAR & 13 & $5.3 \%$ \\
\hline OUTROS & 29 & $11.8 \%$ \\
\hline Total & 246 & $100.0 \%$ \\
\hline
\end{tabular}


Motivo habitual de procura do dentista para a criança

A maioria (49.6\%) daquelas māes que já havia levado seus filhos pequenos ao dentista, afirmou que o motivo que, geralmente, as faz procurar o dentista para estes é a busca de prevenção, ao passo que $37 \%$ delas, disseram que só procuravam este profissional em situaçōes de necessidade (TABELA 47).

TABELA 47 - Motivo habitual da procura das mães ao dentista para os filhos.

\begin{tabular}{l|rc}
\hline MOTIVO & Freq & $\%$ \\
\hline PREVENÇÃO & 122 & $49.6 \%$ \\
NECESSIDADE & 91 & $37.0 \%$ \\
OUTROS & 7 & $2.8 \%$ \\
NÃO RESPONDEU & 26 & $10.6 \%$ \\
\hline Total & 246 & $100.0 \%$ \\
\hline
\end{tabular}

A análise da associação entre características sócio-econômicas da mãe e o fato de elas buscarem o dentista para seus filhos para prevenção, demonstrou que o único fator associado é o nível de escolaridade destas (QUADRo 11). 
Assim, temos que quanto mais alto o nivel de escolaridade das mães, maior a proporção destas, que demonstrou consciência preventiva. E interessante assinalar que entre as mães mais joveris, com menor grau de escolaridade, que não trabalhavam, com renda até 1 salário minimo "per capita"e pertencentes ao subproletariado, registraram-se as menores porcentagens de māes com consciência preventiva. 
QUADRO $\mathrm{N}^{\circ} 11$ - Total $(n)$, número(n1) e \% de mães segundo motivo habitual para levar filhos ao dentista, características sócio-econômicas e visita ao dentista.

\begin{tabular}{|c|c|c|c|c|c|c|}
\hline CARACTERISTICAS & $\underset{n}{\text { TOTAL }}$ & $\begin{array}{l}\text { PRE } \\
\text { n1 }\end{array}$ & $\begin{array}{r}\text { ÇĀO } \\
\%\end{array}$ & $x^{2}$ & gl & $p$ \\
\hline $\begin{array}{l}\text { GRUPO ETÁRIO } \\
15=24 \\
25-29 \\
30-34 \\
35-49\end{array}$ & $\begin{array}{l}58 \\
85 \\
51 \\
20\end{array}$ & $\begin{array}{l}29 \\
48 \\
29 \\
12\end{array}$ & $\begin{array}{l}50,0 \\
56,5 \\
56,9 \\
60,0\end{array}$ & 0,93 & 3 & 0,818 \\
\hline $\begin{array}{l}\text { ESCOLARIDADE } \\
\text { Analf/1 G GRAU INC. } \\
10 \text { GRAU COMPLETO } \\
2^{\circ} \text { GRAU COMPLETO } \\
3^{\circ} \text { GRAU COMPLETO }\end{array}$ & $\begin{array}{r}255 \\
100 \\
131 \\
54\end{array}$ & $\begin{array}{r}127 \\
58 \\
86 \\
45\end{array}$ & $\begin{array}{l}49,8 \\
58,0 \\
65,6 \\
83,3\end{array}$ & $24,43^{*}$ & 3 & 0,000 \\
\hline $\begin{array}{l}\text { OCUPAÇĀo } \\
\text { Sim } \\
\text { Nao }\end{array}$ & $\begin{array}{r}90 \\
107\end{array}$ & $\begin{array}{l}58 \\
56\end{array}$ & $\begin{array}{l}64,4 \\
52,3\end{array}$ & 2,46 & 1 & 0,117 \\
\hline $\begin{array}{l}\text { RENDA PER CAPITA } \\
\text { Ate } 1 \text { sal.Min. } \\
>1 \text { a } 3 \text { Sal.Min. } \\
>3 \text { a } 10 \text { Sal.Min. }\end{array}$ & $\begin{array}{l}87 \\
83 \\
31\end{array}$ & $\begin{array}{l}42 \\
53 \\
20\end{array}$ & $\begin{array}{l}48,3 \\
63,9 \\
64,5\end{array}$ & 5,01 & 2 & 0,082 \\
\hline $\begin{array}{l}\text { CLASSE SOCIAL } \\
\text { Burguesia } \\
\text { Proletariado } \\
\text { Subproletariado }\end{array}$ & $\begin{array}{r}83 \\
115 \\
20\end{array}$ & $\begin{array}{r}50 \\
64 \\
8\end{array}$ & $\begin{array}{l}60,2 \\
55,7 \\
40,0\end{array}$ & 1,28 & 2 & 0,258 \\
\hline $\begin{array}{l}\text { NO. FILHOS }<5 \text { ANOS } \\
1 \\
2-3\end{array}$ & $\begin{array}{r}155 \\
63\end{array}$ & $\begin{array}{l}91 \\
31\end{array}$ & $\begin{array}{l}58,7 \\
49,2\end{array}$ & 1,28 & 1 & 0,258 \\
\hline $\begin{array}{l}\text { VISITA AO DENTISTA } \\
\text { SIM } \\
\text { NÃO }\end{array}$ & $\begin{array}{r}187 \\
21\end{array}$ & $\begin{array}{r}108 \\
10\end{array}$ & $\begin{array}{l}57,8 \\
47,6\end{array}$ & 0,43 & 1 & 0,511 \\
\hline TOTAL & 218 & 122 & 56,0 & & & \\
\hline
\end{tabular}

(*) Significante ao nivel de $5 \%$ 
4. PARTICIPAÇÃo DA MÃE NO CUIDADO DA SAÚDE BUCAL DA CRIANÇA PEQUENA

A. mãe e o cuidado da criança

A mudança do papel da mulher na sociedade, que vem, gradativamente conquistando as mais variadas posições no mercado de trabalho, pode ser relacionada a vários aspéctos, entre os quais a luta dos movimentos femininos por emancipação da mulher e a questão premente nas familias mais pobres da necessidade de sobrevivência de seus membros.

- fato é que a saída da mulher para trabalhar fora do lar, acaba gerando várias alterações na estrutura e rotina familiares, dentre estas, nos cuidados com os filhos menores De acordo com $\operatorname{GIFFIN}^{27}$ (1991) a separação espacial das atividades de trabalho remunerado afastou o homem do domicilio, ficando a mulher responsabilizada pela totalidade das tarefas domésticas. Apesar disto, quando a familia precisa de renda, ela é lançada na busca de remuneração e assume, normalmente, a dupla jornada de trabalho, remunerado e doméstico. "Nas familias onde a necessidade de renda é mais aguda, nem sempre a necessidade de cuidados aos filhos menores impede a ausência da mãe. Neste caso, a situação vivida expressa um conflito entre as várias necessidades imediatas de sobrevivência da familia". 
Ainda, segundo a autora, "A inserção da mulher pobre no mercado de trabalho no Brasil tem sido, em grande parte, através do serviço doméstico pago. Para as classes empregadoras, a existência da empregada doméstica permite à mulher empregadora trabalhar fora, sem prejudicar os serviços domésticos necessários à família. Sua renda ajuda a manter a qualidade de vida de sua familia, incluindo a capacitação relativamente superior dos filhos como força de trabalho, que é baseada em grande parte no acesso ao ensino pago... Nesta situação, a mulher pobre, na condição de empregada doméstica, contribui para a sobrevivência física de sua familia ao mesmo tempo em que fornece melhores condiçōes para a reprodução da força de trabalho da familia empregadora e sua qualificaça, relativamente superior. A mulher de uma classe, a serviço de uma familia de outra classe, é um dos mecanismos que permite a reprodução de uma estrutura de classe, extremamente desigual".

Através da caracterização de nossos sujeitos de estudo, deparamo-nos com estruturas familiares distintas, no que se refere a inserção da mulher no mercado de trabalho. Assim, em 53\% dos casos, tratava-se do modelo familiar típico, onde as mulheres têm um papel marcadamente doméstico, ficando o domínio do espaço público, assegurado ao homem. Enquanto que, em cerca de $30 \%$ do grupo estudado, a mulher dividia-se entre atividades vinculadas ao trabalho fora do lar e as domésticas. 
Apesar da posição diferenciada entre as mulheres, com relação ao exercicio de atividades remuneradas, a elas era reservada a responsabilidade com os filhos menores, no que diz respeito a alimentação, vestuário, cuidados de saúde e educação.

Assim, tentamos identificar a associação entre as caracteristicas sócio-econômicas da mãe e o cuidado da criança pequena, através das variáveis: local de permanência dos filhos menores durante o dia e pessoa responsável pelo cuidado dos mesmos em casa.

Do total das 693 crianças do estudo, a maioria $(73,6 \%)$ permanecia em casa o dia todo, sendo que as restantes $(26,4 \%)$ ficavam em outros equipamentos sociais, por meio período ou período integral, como berçários, creches ou préescolas. A própria mãe assumia os cuidados de $76,5 \%$ dos pequenos, sendo os demais $23,2 \%$, cuidados por outras pessoas como avós, babá, empregada, vizinhos e irmãos. Vale registrar que duas das crianças pequenas permaneciam sozinhas em casa, durante o dia todo (ANEXO D).

Analisando as características das mães, cujos filhos pequenos permaneciam em casa, observamos associações significantes com escolaridade, ocupação, renda "per capita" e classe social (QUADRO 12). 
E interessante assinalar que entre as mães que possuiam $3^{\circ}$ grau completo e as que trabalhavam, registraram se as menores porcentagens $(57,6$ e $57 \%)$ de filhos que permaneciam em casa. Em concordância com estes dados, entre as mães com maior nível de renda e pertencentes à burguesia, também, houve menor proporção da permanência das crianças em casa $(69,1$ e $72,4 \%)$. 
QUADRO $\mathrm{N}^{\circ} 12$ - Total $(n)$, número(n1) e \% de crianças que ficam em casa segundo caracteristicas sócio-econômicas.

\begin{tabular}{|c|c|c|c|c|c|c|}
\hline CARACTERISTICAS & $\begin{array}{c}\text { TOTAL } \\
n\end{array}$ & $\begin{array}{l}\text { FICAM } \\
\mathrm{n}\end{array}$ & $\begin{array}{c}\text { CASA } \\
\%\end{array}$ & $x^{2}$ & gl & $\mathrm{p}$ \\
\hline $\begin{array}{l}\text { GRUPO ETÁRIO } \\
15=24 \\
25=29 \\
30-34 \\
35-49\end{array}$ & $\begin{array}{r}182 \\
221 \\
159 \\
72\end{array}$ & $\begin{array}{r}153 \\
169 \\
115 \\
55\end{array}$ & $\begin{array}{l}84,1 \\
76,5 \\
72,3 \\
76,4\end{array}$ & 7,14 & 3 & 0,068 \\
\hline $\begin{array}{l}\text { ESCOLARIDADE } \\
\text { Analf/10 GRAU INC. } \\
1^{\circ} \text { GRAU COMPLETO } \\
2^{\circ} \text { GRAU COMPLETO } \\
3^{\circ} \text { GRAU COMPLETO }\end{array}$ & $\begin{array}{r}305 \\
113 \\
145 \\
66\end{array}$ & $\begin{array}{r}240 \\
94 \\
117 \\
38\end{array}$ & $\begin{array}{l}78,7 \\
83,2 \\
80,7 \\
57,6\end{array}$ & $18,33^{*}$ & 3 & 0,000 \\
\hline $\begin{array}{l}\text { OCUPAÇĀO } \\
\text { Sim } \\
\text { Nao }\end{array}$ & $\begin{array}{l}221 \\
359\end{array}$ & $\begin{array}{l}126 \\
324\end{array}$ & $\begin{array}{l}57,0 \\
90,0\end{array}$ & $86,90^{*}$ & 1 & 0,000 \\
\hline $\begin{array}{l}\text { RENDA PER CAPITA } \\
\text { Ate } 1 \text { sal.Min. } \\
>1 \text { a } 3 \text { sal.Min. } \\
>3 \text { a } 10 \text { Sal.Min. }\end{array}$ & $\begin{array}{r}287 \\
226 \\
68\end{array}$ & $\begin{array}{r}238 \\
165 \\
47\end{array}$ & $\begin{array}{l}82,9 \\
73,0 \\
69,1\end{array}$ & $10,19^{*}$ & 2 & 0,006 \\
\hline $\begin{array}{l}\text { CLASSE SOCIAL } \\
\text { Burguesia } \\
\text { Proletariado } \\
\text { Subproletariado }\end{array}$ & $\begin{array}{r}210 \\
364 \\
67\end{array}$ & $\begin{array}{r}150 \\
293 \\
56\end{array}$ & $\begin{array}{l}71,4 \\
80,5 \\
83,6\end{array}$ & $7,77^{*}$ & 2 & 0,021 \\
\hline TOTAL & 642 & 500 & 77,9 & & & \\
\hline
\end{tabular}

REGRESSĀO LOGÍSTICA - RESULTADOS ANÁLISE DE VARIÂNCIA

\begin{tabular}{lccc}
\hline Fonte de Variação & GL & Qui-Quad. & Prob \\
\hline INTERCECÇÃo & 1 & 59.76 & $0.0000 *$ \\
ESCOLARIDADE & 3 & 12.64 & $0.0055^{*}$ \\
OCUPAÇÃO & 1 & 74.70 & $0.000{ }^{*}$ \\
CLASSE SOCIAL & 2 & 1.31 & 0.5206 \\
RAZÃO DE MAXIMO- & 16 & 23.17 & 0.1093 \\
VEROSSIMILHANÇA & & &
\end{tabular}

(*) - Significante ao nível de 5\%. 
Coerentemente com esta análise, verificamos que os maiores percentuais de crianças que eram cuidadas pela própria mãe, encontravam-se entre as mães de baixa escolaridade, que não trabalhavam, com baixo nível de renda e pertencentes ao subproletariado (QUADRO 13).

Adicionalmente, como caracteristica que se apresentou significante na associação com o fato de a própria māe cuidar do filho menor, tivemos o grupo etário da mãe, onde percebemos haver relação inversa entre as maiores proporções de crianças cuidadas pelas mães e a idade destas mães.

Contudo, temos que considerar que após a análise de regressão logística, os únicos fatores que de fato puderam ser relacionados, tanto à permanência da criança em casa, como aos cuidados desta pela própria mãe, foram: escolaridade e ocupação da mãe.

Provavelmente, o fato de as mães com maior nível de instrução, terem mais oportunidades de conseguir empregos regulares, faça com que estas se afastem do lar, durante o dia, deixando as crianças pequenas em outros equipamentos sociais ou destinando os cuidados das mesmas a outras pessoas.

Esta "distância" diária entre as mães e seus filhos pequenos, pelo menos, em termos de promocão a saúde bucal, parece não ser muito prejudicial, pois como visto, foi, justamente, entre as mães que possuiam níveis mais altos de escolaridade, que encontramos maior consciência preventiva e 
maior nivel de conhecimento, sobre aspéctos relacionados ao processo saúde- doença bucal.

o fato de a mãe não trabalhar fora, permanecendo em casa o tempo todo, não garante à criança melhor atenção a sua saúde bucal. Em nosso estudo, no grupo de mães que apresentavam estas caracteristicas, somava-se o fato de a maioria delas possuir baixos nIveis de renda e escolaridade, - que, na prática, traduzia-se em falta de acesso às informaçōes, aos bens de consumo e aos serviços odontológicos. 
QUADRO $\mathrm{N}^{0} 13$ - Total(n), número(nI) e \% de crianças cuidadas diretamente pela mãe segundo variáveis sócio-econômicas.

\begin{tabular}{|c|c|c|c|c|c|}
\hline CARACTERISTICAS & $\underset{n}{\text { TOTAL }}$ & $\begin{array}{l}\mathrm{MA} E \\
\mathrm{n}\end{array}$ & $\begin{array}{r}\text { CUIDA } \\
\frac{\%}{0}\end{array}$ & $x^{2}$ & $\mathrm{p}$ \\
\hline $\begin{array}{l}\text { GRUPO ETÁRIO } \\
15=24 \\
25-29 \\
30-34 \\
35-49\end{array}$ & $\begin{array}{r}191 \\
240 \\
167 \\
75\end{array}$ & $\begin{array}{r}157 \\
185 \\
125 \\
49\end{array}$ & $\begin{array}{l}82,2 \\
77,1 \\
74,9 \\
65,3\end{array}$ & $8,99^{*} 4$ & 0,029 \\
\hline $\begin{array}{l}\text { ESCOLARIDADE } \\
\text { Analf / } 10 \text { GRAU INC. } \\
1^{\circ} \text { GRAU COMPLETO } \\
2^{\circ} \text { GRAU COMPLETO } \\
3^{\circ} \text { GRAU COMPLETO }\end{array}$ & $\begin{array}{r}318 \\
121 \\
156 \\
74\end{array}$ & $\begin{array}{r}260 \\
98 \\
109 \\
46\end{array}$ & $\begin{array}{l}81,8 \\
81,0 \\
69,9 \\
76,7\end{array}$ & $18,62^{*} 3$ & 0,000 \\
\hline $\begin{array}{l}\text { OCUPAÇĀo } \\
\text { Sim } \\
\text { Nāo }\end{array}$ & $\begin{array}{l}246 \\
368\end{array}$ & $\begin{array}{l}130 \\
336\end{array}$ & $\begin{array}{l}52,8 \\
91,3\end{array}$ & $117,11^{*} 1$ & 10,000 \\
\hline $\begin{array}{l}\text { RENDA PER CAPITA } \\
\text { Até } 1 \text { sal.Min. } \\
>1 \text { a } 3 \text { Sal.Min. } \\
>3 \text { a } 10 \text { Sal.Min. }\end{array}$ & $\begin{array}{r}301 \\
244 \\
74\end{array}$ & $\begin{array}{r}248 \\
177 \\
45\end{array}$ & $\begin{array}{l}82,4 \\
72,5 \\
60,8\end{array}$ & $17,67^{*}$ & 20,000 \\
\hline $\begin{array}{l}\text { CLASSE SOCIAL } \\
\text { Burguesia } \\
\text { Proletariado } \\
\text { Subproletariado }\end{array}$ & $\begin{array}{r}232 \\
380 \\
69\end{array}$ & $\begin{array}{r}163 \\
301 \\
58\end{array}$ & $\begin{array}{l}70,3 \\
79,2 \\
84,1\end{array}$ & $8,80^{*} 2$ & 0,012 \\
\hline TOTAL & 642 & 500 & 77,9 & & \\
\hline
\end{tabular}

REGRESSÃO LOGÍSTICA - RESULTADOS ANÁLISE DE VARIÂNCIA

\begin{tabular}{lccc}
\hline Fonte de Variação & GL & Qui-Quad. & Prob. \\
\hline INTERCECÇÃO & 1 & 63.43 & $0.0000 *$ \\
GRUPO ETARIO & 3 & 2.51 & 0.4738 \\
ESCOLARIDADE & 3 & 11.49 & $0.0094 *$ \\
OCUPAÇÃO & 1 & 93.19 & $0.0000 *$ \\
RAZÃO DE MAXIMO- & 23 & 29.38 & 0.1680 \\
VEROSSIMILHANÇA & & & \\
\hline
\end{tabular}

(*) Significante ao nível de 5\%. 


\section{A mãe e a saúde bucal da criança pequena}

Como citado no início deste estudo, vários autores têm enfatizado a importância de se desenvolver açōes educativas, junto a mães de crianças pequenas, objetivando-se alcançar a promoção da saúde bucal da população infantil. Estes, são unânimes em considerar como momento propício para que estas se iniciem, aquele que envolve a gestação e os primeiros anos de vida da criança. (HOLT e col.33,1983; PETERSEN ${ }^{63}, 1990 ;$ STEFFENSEN $^{76}$ ，1990; GRIFFEN e GOEPFERD ${ }^{29}$, 1991; RAYNER 67 , 1992).

Salientando a importância da educação dos pais, durante as consultas pré-natais e logo após o nascimento da criança, SHEIN e col. ${ }^{2}$ (1991), afirmaram que "em nenhum outro período da vida da criança, os pais estão tão abertos às informações em saúde. Encontram-se com alto nível de interesse e motivação, estando cheios de perguntas e ansiosos por respostas e orientações, que possam ajuda-los a assumir a responsabilidade pelos cuidados de saúde de seus bebês.

Esta linha de abordagem, vai de encontro aos estudos que falam da estreita relação que há entre a mãe e a criança pequena. Vários autores, da área de psicóloga, pedagogia, socióloga ressaltam o fato da mãe influenciar a criança, durante 0 seu processo de enculturação e socialização, transmitindo a ela valores e normas de comportamento, com relação a vários aspectos da vida. Está entre eles, o comportamento positivo de saúde bucal, 
traduzido pela valorização da saúde bucal; aquisição de hábitos e práticas apropriados, tanto alimentares como de higiene bucal; uso racional do flúor; e visitas regulares ao dentista. Em oposiçāo a este, a criança pode, tambēm, estar sujeita às influências de um comportamento negativo.

Estas considerações foram confirmadas na pesquisa realizada por $\mathrm{CHEN}^{14}(1986)$, onde, após avaliar o comportamento preventivo de saúde bucal de crianças ( hábito de higiene bucal e visitas regulares ao dentista), o autor encontrou que este, estava fortemente associado ao comportamento correspondente de suas mães.

As influências comportamentais, como, também, já comentado, processam-se de acordo com as posições de classe, definidas na estrutura social. ou seja, temos que levar em consideração que as condições de vida e trabalho, estrutura e funcionamento dos serviços odontológicos, interferem na aquisição de conhecimentos e na adoção de comportamentos maternos e contribuindo para o desenvolvimento de um grupo específico de normas e valores de saúde bucal, que passam a ser transmitidos às crianças pequenas.

Estando de acordo com o pensamento, anteriormente, explicitado, no presente estudo, através da busca empreendida para se tentar captar, conhecer e entender as representações e os comportamentos maternos, com relação ao processo saúdedoença bucal, identificamos uma importante influência de determinantes sociais na definição destes. 
Constatamos que a diferenciada inserção social das mães, expressa em termos da escolaridade, renda "per capita" familiar, ocupação remunerada e situação de classe social, atuou como fator determinante do conhecimento a nivel de senso comum e do tipo de prática dele decorrente, relacionados a alguns aspectos dos cuidados com a saúde bucal.

Por outro lado, verificamos que, independentemente, da posição ocupada na estrututura social, alguns conhecimentos e práticas relacionados ao processo saúdedoença bucal infantil, eram compartilhados por todas as mães do estudo. Muitos destes, estavam em desacordo com o conhecimento científico expresso na literatura odontológica, e, podiam, até, constituir-se em fatores que colocavam em risco a saúde bucal das crianças pequenas. No nosso entender - precário conhecimento materno e as práticas negativas a ele associadas, além das influências culturais, traduziam o escasso acesso a informação sobre a saúde bucal dos bebês e pré-escolares, que a totalidade das mães tem.

Consideramos, ainda, que contribuiu para o fato de as mães terem expressado total desconhecimento sobre algumas questões ou terem demonstrado um saber ingênuo, traduzido em práticas prejudiciais à saúde bucal de seus filhos, o descaso que vem sendo observado em nosso país, no estabelecimento das políticas de saúde bucal, com relação à promoçāo da saúde bucal das crianças pequenas e o tipo de formação que os profissionais da área vêm recebendo. 
Observamos a pouca valorização dada pelas mães aos dentes permanentes, sendo esta mais acentuada em relação aos decIduos. Em suas representaçōes, um grupo de mães deixou transparecer a pouca preocupação com estes dentes, apoiando-se em sua transitoriedade (Tabelas 17 e 18).

Uma peculiaridade observada quando se enfoca a saúde bucal da criança pequena é , justamente, a existência, em certos grupos familiares, de uma mentalidade errônea sobre a dentição decídua, também conhecida como de leite, primária, temporária, provisória ou caduca. Estas pessoas consideram que por ser naturalmente "substituivel", não inspira cuidados, direcionando suas preocupações para a dentição permanente, a "definitiva ", que tem inicio, por volta dos 6 anos de idade (Tabela 18).

A pouca valorização dada à dentição decídua por alguns grupos pode, também, ser notada através dos resultados do estudo de WALKER e col.83 (1984), onde $89 \%$ das mães, responderam que não sentiam que suas crianças, em idade préescolar tivessem problemas ou necessidades odontológicas e apenas $65 \%$ das familias, neste grupo, acreditavam que os dentes dos bebês tinham valor de restauração.

No presente estudo, a falta de conhecimento e a pouca preocupação com os dentes deciduos, estavam permeadas pela posição de classe e pelo nivel educacional das mães. Contudo, o desconhecimento sobre os dentes, estava mais fortemente associado ao fato de que, por ocasião da entrevista, a maioria das mães não havia, ainda, procurado o 
dentista para seus filhos menores. E, sendo este profissional, o principal agente difusor do conhecimento técnico-científico odontológico, a dificuldade ou falta de acesso ao atendimento, naturalmente se impuseram como barreiras à transmissão e a assimilaçāo de informações sobre questões relativas à saúde bucal.

Sabemos que, em nosso país, as mães que integram as camadas populares (a maioria), não têm acesso aos consultórios odontológicos particulares e que estas, limitam suas idas ao dentista a tratamentos eventuais ou de urgência, onde se deparam com o modelo de prática hegemônico, em que há pouco espaço para sua participação, havendo predomínio do monólogo do dentista, que fala a educandos considerados como "gananciosos", conforme explicitado no item 3 da introdução, expressando uma forte discriminação de classe.

De fato, em nosso estudo, pudemos perceber que as informaçōes sobre a cárie dentária foram compartilhadas por profissionais e mães, em função da posição de classe delas, ou seja, as mães, com inserção mais elevada na estrutura social, o que, consequentemente lhes possibilitava possuir os níveis mais altos de renda e escolaridade e a ter garantido seu acesso aos consultórios particulares, demonstraram ter tido contato com os conhecimentos técnico-científicos, ainda, que expressando-os, muitas vezes, de forma fragmentada. Em contrapartida, diante das políticas odontológicas vigentes e do perfil do profissional formado, aquelas, que pertenciam às classes proletárias, com poucos anos de estudo e com baixas 
rendas familiares, que, no presente estudo, eram a maioria, deixaram transparecer através de suas respostas, as limitaçōes a que eram submetidas, tanto no acesso aos serviços, como às informações sobre como prevenir e controlar esta doença.

- Quadro 2 ilustra bem esta situação, no qual 50\% das mães que já haviam procurado o dentista para seus filhos pequenos (lembre-se que da totalidade de mães, a minoria havia procurado o dentista, por ocasião da entrevista), afirmou não ter recebido qualquer explicação sobre a cárie dentária. Estes dados demonstram que a filosofia hegemômica de ensino odontológico, traduzida por curar a doença, sem a preocupação com a promoção da saúde do indivíduo, considerado nas suas características bio-psico-sociais, como alguém que faz parte de uma família e está inserida em uma determinada sociedade, parece estar repercutindo nos conhecimentos, atitudes e comportamentos familiares com relação aos cuidados com relação à saúde bucal infantil.

Apesar das parcelas mais expressivas das mães, encontrarem-se à margem do atendimento e do conhecimento técnico-científico odontológico, por suas próprias condições de classe, esperavamos poder captar o "saber popular" construido por todas elas, a cerca do conceito de cárie, suas causas e possibilidades de prevenção. Surpreendemo-nos com o fato de, aproximadamente $40 \%$ destas, não terem conseguido expressar qualquer conceito sobre a doença e aquelas que a conceituaram, ofizeram de maneira bastante imprecisa (Tabela 
26).

Podemos dizer que, quase a totalidade das mães não tinha uma idéia clara sobre o que é a cárie dentária. Tentando explicar esta doença, elas se referiam aos seus sinais, a comportamentos inadequados, mais especificamente, os de higiene bucal e a presença de bactérias, demonstrando assim, reter apenas fragmentos do discurso cientifico, sem contudo, compreendê-lo.

Percebemos, também, que as mães não tinham visão da multicausalidade da cárie. Elas identificavam, apenas, fatores isolados, como a falta de higiene ou o consumo de doces ou a presença de bactérias, como responsáveis pelo aparecimento da doença. Um pequeno percentual conseguia associar doces e falta de higiene (Tabela 25).

$\hat{E}$ interessante ressaltarmos, que a maioria das mães entendia que a principal causa da cárie é a falta de higiene e, talvez, justamente por isso, as maiores proporçōes destas, tenham indicado a escovação dos dentes como forma de prevenção da doença (Tabela 26).

Consideramos que, a eleição da falta de higiene, como principal causa da cárie e a escovação dentária, como melhor maneira de impedi-la, deva receber fortes influências 
da "indústria cultural"*, com a midia incentivando 0 consumo de dentifricios e escovas de dente.

A valorização, por parte das mães, da higiene bucal como medida preventiva da cárie, parece não ter surtido o efeito esperado nas práticas maternas com relação aos cuidados da saúde bucal das crianças pequenas. Os procedimentos de higiene da boca do bebê, não foram realizados em mais da metade das crianças do estudo, isto estando, fortemente, associado a falta de acesso ao dentista e aos baixos níveis de instrução da maioria das mães do estudo (Quadro 10).

A indústria cultural, ao mesmo tempo que promove a difusão de hábitos higiênicos, como medida preventiva da cárie, promove o consumo de alimentos cariogênicos, além do que, reforça o hábito de " beliscar " entre as refeições.

Nas representações da maioria das mães, pudemos perceber que estas não estabeleciam qualquer relação entre fatores alimentares e o desencadeamento da cárie, o que ficou evidente através de suas práticas, pois, mais da metade delas possuia o hábito de "beliscar" entre as refeiçōes principais; seus filhos pequenos tinham o hábito de mamadeira noturna; quase que a totalidade delas acrescentava alguma

* o termo "indústria cultural" é uma criaçlo de Adorno e Horkheimer em seu livro "Dialética do iluminismo", traduçło brasileira publicada por Lima, Lins Costa org. "Teoria da cultura de massa, Rio, SAGA, 1969 p. 157-202. Segundo Adorno "a indústria cultural é a integraçlo deliberada, a partir do alto, de seus consumidores". Expressa "o caráter repressivo da sociedade que se auto-aliena", que padroniza os consumidores, suas técnicas duplicam os objetos empíricos, o que torna mais fácil fazer crer, que o mundo real "é o simples prolongamento, daquilo que acaba de ver no cinema". 
substância açucarada à mamadeira (quadro 8); e quase que a totalidade das crianças, por sua vez, também, apresentava o hábito de comer frequentemente, entre as refeiçōes, sendo que ingeriam nestes momentos, principalmente, alimentos cariogênicos (Quadro 9). Mais de 50\% das mães, consideravam este hábito saudável, sendo elas próprias, as principais responsáveis pela oferta destes alimentos. Com certeza, o pouco conhecimento demonstrado pelas mães sobre hábitos alimentares mais saudáveis, sob o ponto de vista odontológico, e, talvez, um importante componente cultural com relação a preferência destas pelos alimentos doces, configuravam-se em fatores de risco à cárie, tanto para as crianças, como para as próprias māes.

com relação ao uso do flúor, a maioria das mães $(80 \%)$, conhecia a sua importância para proteção dos dentes, evitando a cárie (Quadro 12). Apesar disto, elas demonstraram desconhecer os métodos utilizados para se obter os benefícios deste elemento. Mais da metade destas, afirmou que seus filhos menores não haviam, ainda, utilizado o flúor, por ocasiāo da entrevista, simplesmente, desconhecendo ou desconsiderando o fato de que a água de abastecimento público do municipio é fluoretada e que os dentifrícios contêm flúor (Tabela 42). Elas, provavelmente, deviam relacionar o uso do flúor, somente, a aplicações tópicas profissionais e a bochechos escolares, ignorando que seus filhos e elas próprias já estavam recebendo, de forma passiva, sua proteção. 
Como já detalhado anteriormente, por ocasião da entrevista, grande parte das mães, não havia ainda se preocupado em levar seus filhos pequenos ao dentista e, das que o haviam levado, a metade o fez por razōes preventivas. A consciência preventiva das mães estava, diretamente, associada aos níveis de escolaridade destas (Tabelas $45,46 \mathrm{e}$ 47).

E interessante ressaltarmos, que dentre as variáveis sociais estudadas, a que esteve presente, permeando todas as representações e práticas maternas foi o nível de escolaridade. Assim, o conhecimento sobre a cárie, suas causas e formas de prevenção, bem como as práticas visando a prevenção desta doença em seus filhos menores, foram observados entre as mães que possuiam os níveis mais altos de escolaridade, vale dizer, que estas eram a minoria. A maioria das mães de nosso estudo demonstraram possuir pouco conhecimento sobre as questōes relativas a saúde bucal própria e a de seus filhos, o que foi refletido em suas práticas.

Para finalizar, esperamos que este diagnóstico sobre as representações e práticas maternas, com relação à saúde bucal infantil, possa contribuir para chamar atenção para a criança pequena como sujeito prioritário das políticas odontológicas no país. Em relação ao Município de Maringá, que os dados obtidos possam servir imediatamente para 0 planejamento de açōes educativas a serem implementadas pelo setor saúde. Em relação ao ensino de odontopediatria e 
Pediatria Preventiva, os dados poderão imediatamente ficar disponiveis para serem analisados pelos alunos. Sua problematização deverá servir como instrumento para formação de sua consciência crstica: 
V - CONCLUSÕES 
No presente estudo, o conhecimento odontológico das mães, em nível de senso comum, acerca do processo saúdedoença bucal, foi buscado, fundamentalmente, em suas representaçōes e práticas relacionadas à cárie dentária.

A análise das respostas obtidas junto às entrevistadas, permitiu-nos formular as conclusões que se seguem.

Em relação ao objetivo 1:

- Foram evidentes as desigualdades sociais no acesso às informações odontolólogicas. Mães pertencentes à classe proletária e possuindo menor nível de escolaridade não receberam explicações sobre a cárie dentária, bem como saber os cuidados de higiene bucal de seus filhos pequenos. Vale dizer, que estas eram a maioria. Em contrapartida, aquelas inseridas na burguesia e que apresentavam curso superior, foram orientadas.

- O fato de a mãe já haver procurado o dentista para seus filhos menores não the garantia 0 acesso às informações técnico-científicas. Permanecendo a relação profissionalpaciente havia uma forte discriminação de classe, em que conhecimentos, que possibilitassem a participação efetiva da mãe nos cuidados da saúde bucal de seus filhos, eram transmitidos às mães situadas na mesma posição de classe e que tinham o mesmo nivel de instrução do profissional. 
Em relação ao objetivo 2:

- Quase a totalidade das mães não conseguiu formular um conceito claro sobre o que é a cárie dentária. Explicaram esta doença, através de seus sinais, de comportamentos pessoais inapropriados, mais especificamente os de higiene bucal e pouca delas, fizeram referências a presença de bactérias, demonstrando, assim, reter apenas fragmentos do conhecimento transmitido pelos profissionais, divulgado nas escolas ou veiculado nos meios de comunicaçāo de massa.

- A maioria das mães apresentava uma visão unicausal da cárie. Para elas, esta doença era consequente, principalmente, da falta de higiene $(42,6 \%)$ ou do consumo de doces $(20,6 \%)$. Uma pequena parcela associou falta de higiene e consumo de doces.

Esta visão fez com que elas valorizassem a escovação dentária, como principal medida de prevenção da cárie, dando pouca importância ou desconhecendo o importante papel dos fatores alimentares na definição do risco que as pessoas têm de desenvolver esta doença.

- Houve contradição entre a valorização da higiene bucal como medida preventiva e a prática da maioria das mães, pois os procedimentos de higiene da boca do bebê não tem sido por elas realizados. Este fato mostrou-se, fortemente associado do ponto de vista estatístico à falta de acesso ao dentista e aos seus baixos níveis de instruçāo. 
- Ainda, com referência às formas de prevenção da cárie, um grupo de mães reportou-se, exclusivamente, à procura ao dentista. Transferindo, assim, toda a responsabilidade sobre os cuidados de saúde bucal a este profissional, isentando-se de sua própria participação. outro grupo, reproduziu as recomendaçōes do setor, quais sejam, uso de flúor, higiene bucal correta, dieta com restriçāo de açúcar e visitas regulares ao dentista. Lembre-se que este representava a minoria das mães.

- Houve contradições, também, com relação ao conhecimento sobre o flúor. APesar de a maioria das mães, ter relacionado a ação do flúor à prevenção da cárie, elas não souberam relacionar esta ação à fluoretação da água de abastecimento público. Desconheciam que elas e suas familias, embora, passivamente, estavam recebendo os benefícios deste elemento.

Em relação ao objetivo 3:

- A não associação entre fatores alimentares e a cárie dentária, por parte das mães, independentemente de suas inserçōes sociais, pôde ser notada através de seus hábitos e práticas alimentares, próprios e de seus filhos. 
Mais da metade delas, possuia o habito de comer, frequentemente, entre as refeiçōes principais, o que era reproduzido pela maioria de seus filhos. Estes ingeriam nestes momentos, principalmente, alimentos cariogênicos, sendo suas mães, as principais responsáveis pela oferta destes alimentos.

A maioria das crianças pequenas, apresentava ou havia apresentado o hábito de mamadeira noturna, sendo que a totalidade de suas mães acrescentava alguma substância açucarada ao leite.

- A maioria das mães só procurava ajuda profissional, quando algum problema bucal chegava a incomodá-las e por ocasião da coleta de dados, grande parte delas não havia, ainda, preocupado-se em levar seus filhos pequenos ao dentista. Entre as mães que já os haviam levado, 50\% das razões foram preventivas. A consciência preventiva estava, diretamente, associada aos níveis de escolaridade das mães.

- As atividades regulares de trabalho das mães fora do lar, não necessariamente, implicaram em desatenção à saúde bucal de seus filhos menores. Pelo contrário, os melhores niveis de escolaridade e de renda das mães que se encontravam inseridas no mercado formal de trabalho $(37,4 \%$ delas), possibilitavam-lhes, também, o acesso aos bens de consumo e serviços odontológicos e, nestes, às informaçōes sobre as práticas preventivas próprias e aquelas relacionadas aos cuidados bucais das crianças. 
Em geral:

- As práticas e representaçōes da maioria das mães sobre a saúde bucal das crianças pequenas, expressam sua exlusão, quase que total, das informaçōes cientificas sobre a gestão.

- Levando-se em consideração que os indivíduos, nos seus primeiros anos de vida, são fortemente influenciados pelos valores, representaçōes e práticas maternas, e, que os acabam reproduzindo, a análise global dos resultados do presente estudo, permite-nos inferir que, um percentual significativo de bebês e pré-escolares, do município de Maringá, apresenta grande risco de ter a saúde bucal comprometida, pelo desenvolvimento de cárie.

o tipo e a qualidade de participação de suas mães nos cuidados odontológicos são os grandes responsáveis por isso, que, por sua vez são consequentes da ideologia dos profissionais do setor e das políticas de saúde bucal desfocalizadas desta faixa de idade tão importante e de modo geral excludente em relação as classes populares. 
VI - REFERÊNCIAS BIBLIOGRÁFICAS 
1. ABRAMO, P. Pesquisa em ciências sociais. In: Hirano, S. Pesquisa social: projeto e planejamento. São Paulo, T.A. Queiroz, 1979. cap. 2, p. 21-88.

2. ANDRADE, M.T.D. Regras de citação em textos de saúde pública. São Paulo. Faculdade de Saúde Pública da USP, 1988. (Orientação Bibliográfica, 3).

3. APCD. Bebês e gestantes vão mais ao dentista. $15^{\circ}$ Congresso Paulista de Odontologia em Notícias, São Paulo, 26 jan. 1992. p.l.

4. ARIES, P. História social da criança e da família. Rio de Janeiro, Guanabara, 1986.

5. BARROSO, C. Mulher e politicas públicas. Rio de Janeiro, IBAM/UNICEF, 1991. cap. 10, p. 135-47: A mulher, o planejamento familiar e a administração municipal.

6. BOLTANSKI, L. As classes sociais e o corpo. $3^{\text {a }}$ ed. Rio de Janeiro. Ediçōes Graal, 1989.

7. Botazzo, C. A saúde bucal nas práticas coletivas de saúde.[Resumo] Apresentado no $2^{\circ}$ Congresso de Saúde Coletiva e $3^{\circ}$ Congresso Paulista de Saúde Pública, são Paulo, 1989 .

8. BRASIL. Ministério da Saúde. Secretaria Nacional de Programas Especiais de Saúde. Divisão Nacional de Saúde Bucal. Levantamento epidemiológico em saúde bucal, zona urbana, 1986. Brasilia, CD-MS, 1988. 
9. BRASIL. Ministério da Saúde. Secretaria Nacional de Programas Especiais de Saúde. Divisão Nacional de Saúde Bucal. Perfil da odontologia brasileira. Brasilia, 1988. (DNSB - Doc. Téc. 01/88).

10. BREILH, J. \& GRANDA, E. Saúde na sociedade. São Paulo, Instituto de Saúde - ABRASCO, 1986.

11. BRONFMAN, M. \& TUIRAN, R. La desigualdad ante la muerte: clases sociales $y$ mortalidad en la ninez. cuad. Med soc., 29/30 (1): 53-75, 1984.

12. BURALLI, K.o. Aleitamento materno: o social desfigurado. São Paulo, 1986 [Tese de Doutorado - Faculdade de Saúde Pública da USP].

13. CAMPESTRINI, S. Alojamento conjunto e incentivo à amamentação. Curitiba, EDUCA, 1983.

14. CHEN, M. Children's preventive dental behavior in relation to their mothers' socioeconomic status, health beliefs and dental behaviors. J. Dent. Child., 56: $105-9,1986$.

15. CONFERÊNCIA NACIONAL DE SAÚdE BUCAL, $1^{\mathrm{a}}$, Brasilita, DF, 1986. Relatório final. Brasília, Centro de Documentação do Ministério da Saúde, 1986.

16. CORDÓN, J. \& GARRAFA, V. Prevenção versus preventivismo. Divulgação em saúde para debate, 6: 10-8, 1991. 17. costA, N.R. Estado, educação e saúde: a higiene da vida cotidiana. Cad. CeDEs, 4: 5-27, 1987. 
18. CostA, J.F. ordem médica e norma familiar. $3^{a}$ ed., Rio de Janeiro, Graal, 1989.

19. COSTA NETO, P.L.O. Estatistica. São Paulo, Edgard Blucher, 1977. p. 135-40.

20. CROLL, T.P. A child's first visit: a protocol. Qintessence Int. 6: 1-13, 1984.

21. CURY, J. Uso do flúor. In: Baratieri, L.N. Dentistica: procedimentos preventivos e restauradores. São Paulo, Livraria Editora Santos, 1990, Cap. 2, p.43-67.

22. DEMO, P. Metodologia cientifica em ciências sociais. São Paulo, Atlas, 1985.

23. DonnAngelo, M.C.F. A pesquisa na área da saúde coletiva no Brasil: a década de 70. In: ABRASCO. Ensino da Saúde Pública, Medicina Preventiva e Social no Brasil. Rio de Janeiro, 1983.

24. FRAZIER, J.P. Research on oral health education and promotion and social epidemiology. J. Public Health Dent., 52:18-2, 1992 .

25. FREIRE, P. Educação e mudança. Rio de Janeiro, Paz e Terra, 1979 .

26. FUKADA, $H$. et al. Incidence of the primary dental caries of infants in Japan. J. Nikon Univ. Sch. Dent., $17(3): 54-65,1975$.

27. GIFFIN, K. Mulher e politicas públicas. Rio de Janeiro, IBAM/UNICEF, 1991. cap. 13, p. 169-86: A mulher, a cidade e os programas sociais. 
28. GOHN, M.G.M.

A pesquisa nas ciências sociais: consideraçōes metodológicas. Cad. CEDEs, 12: 3-14, 1985 .

29. GRIFFEN, A.L. \& GOEPFERD, S.J. Preventive oral health care for the Infant, child, and adolescent. Pediatr. clin. North Am., 38: 1209-26, 1991.

30. GRYTTEN, J. Accessibility of Norwegian dental services according to family income from 1977 to 1989. Community Dent. Oral Epidemiol., 20: 1-5, 1992.

31. HEATON, K.W. Açúcares nas doenças humanas. Bibl. Cient. ABOPREV, 2: 2-7, 1991.

32. HOLT, R.D. et al. Dental health education through home visits to mothers with young children. Community Dent. Oral Epidemiol., 11: 98-101, 1983.

33. HOLT, R.D. et al Effects of dental health education for mothers with young children in London. Community Dent. Oral Epidemiol., 13: 148-51, 1985.

34. HUNT, R.J. Behavioral and sociodemographic risk factors for caries. IN: Bader, J.D. Risk assessment in dentistry. North Carolina, Chapel Hill, 1990.

35. KAY, E.G. \& BLINKHORN, A. A study of mothers! attitudes towards the prevention of caries with particular reference to fluoridation and vaccination. Community Dent. Health, 6: 357-63, 1989.

36. KINNBY, C.G. et al. Evaluation of information on dental health care at child health centers. Acta odontol. Scand., 49: 289-5, 1991. 
37. KWON, H.S. \& GUEDES-PINTO, A.C. Higiene buco dental em crianças. In: Guedes-Pinto, A.C. Odontopediatria. São Paulo, Santos, 1988, cap. 28, p.583-613.

38. L'ABBATE, $S$. et al. A educação em saúde como um exercício de cidadania. Saúde em Debate, 37: 81-5, 1992 .

39. LANDMAN, J. Evitando a saúde \& promovendo a doença. $4^{\text {a }}$ ed. Rio de Janeiro, Guanabara Dois, 1986.

40. LAURELl, A.C. Prólogo do livro. In: Breilh, J. Epidemiologia, economia, medicina y politica. Republica Dominicana, Min. Salud y Bienestar Soc., 1983 .

41. LOBO, E. A pesquisa e a metodologia da educação para a saúde. Cad. CEDES, 4: 554-61, 1987.

42. LOMBARDI, $c$. et al. Operacionalização do conceito de classe social em estudos epidemiológicos. Rev. Saūde Públ, 22:253-65, 1986.

43. MACIEL, S.M. Estudo clínico da ação do diaminofluoreto de prata à $10 \%$ sobre superficies oclusais de molares decíduos. São Paulo, 1988, 200 p. [Dissertação de Mestrado - Faculdade de Odontologia da USP ] .

44. MARINGÁ. Prefeitura Municipal. Proposta de municipalização dos serviços de saúde. Maringá, 1987. 45. MARINGÁ. Secretaria Municipal de Saúde. Plano plurianual do Municipio de Maringá 1990/1992. Maringá, 1991. 
46. MARINGÁ. Secretaria Municipal de Saúde. Pró-saúde: Programa Regional de saúde e Programas de Promoção a Saúde Metropolitana 1991/1995. Maringá, 1991.

47. MARINGĀ. Secretaria Municipal de Saúde. Seção de Saúde Bucal. I Ievantamento epidemiológico em odontologia do município de Maringá - 1991. Maringá, 1992.

48. MARTINIC, $S$. \& SAINZ, H. Investigacion participativa $Y$ cultura popular: una experiencia en curso. Cad. CEDES, $2: 15-31,1985$.

49. MCCAUL, K.D. et al. The problem of creating habitis: establishing health - protective dental behaviors. Health Psychol, 11: 101-10, 1992.

50. MCDONALD, R.E. Odontopediatria. $2^{a}$ ed. Rio de Janeiro, Guanabara Koogan, 1977.

51. MELLo, J.A.C. Educação sanitária: uma visão crítica. Cad. CEDES, 4: 28-43, 1987 .

52. MENENDEZ, O.R. Iatrogenia por fazer e por não fazer. In: Jornada Brasileira de Estomatologia, $5^{\mathrm{a}}$, Curitiba, 1979. Anais. Curitiba.

53. MERHY, E. Saúde e movimento popular: o relato de uma experiência. Cad. CEDEs, 4: 44-53, 1987.

54. NARVAI, P.C. Prática odontológica no Brasil: propostas e ações no período 1952-92. São Paulo, 1993. [Dissertação de Mestrado - Faculdade de Saúde Pública da USP] 
55. NEUMANN, E. A criança: estrutura e dinâmica da personalidade em desenvolvimento desde o inicio de sua formação. São Paulo, Cultrix, 1991.

56. NEWBRUN, E. Cardiologia, São Paulo, Livraria Editora Santos, 1988 .

57. NORONHA, D.P. \& ANDRADE, M.T.D: Normas de refeências bibliográficas aplicadas à saúde pública. $2^{\text {a }}$ ed. são Paulo. Faculdade de Saúde pública da USP, 1990 (Orientação Bibliográfica, 2).

58. NUNES, E.D. org., As ciências sociais em saúde na América Latina: tendências e perspectivas. Brasilia, Organização Panamericana da Saúde, 1985.

59. NUNES, E.D. As ciências sociais em saúde no Brasil e na América Latina. In: Cohn, A. et al. Pesquisa social em saúde, São Paulo, Cortez, 1992. p. 25-44.

60. OLIVEIRA, D.C. O desenvolvimento infantil e suas representaçōes: dimensōes do saber técnicoprofissional e do senso comum. São Paulo, 1990. 172 p. [Dissertação de mestrado - Faculdade de saúde Pública da USP] .

61. OSHIRO, J.H. Evolução para a saúde nas instituições de saúde pública. São Paulo, 1988 [Dissertação de mestrado - PUCC/São Paulo].

62. PAIVA, M.S. O pediatra e a saúde oral da criança. RGo, $38(2): 96-100,1990$. 
63. PETERSEN, P.E. Social inequalites in dental health towards a theoretical explanation. community Dent. oral Epidemiol., 18: 153-8, 1990.

64. PETERSEN, P.E. Oral health behavior of 6 year-old danish children. Acta Odontol. Scand., 50: 57-64, 1992 .

65. PINTO, V.G. Saúde bucal: panorama internacional. Brasilia, Centro de Documentação do Ministério da Saúde, 1990 .

66. RAYMER, R.N. \& GIFT, H.C. Contributing factors to maternal and child oral health. J. Public. Health Dent., 50: 370-8, 1991, Special Issue.

67. RAYNER, J.A. A dental health education programme, including home visits, for nursery school children. Br. Dent. J., 172: 57-62, 1992.

68. ROSNER, B.A. Fundamentals of biostatistics. PWS-KENT Publishing Comp. 1990. p. 432-6.

69. ROSSOW, I. \& HOLST, D. Legislation and reality in public dental services in Norway: dental health services for children and adolescents in 1975 and 1985. J. Public Health Dent., 51: 152-7, 1991.

70. RUGG-GUNN, A.J. Dieta e cárie dentária: a importÂncia dos testes de cariogenicidade. Bibl. cient. ABOPREV, $2: 8-10,1991$.

71. S.A.S. INSTITUTE Inc. SAS/STAT Gide for Personal Computers, Version 6 Edition Cary, NC, USA, 1987. p. $189-280$. 
72. SHEIN, B. et al. Self reported compliance and the effectiveness of prenatal dental education. J. clin. Ped. Dent. 15: 102-8, 1991.

73. SOARES, E.L. Educação em saúde bucal nas escolas estaduais do $1^{\circ}$ grau do município de São Paulo. São Paulo, 1988. 98 p. [Tese de Doutorado - Faculdade de Saúde Pública da USP].

74. SOGAARD, A.J. et al. Recent changes in health related dental behaviors in Norway. Community Dent. Oral Epidemiol., 19: 241-5, 1991.

75. SOUZA, R.K.T. Mortalidade infantil e sub-registro de nascidos vivos no município de Maringá-PR, em 1989. São Paulo, 1992. [Dissertação de Mestrado - Faculdade de Saúde Pública da USP].

76. STEFFENSEN, J.E.M. Literature and concept review: issues in maternal and child oral health. J. public Health Dent., 50:358-69, 1990, special issues.

77. STROMBECK, R. The swedish study circle - possibilities for application to health education in the United States. Health Educ. Res, 6: 7-17, 1991.

78. TAVARES, M.F.I. A construção social do saber pediátrico ao nível da graduação: contribuição ao seu estudo. Rio de Janeiro, 1990. [Dissertação de mestrado - Instituto Fernandez Figueira da Fundação oswaldo Cruz].

79. THYLSTRUP, A. \& FEJERKOV, O. Tratado de cariologia. Rio de Janeiro, Ed. Cultura Médica, 1988. 
80. VACINAÇÃo superou $90 \%$ do objetivo, diz Alceni. Folha de S. Paulo, São Paulo, 16 jun. 1991. p. 4-7.

81. VICTORA, C.G. et al. Epidemiologia da desigualdade. $2^{a}$. ed., São Paulo, HUCITEC, 1989.

82. VOLKER, J.F. \& RUSSEL, D.L. Epidemiologia de las caries dentales. In: Finn, S.B. Odontologia pediátrica. $4^{\text {a }}$ ed. México, Interamericana, 1976. cap. 20, p. 396-412.

83. WALKER, J.D. et al. Parental attitudes and dental disease in preschool children In: Iowa. J. Dent. child., 51: 141-5, 1984.

84. WALTER, L.R.F. et al Cárie em crianças de 0 a 30 meses de idade e sua relação com hábitos alimentares. Enc. Bras. Odont., 12 : $129-36,1987$.

85. WALTER, L.R.F. et al "Odontologia no primeiro ano de vida: relatório 1. Londrina, 1985 (Convênio FINEPUniversidade Estadual de Londrina).

86. WALTER, L.R.F. \& NAKAMA, L. Atualização na clínica Odontológica: o dia-a-dia do clínico geral. São Paulo, Artes Médicas, 1992. Cap. 18, p. 251-8: Paciente de Alto Indice de cárie versus paciente de alto risco: qual a conduta?

87. WEINTRAUB, J.A. \& BURT, B.A. Oral health status in the United states: tooth loss and edentulism. J. Dent. Educ., 49 : 368-78, 1985.

88. WESTPHAL, M.F. Participação da mãe no cuidado da criança com asma brônquica. São Paulo, 1982. [Tese de Doutorado - Faculdade de Saúde Pública da USP]. 
89. WESTPHAL, M.F. Participação popular e políticas municipais de saúde: cotia e Vargem Grande Paulista, SP, 1992. [Tese de Live-Docência - Faculdade de Saúde Pública da USP].

90. WESTPHAL, M.F. 0 papel educativo do pediatra no tratamento e controle das alergias e imunodeficiências. In: Carneiro-sampaio, M.M.J. \& Grumach, A.S., coord. Alergia e imunologia em pediatria. São Paulo, Sarvier, 1992.

91. WEYNE, S. Cariologia. In: Baratieri, L.N. Dentistica: procedimentos preventivos e restauradores. Sāo Paulo, Santos, 1990. Cap. 1., p.1-42.

92. WINKLER, J.T. Opçōes práticas para uma política integrada do açúcar. Bibl. cient. ABOPREV, 2: 21-5, 1991. 
A NEXOS 
ANExo A - Formulārio das entrevistas

ANEXO B - Tabelas complementares de caracterização das mães entrevistadas

ANEXO C - Composição das classes sociais utilizadas no presente estudo

ANEXO D - Tabelas complementares sobre os cuidados com os filhos menores de 5 anos 


\section{A N E X O A}

\section{FORMULÁRIO PARA ENTREVISTA COM MĀES}

\section{IDENTIFICAÇÃO}

1 - $1^{\circ}$ Nome da mãe

2 - Qual é a sua idade?

3 - Onde você nasceu? Muñicipio anos

4 - o local onde você nasceu era: ( ) 1. Cidade ( ) 2. Campo

5 - Há quanto tempo você mora nesta cidade? anos: : ou

meses: :

(Caso a mãe more em outro município, especificar qual:....)

6 - Em que Bairro você mora?

7 - Estado marital: (o entrevistador deverá obter este dado através da seguinte pergunta:

\section{Você é casada?l}

( ) 1. Solteira com companheiro

( ) 2. Solteira sem companheiro

( ) 3. Casada com união estável

( ) 4. Casada vivendo só

( ) 5. Desquitada ou viúva com companheiro

( ) 6. Desquitada ou viúva sem companheiro

* se a mãe viver com o companheiro, perguntar:

8 - Tempo de união com o companheiro atual: anos: :

ou

meses:

\section{DADOS ESPECÍFICOS DE PARIDADE}

1 - Quantos filhos você (a senhora) tem?
( ) 1. um
( ) 2. dois
( ) 3 . três
( ) 4. quatro

( ) 5. outros, especificar:

2 - Quantos anos você tinha quando nasceu seu primeiro filho? anos:

3 - Quantos filhos têm até 5 anos de idade?
( ) 1. um
2. dois
(. ) 3. três

\begin{tabular}{|c|c|c|c|}
\hline $\begin{array}{c}\text { ORDEM DE } \\
\text { NASCIMENTO }\end{array}$ & $1^{\circ}$ NOME & $\begin{array}{l}\text { SEXO } \\
\text { MASC. } \\
\text { FEM. }\end{array}$ & $\begin{array}{l}\text { IDADE EM ANOS OU } \\
\text { MESES COMPLETOS }\end{array}$ \\
\hline $1^{\circ}$ & & & \\
\hline $2^{\circ}$ & & & \\
\hline $3^{\circ}$ & & & \\
\hline
\end{tabular}


(As perguntas seguintes referem-se às crianças com menos de 5 anos de idade)

4 - Onde a(s) criança(s) fica(m) durante o dia?

\begin{tabular}{|c|c|c|c|}
\hline & $1^{0}$ & $2^{\circ}$ & $3^{\circ}$ \\
\hline 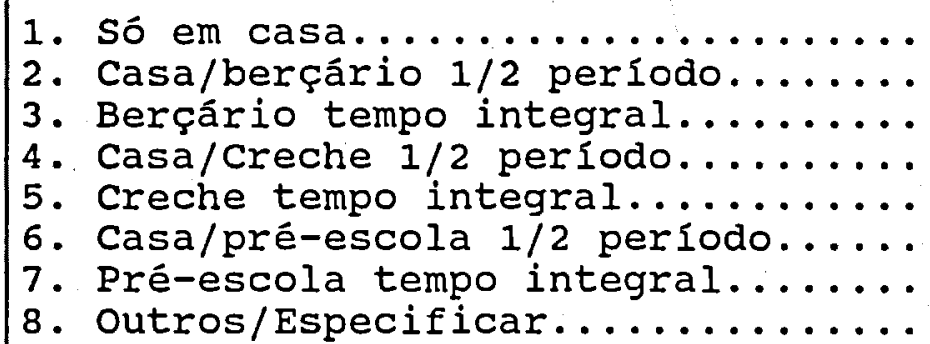 & & & \\
\hline
\end{tabular}

5 - Quando a criança está em casa quem cuida dela?

\begin{tabular}{|c|c|c|c|}
\hline & $1^{\circ}$ & $2^{\circ}$ & $3^{\circ}$ \\
\hline 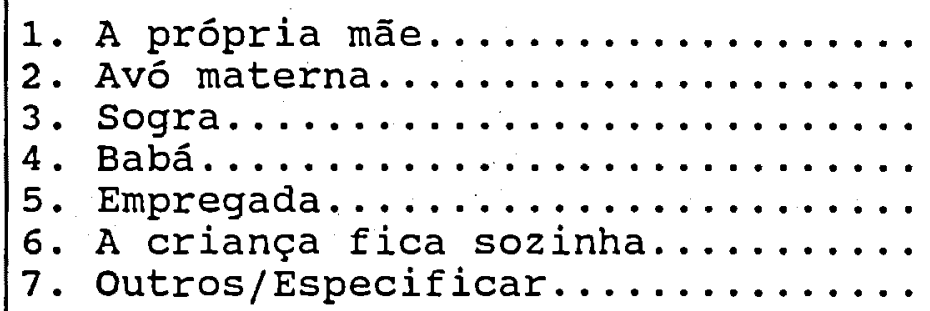 & & & \\
\hline
\end{tabular}

CONHECIMENTOS, ATITUDES E PRÄTICAS DA MĀE COM RELAÇĀO A SEUS FILHOS

1 - Atualmente como seu(s) filho(s) está de saúde?

\begin{tabular}{|c|c|c|c|}
\hline & & & \\
\hline & $1^{0}$ & $2^{\circ}$ & $3^{\circ}$ \\
\hline 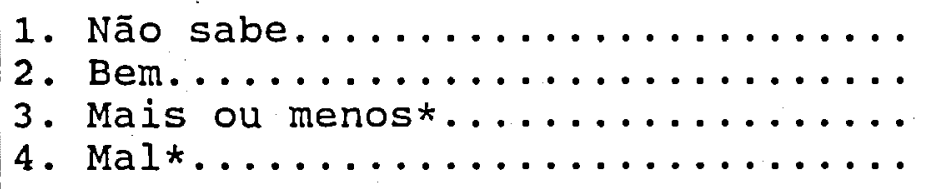 & & & \\
\hline
\end{tabular}

* Para Mais ou menos ou Mal peroguntar por que?....... 
2 - Durante quanto tempo, mais ou menos, você amamentou seu(s) filho(s) no peito.

\begin{tabular}{|c|c|c|c|}
\hline & $1^{\circ}$ & $2^{\circ}$ & $3^{\circ}$ \\
\hline 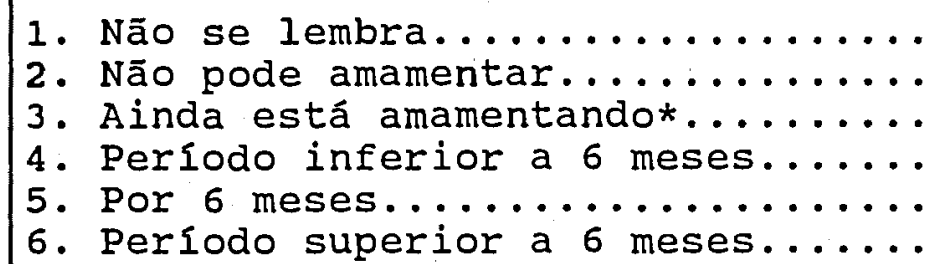 & & & \\
\hline
\end{tabular}

5

* Se for o único filho com menos de 5 anos de idade: ir para a pergunta

3 - Se não amamentou ou depois que parou de dar o peito, seu(s) filho(s) costumava(m) tomar mamadeira com leite ao dormir?

\begin{tabular}{|c|c|c|c|}
\hline & $1^{0}$ & $2^{\circ}$ & $3^{\circ}$ \\
\hline 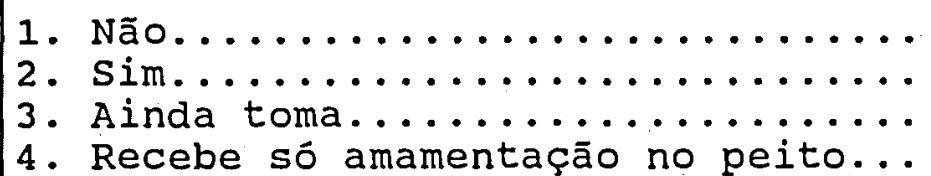 & & & \\
\hline
\end{tabular}

4 - Ao preparar a mamadeira, além do leite colocava alguma coisa?

( ) 1. Não ( ) 2. Sim. Perguntar o quê?

\begin{tabular}{|c|c|c|c|}
\hline & $1^{\circ}$ & $2^{\circ}$ & $3^{\circ}$ \\
\hline 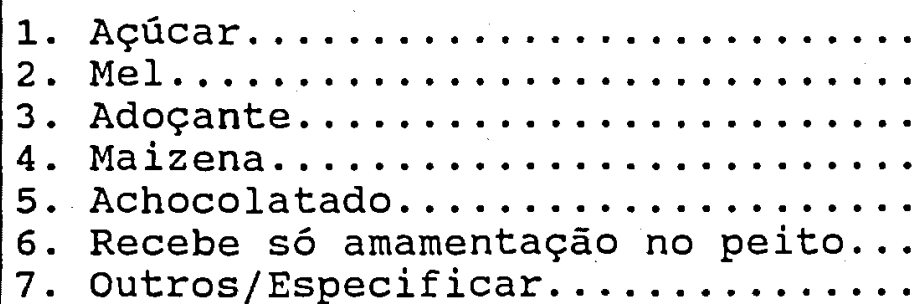 & & & \\
\hline
\end{tabular}

por que?. 
5 - Lembra quando "nasceu" o primeiro dente de leite de seu(s) filho(s)?

( ) 1. Ainda não nasceu

( ) 2. Não

( ) 3. Sim. Quando?

\begin{tabular}{|c|c|c|c|}
\hline & $1^{\circ}$ & $2^{\circ}$ & $3^{\circ}$ \\
\hline 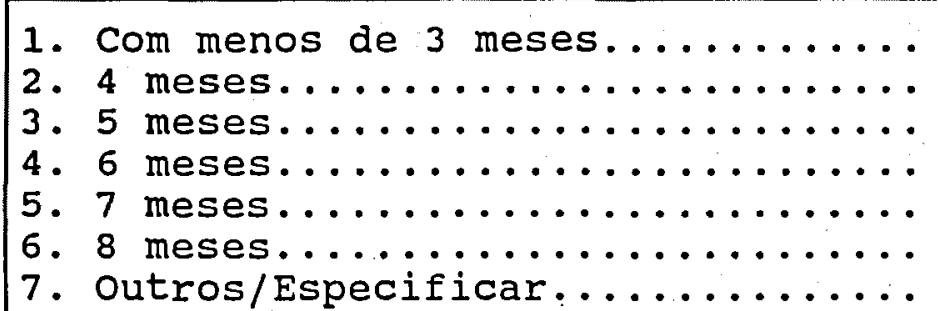 & & & \\
\hline
\end{tabular}

6 - Sabe dizer quantos dentes de leite as crianças têm?
( ) 1. Não
( ) 2. Sim. Quantos?.

Conhecimentos sobre os

dentes de leite

10 entrevistador não de-

( ) 1. $\mathrm{N}^{\circ}$ inferior a 20 dentes

( ) 2. 20 dentes

verá preencher este quadro( ) 3. $N^{0}$ superior a 20 dentes

7 - Na sua opinião para que servem os dentes de leite?

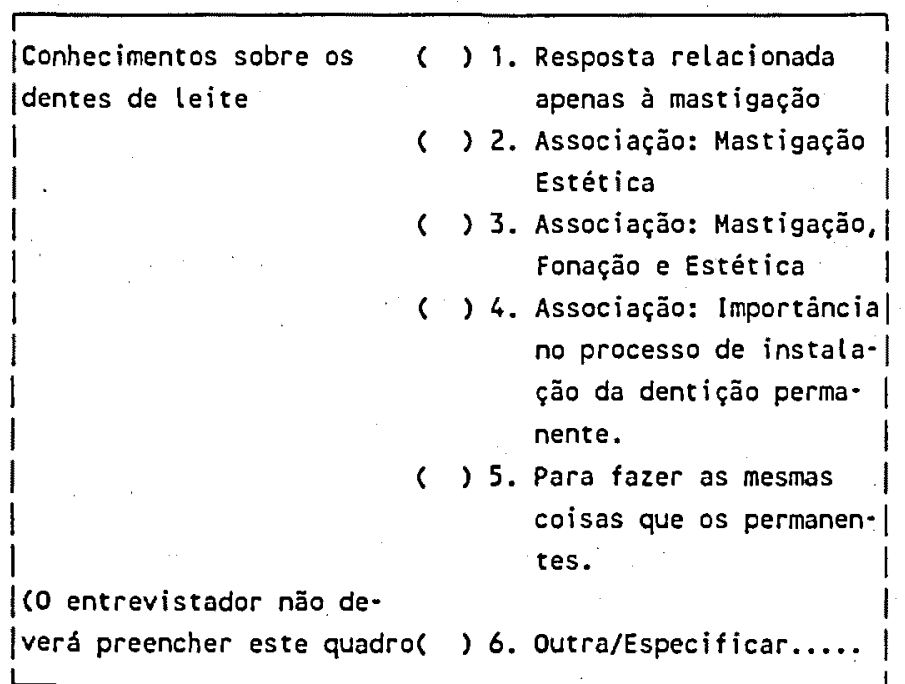


8 - Quando você limpou pela primeira vez os dentes de seu(s) filho(s)?

\begin{tabular}{|c|c|c|c|}
\hline & $1^{\circ}$ & $2^{\circ}$ & $3^{\circ}$ \\
\hline 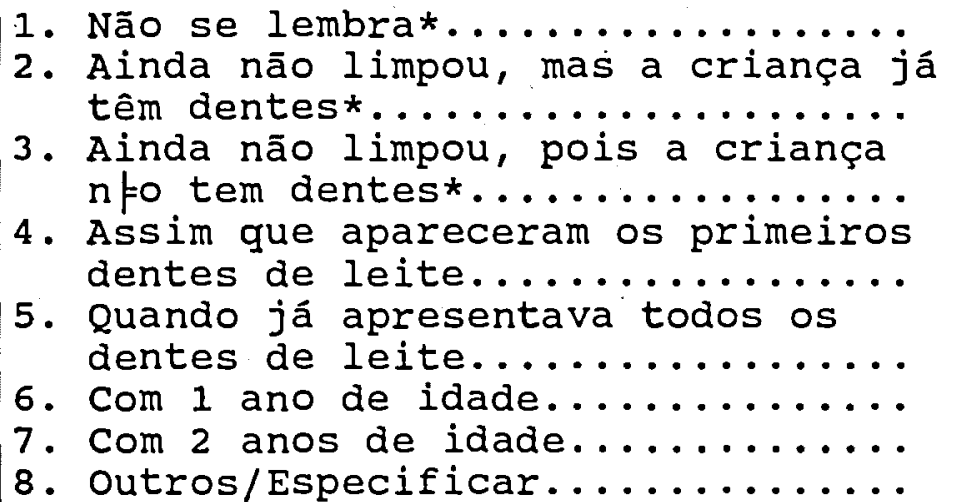 & & & \\
\hline
\end{tabular}

* Ir para a pergunta 11.

9 - No caso de já ter limpado, perguntar: como?

1. Com escova sem pasta.............

2. Com escova e pasta..............

3. Com escova, pasta e fio dental...

4. Fralda ou pano úmido............

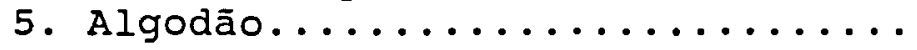

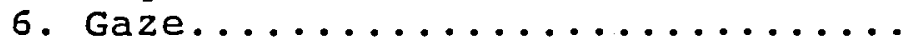

7. Outros/Especificar............

10 - Foi orientada para isso?

( ) 1. Não ( ) 2. Sim. Por quem?

( ) 1. Mãe (avó da criança)
( $)$ Leituras diversas
3. Dentista particular
( ) 4. Dentista - Srviços públicos
( ) 6. Médico particular
( ) 7. Outros - Serviços públicos

11 - Na sua opinião, em que época a criança deve começas a escovar seus próprios desntes?

( ) 1. Assim que nascerem os primeiros dentes de leite

( ) 2. Quando apresentar todos os dentes de leite na boca

( ) 3. Assim que possa aprender a escovar

( ) 4. A partir de 1 ano de idade

( ) 5. A partir de 2 anos de idade

() 6. Não sabe

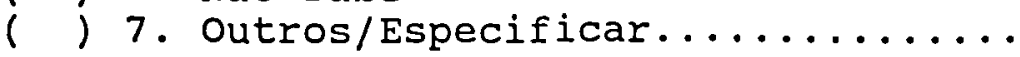


12 - Quantas vezes por dia ele deve escovar seus dentes?

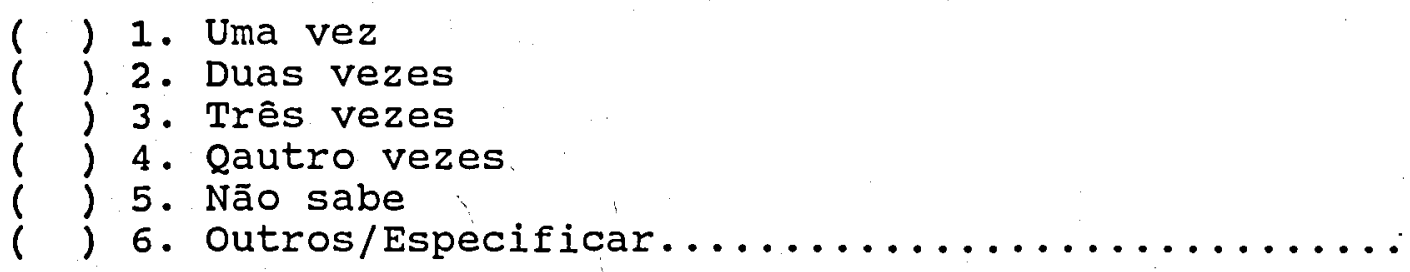

13 - Em que horários?
( ) 1. Ao acordar
( ) 2. Antes de dormir
( ) 3. Manhã/Tarde/Noite
( ) 4. Manhã/Tarde/Noite/Antes de dormir
( ) 5. Após as refeições: Café, Almoço, Jantar
( ) 6. Após o almoço e o jantar
( ) 7. Antes do café, após o almoço e jantar
( ) 8. Outros/Especificar

14 - Como você acha que está a limpeza dos dentes de seu(s) filho(s)?

\begin{tabular}{|c|c|c|c|}
\hline & $1^{0}$ & $2^{\circ}$ & $3^{\circ}$ \\
\hline 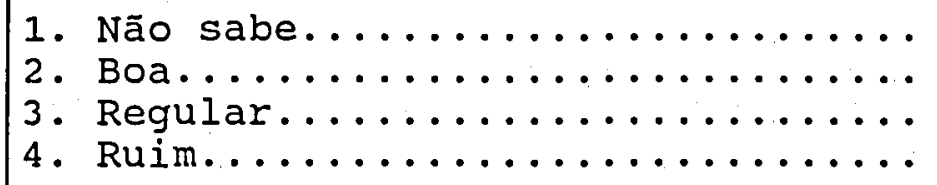 & & & \\
\hline
\end{tabular}

15 - Quantas refeições seu(s) filho(s) constuma(m) fazer por dia?

\begin{tabular}{|c|c|c|c|}
\hline & $1^{0}$ & $2^{\circ}$ & $3^{\circ}$ \\
\hline 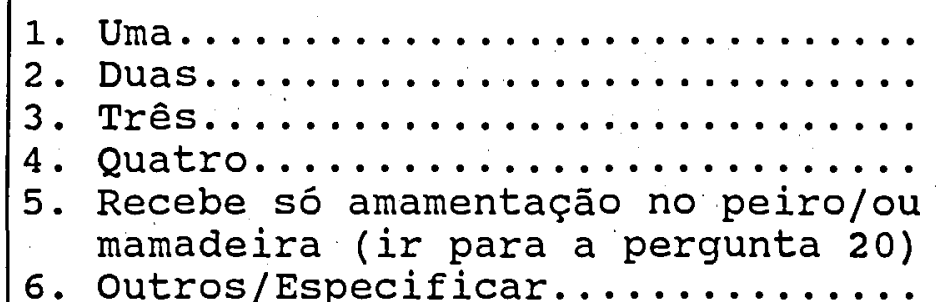 & & & \\
\hline
\end{tabular}


16 - Ele(s) costuma(m) comer fora das horas de refeiçōes?

\begin{tabular}{|c|c|c|c|}
\hline & $1^{\circ}$ & $2^{\circ}$ & $3^{0}$ \\
\hline 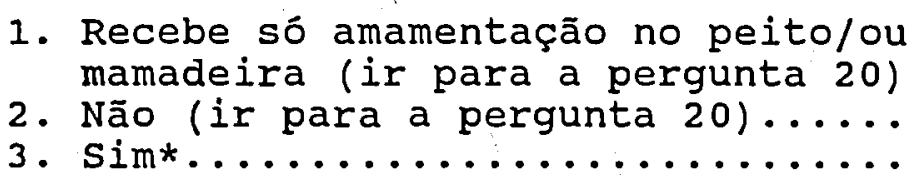 & & & \\
\hline
\end{tabular}

* Em caso de resposta afirmativa, Perguntar:

17 - 0 quê?

\begin{tabular}{|c|c|c|c|}
\hline & $1^{\circ}$ & $2^{\circ}$ & $3^{\circ}$ \\
\hline 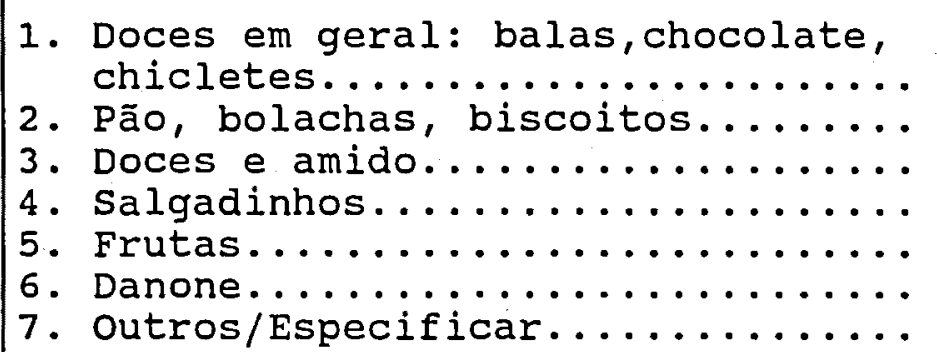 & & & \\
\hline
\end{tabular}

18 - Alguém oferece para ele(s)?

( ) 1. Não

( ) 2. Sim. Quem?

19 - O que acha dele(s) comer(em) nos intervalos das refeições?

20 - Acha que o tipo de alimentos que seu(s) filho(s) costuma(m) comer pode de alguma maneira prejudicar seus dentes?

1. Não sabe (ir para pergunta 24 )...

2. Não (ir para pergunta 24) ........

3. $\operatorname{sim} \ldots \ldots \ldots \ldots \ldots \ldots \ldots \ldots$

* Em caso de resposta afirmativa, perguntar:

21 - Como? 
22 - Você tem feito alguma coisa para evitar que ele(s) coma(m) nos intervalos?

\section{( ) 1. Não (ir para pergunta 24)}

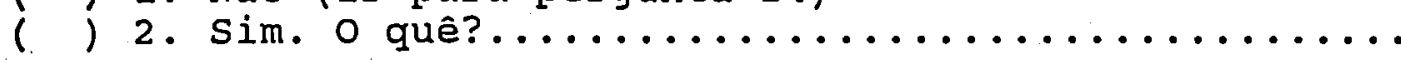

23 - Tem encontrado dificuldades para conseguir isto?

$$
\begin{aligned}
& \text { ( ) 1. Não sabe } \\
& \text { ( ) } 3 \text {. Não } \\
& \text { Sim. Quais? }
\end{aligned}
$$

( ) 1. A criança está acostumada (hábitos)

( ) 2. Resistência por parte da criança

( ) 3. A mãe tem dificuldade de comunicação com a criança

( ) 4. Falta de colaboração de outras pessoas da familia

( ) 5. Outras/Especificar..............

24 - Com que idade levou seu(s) filho(s) pela primeira vez ao dentista?

* (Relembrando: pergunta relativa aos filhos que no momento da entrevista apresentam até 5 anos de idade)

(O ENTREVISTADOR DEVER: UTILIZAR OS SEGUINTES CÓDIGOS PARA IDADE:)

\section{IDADE :}

$0 .<1$ ano

1. um ano

2. dois anos

3. três anos

4. quatro anos

5. cinco anos

6. ainda não levou

7. Não se lembra

\begin{tabular}{|c|c|c|c|}
\hline \multirow[b]{2}{*}{ MOTIVO } & \multicolumn{3}{|c|}{ IDADE } \\
\hline & $1^{\circ}$ & $2^{\circ}$ & $3^{\circ}$ \\
\hline $\begin{array}{l}\text { 1. Cárie............ } \\
\text { 2. Dor............... } \\
\text { 3. Traumatismo...... } \\
\text { 4. Avaliar se estava } \\
\text { tudo normal....... } \\
\text { 5. Prevenção(limpeza, } \\
\text { flúor............ } \\
\text { 6. Rotina escolar.... } \\
\text { 7. Outros/Especificar } \\
\text {.................. }\end{array}$ & & & \\
\hline
\end{tabular}

* (Se a mãe tem apenas um filho até 5 anos e ainda não levou ao dentista: ir para pergunta 35 )

25 - Quando costuma levar seu(s) filho(s) ao dentista?

26 - Nos últimos 6 meses procurou dentista para seu(s) filho(s)?

( ) 1. Não (ir para pergunta 35)

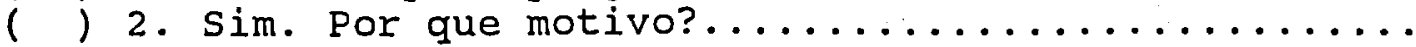


27 - Onde você procurou atendimento?
() 1.INAMPS
() 2.Posto de Saúde
(.) 3.Consultório Particular
4. Outro/Especificar

28 - Por quem foi atendido?

( ) 1.clinico Geral

() 2.odontopediatra

( ) 3.outro/Especificar

( ) 4. Não sabe

29 - Você entrou no consultório junto com seu filho?

( ) 1. Não

( ) 2.Sim. Por quê?

30 - o que achou do atendimento prestado?

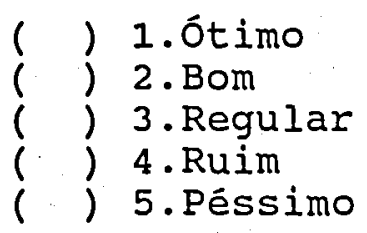

Por quê?.................

31 - Qual foi o comportamento de seu(s) filho(s)?

\begin{tabular}{|l|c|c|c|}
\cline { 2 - 4 } \multicolumn{1}{c}{} & $1^{\circ}$ & $2^{\circ}$ & $3^{\circ}$ \\
\hline 2. Normal/sem problemas/deixou atender & & & \\
3. Dicou trabalho/chorou............. & & & \\
4. Gostou de ter ido ao dentista..... & & & \\
5. Outro/Especificar............. & & & \\
\hline
\end{tabular}

32 - o dentista falou com você?

( ) 1. Não

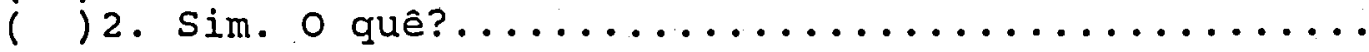

33 - Havia auxiliar dentário?

( ) 1. Nāo

( ). Sim. Ele(a) falou com você?

(. ) 1. Não

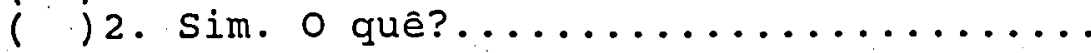


34 - Como você falou para seu filho que tinha consulta no dentista?

35 - Na sua opinião, as mães devem preparar as crianças para irem ao dentista?

( ) 1. Não sabe.

( ) 2. Não. Por quê?

36 - Você já ouviu falar do flúor?

( ) 1. Não (ir para a pergunta 40)

( )2. Sim. Onde?

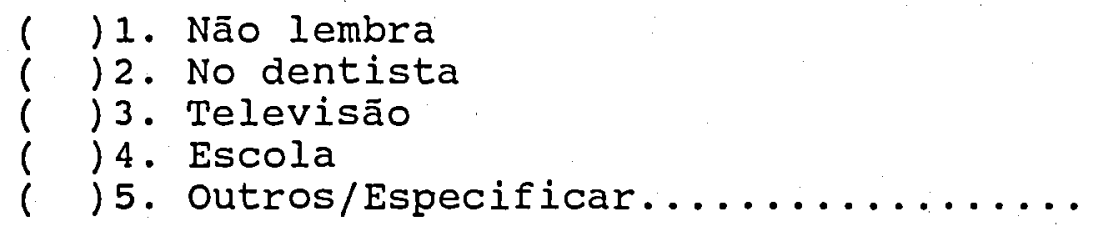

37 a 39 (só para as que ouviram falar, perguntar:)

37 - Para que serve o flúor?

( ) 1. Não sabe

( ). Evitar (combater) cáries

( ) 3. Proteção dos dentes (fortalecer)

( ) 4. Limpar os dentes

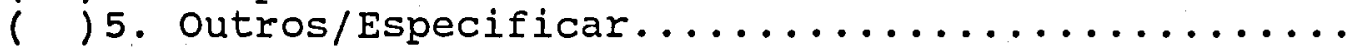

38 - Seu(s) filho(s) já fez (fizeram) uso de flúor?

( ) 1. Não sabe

( ) 2. Não.

( 3. Sim. De que forma?

( ) 1. Aplicação no dentista

( ) 2. Pasta de dente

( ) 3. Bochecho (escola)

(. ) 4. Outro/Especificar...............

39 - Maringá tem flúor na água de abastecimento público?

( ) 1. Não sabe

2. Não

( )3. Sim. Por quê acha que puseram flúor na água de

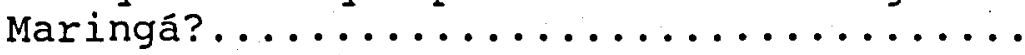


40 - Sabe dizer em que idade a criança começará a trocar seus dentes?

( ) 1. Não

( 2. Sim. Quando? ( )1. Entre 4-5 anos de idade

( ) 2. Entre 5-6 anos de idade

( ) 3. Aos 6 anos de idade

( 4. Entre 7-8 anos de idade

( ) 5. Outro/Especificar........

41 - Você sabe quais são as doenças da boca mais comuns?

( ) 1 . Não Sim. Quais são?

() 1. Cárie

( ) 2. Gengivite

( )3. Cárie/problemas periodontais

( ) 4. Máu hálito

()5. Afta

( )6. Outros/Especificar.............

42 - Já recebeu alguma explicação sobre o que é a cárie dentária?

( ) 1. Não

)2. Sim. De quem?

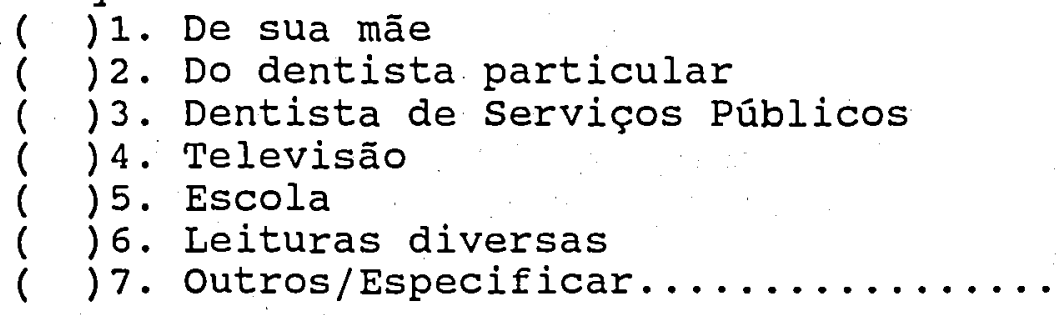

43 - Saberia dizer o que é a cárie dentária?

) 1. Não

). Sim. o que é?

\begin{tabular}{|c|c|}
\hline \multirow{2}{*}{$\begin{array}{l}\text { (PARA USO SOMENTE } \\
\text { DO. PESQUISADOR) }\end{array}$} & $\begin{array}{l}\text { 1. Relacionar a resposta com furo/buraco/ } \\
\text { perfuração }\end{array}$ \\
\hline & $\begin{array}{l}\text { 2. Relacionar com cor amarela/preta/escura } \\
\text { do dente }\end{array}$ \\
\hline & $\begin{array}{l}\text { 3. Relacionar com apodrecimento/dentes } \\
\text { estragados/destruidos } \\
\text { 4. Relacionar com falta de cuidado/higiene }\end{array}$ \\
\hline CONCEITO & 5. "Bichinho que come o dente" \\
\hline DE CÁRIE & 6. Relacionar com a presença de bactérias/ \\
\hline DENTÁRIA & placa bacteriana/microrganismos \\
\hline & $\begin{array}{l}\text { Comem os dentes } \\
\text { 7. Outras/Especificar.. }\end{array}$ \\
\hline
\end{tabular}


44 - Na sua opinião o que causa a cárie?

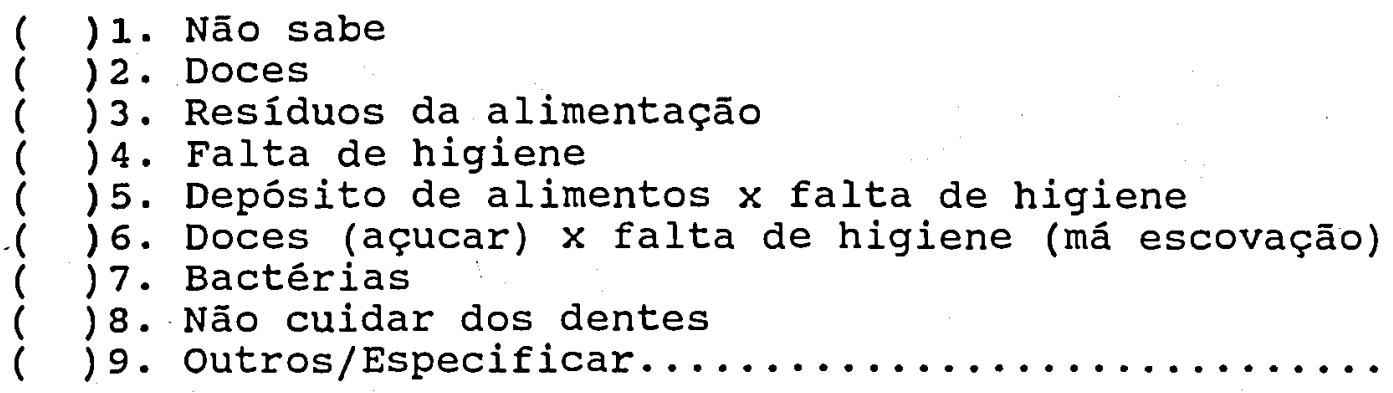

45 - Considera a cárie dentária: (o entrevistador deverá ler os itens A e B)

A - Normal, ou seja uma doença sem grandes consequências com a qual podemos conviver?

( ) 1 . Não

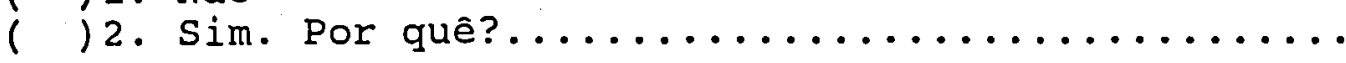

B - Uma doença de difícil solução?

( ) 1. Não

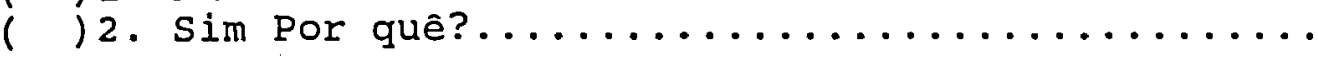

46 - Acha que a cárie dentária pode ser evitada?

( ) 1. Não sabe

( ) 2. Não

( )3. Sim. Como?

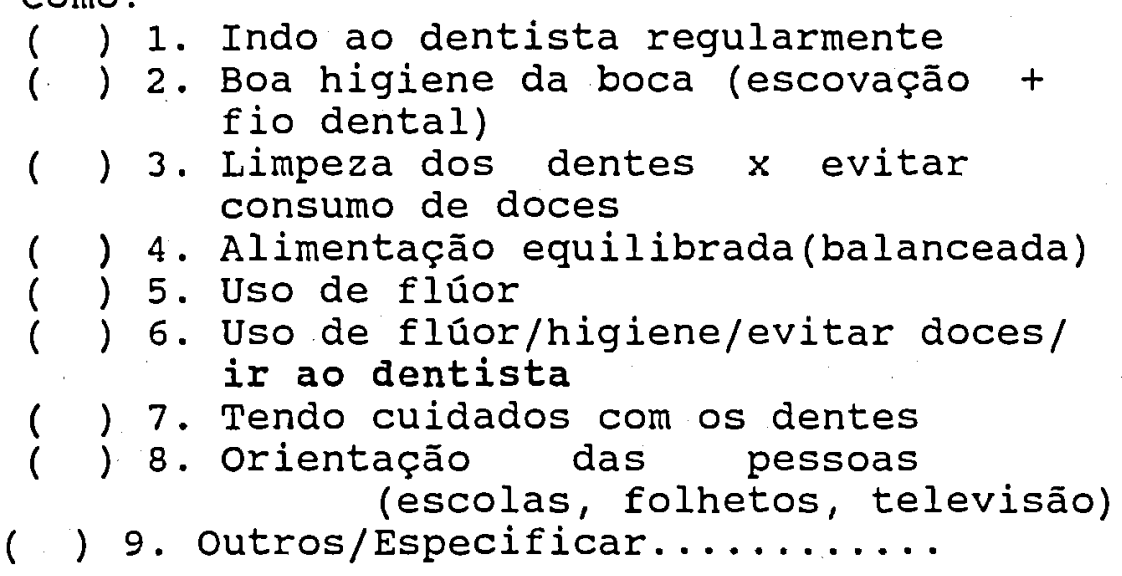

47 - Alguém ensinou você a escovar seus dentes?

( ) 1. Não

( )2. Sim. Quem? ( ) 1. Dentista particular

( ) 2. Dentista de Serviços Públicos

( ) 3. Sua mãe

() 4. Seu pai

( ) 5. Seus pais

() 6. Escola

( ) 7. Viu na televisão

( ) 8. Outros/Especificar......... 
48 - Alguém ensinou seu(s) filho(s) a escovar os dentes?

( ) 1. Não

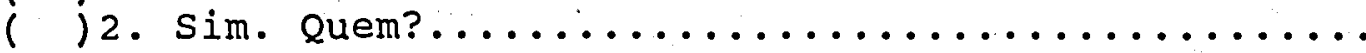

49 - Você tem costume de "beliscar" entre as refeiçōes?

( ) 1. Não

( )2. Sim. o que come nestes momentos?

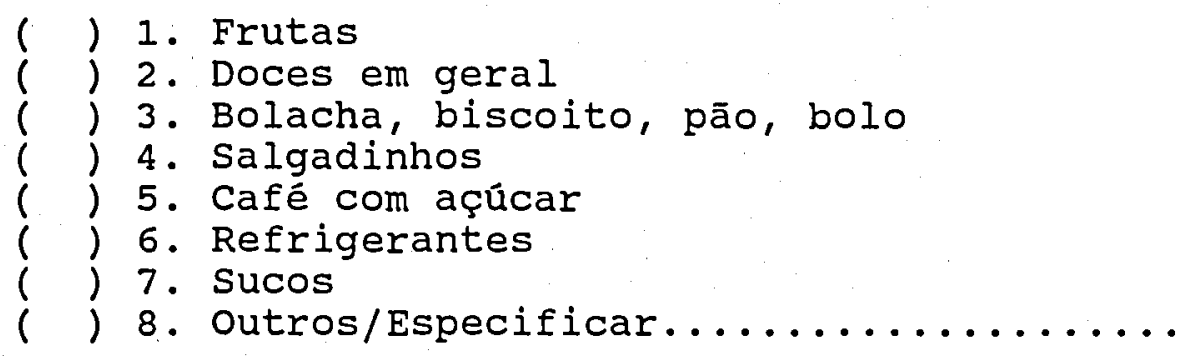

50 - Saberia dizer quantos dentes permanentes temos?

( ) 1. Não

( )2. Sim. Quantos? ( ) 1. Número inferior a 32

( ) 2. 32 dentes

( ) 3. Número superior a 32

51 - Você já perdeu algum dente permanente?

( ) 1. Não sabe

( ) 2. Não

( ) 3. Sim. Quantos?

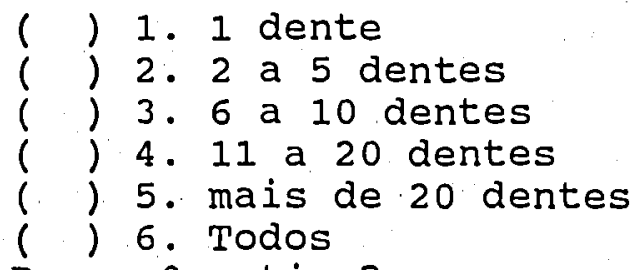

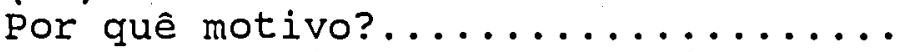

Como se sentiu por ter perdido?.....

52 - Geralmente, qual o motivo que a faz procurar um dentista?

( ) 1. Dor

( ) 2. Cárie

( )3. Problemas de gengiva

( ) 4. Cárie/problemas gengivais

( )5. Limpeza dos dentes

( ) 6. Controle/revisão

( 7. Manutenção dos dentes sadios

( ) 8. Estética

( ) 9. Prevenção de cárie e outros problemas

( ) 10.Só vai quando aparece algum problema, quando é realmente necessário

( ) 11.Preocupação em não perder mais dentes

( )12.Outros/Especificar. 
53 - Neste últimos 15 dias teve algum tipo de problema na boca?

( ) 1. Não sabe

). Não

( ) 3 . Sim. O quê?

)1. Dor de dente

) 2. Cárie

3. Problemas de gengiva

). Restauração caiu

)5. Precisa fazer canal

)6. Outros/Especificar.......

Está tratando?

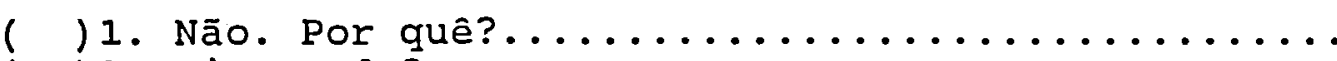

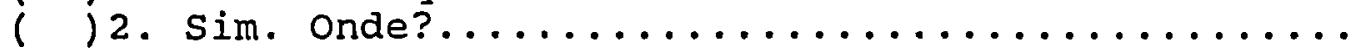

54 - Acha que problemas de boca podem afetar sua saúde?

( ) 1. Não sabe

( ) 2. Não

( )3. Sim. Por quê?.

$55-E$ a de seu(s) filho(s)?

( ) 1. Não sabe

( ) 2. Não

( 3. Sim. Por quê?

CONDIÇÕES SÓCIO-ECONÔMICAS

(Por último, eu gostaria de conversar com você sobre estudo e trabalho das pessoas que moram na sua casa)

1. Na sua casa quem é o chefe da família?

( ) 1. A própria mãe

(. ) 2. Companheiro

( ) 3 . O casal

( ). O pai dela

( )5. A mãe dela

( )6. Outros/Especificar. 
2. Quantas pessoas vivem na sua casa? _ 1 _
(o entrevistador deverá incluir todas as pessoas da casa)

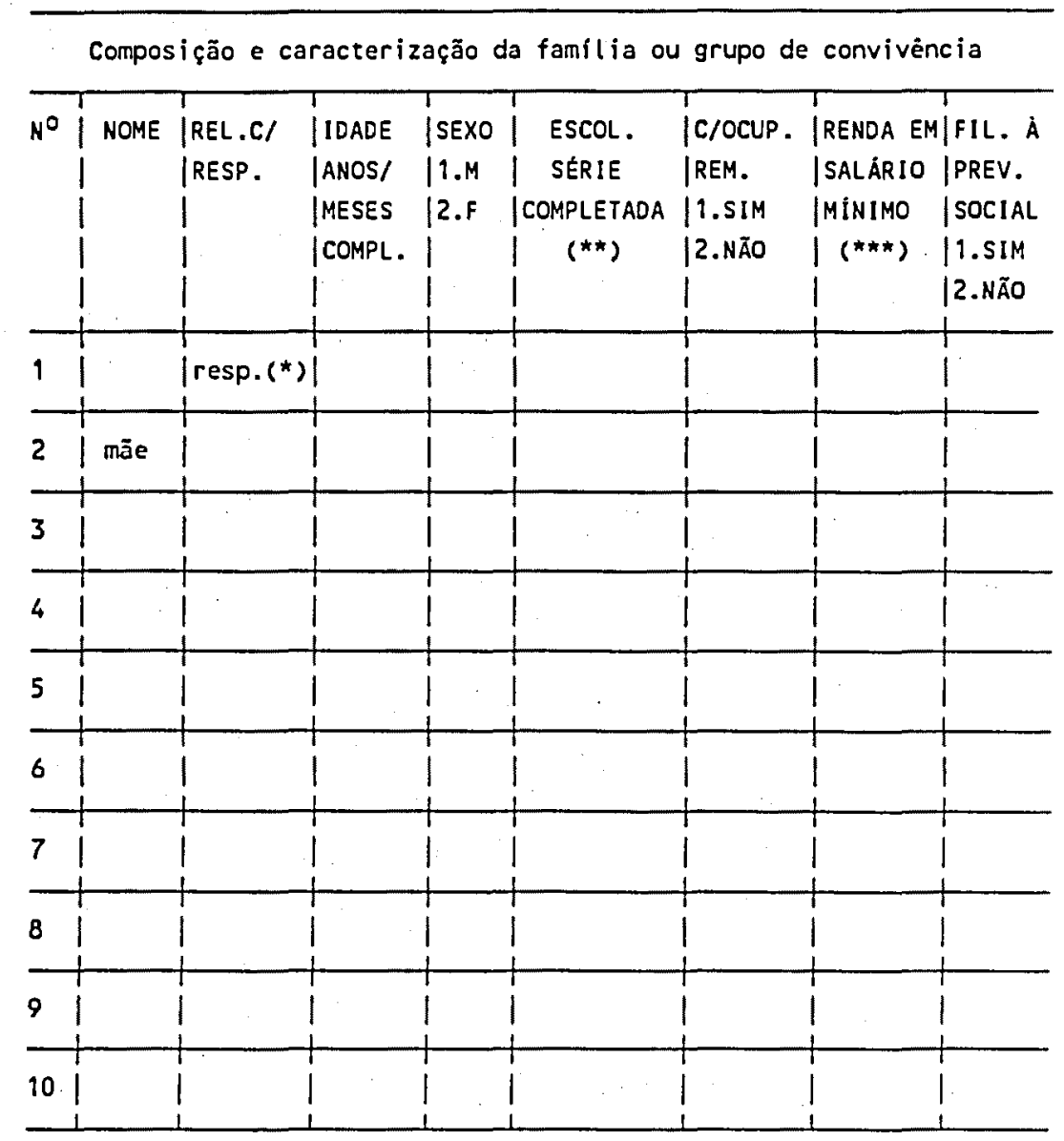

(*) No caso da mãe ser o responsável pelo sustento da familia ou por si mesma, anotar somente a partir da linha 2 registrando essa condição na coluna Relação com o responsável com termo "RESP".

O ENTREVISTADOR DEVERÁ UTLIZAR-SE DOS SEgUINTES CÓdIGOS PARA ESPECIFICAR A SITUAÇÃo DE ESCOLARIDADE:

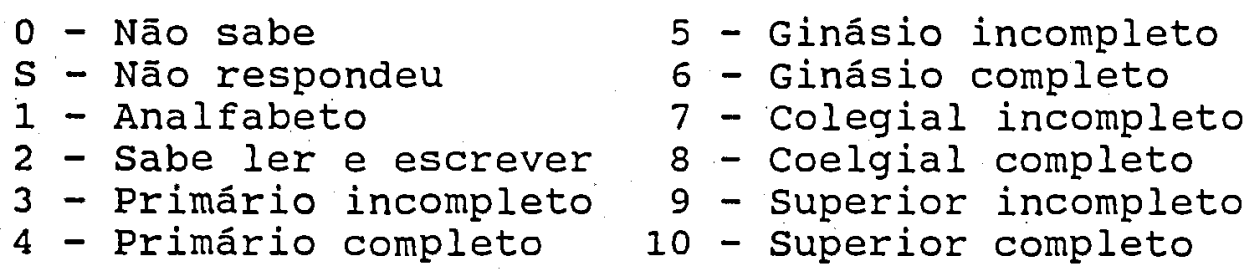


** O ENTREVISTADOR DEVERÁ UTLIZAR-SE DOS SEGUINTES CóDIGOS PARA ESPECIFICAR A RENDA EM SALÄRIOS MINIMOS:

$$
\begin{aligned}
& 1 \text { - Até 1 S.M. } \\
& 2 \text { - } 1 \text { S.M. } \\
& 3 \text { - } 3 \text { S.M. S.M. } \\
& 4 \text { - } 4 \text { S.M S.M. } \\
& 5 \text { - } 10 \text { e } 10 \text { S.M. } \\
& 6 \text { - Não sabe } \\
& 7 \text { - Não respondeu }
\end{aligned}
$$

3 - Ocupação principal da mãe e do responsável pelo "sustento da familia":

3.1. Descrever detalhadamente a ocupação principal no momento (ou a última nos casos de desemprego, aposentadoria, licenças, afastamento)

a) Da mãe:

(No caso dela estar trabalhando fora de casa, especificar: quantos dias/semana e quantas horas/dia permanece fora de casa para trabalhar)

- Especificar casos de trabalho precário ("bicos")/ atividades "marginais"/ e assemelhados

b) do chefe da familia:

- Qual tipo de firma onde ele trabalha ou trabalhou por último? (descreva o ramo de atividade)

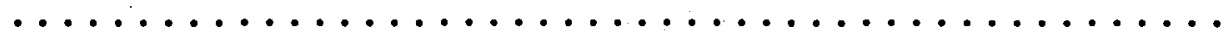

- Ele é empregado, patrão ou trabalha por conta própria?

( ) 1. Empregado

( ) 2. Patrão. Quantos empregados têm?..........

( ) 3. Conta própria (trabalho regular)

( 4 . Conta própria (trabalho irregular)

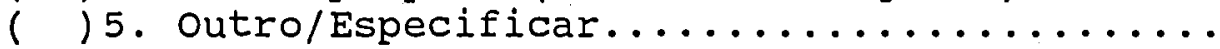

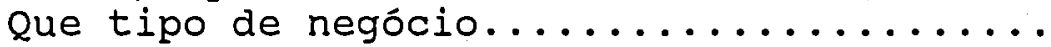


4 - Condição de atividade da mãe e do responsável,por ocasião da entrevista, em relação à diferentes formas de ocupação:

- Trabalhando de "forma regular"

Mãe Resp.Fam.

- Em licença.............. (esp.

- Afastada (0) . . . . .

- Desempregada (o).......... (esp. tipo em OBS)

- Subempregada (o) .......... (esp. tipo em OBS)

- Aposentada(o) senso lato.................

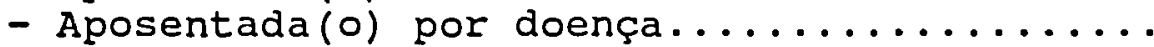

- Na caixa............... (esp. tipo em OBS)

- Incapacitada(o) p/o trabalho(esp.tipo em OBS)

- inativa (o) .............. (esp. tipo em oBS)

- Desocupada(o)........... (esp. tipo em oBS)

- Com atividade "marginal".. (esp. tipo em OBS)

- Estudante ..........................

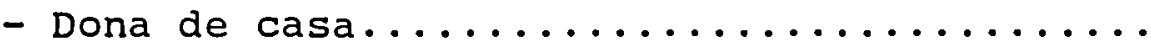

- outra................. (esp. tipo em oBs)

- Ignora.

$\begin{array}{rr}1 & \text { Resp. Fam } \\ 2 & 1 \\ 3 & 2 \\ 4 & 3 \\ 5 & 4 \\ 6 & 5 \\ 7 & 6 \\ 8 & 7 \\ 9 & 8 \\ 10 & 9 \\ 11 & 10 \\ 12 & 11 \\ 13 & 12 \\ 14 & 13 \\ 15 & 14 \\ 16 & 15 \\ & 16\end{array}$

\section{OBSERVAÇões (especificas para Pergunta $n^{\circ} 4$ )}

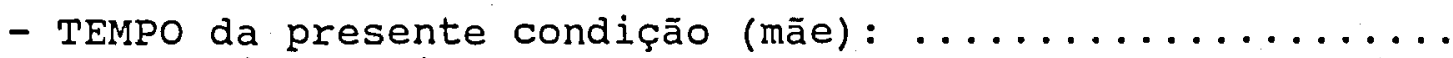

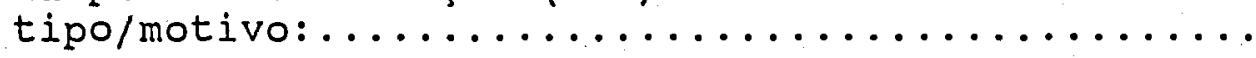

- TEMPo da presente condição (Resp. familia) : ..........

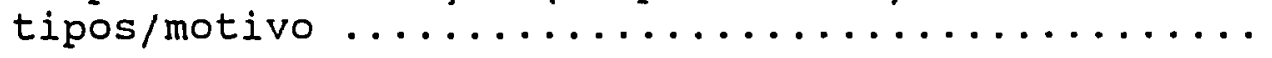

5 - De onde vem a água usada na sua casa?

( )1. Rede Pública - com torneira dentro de casa

( )2. Rede pública - sem torneira dentro de casa

( ) 3. Poço

( 4. Outros/Especificar. 

A N E X O
B

\section{TABELAS COMPLEMENTARES DE CARACTERIZAÇÃO DAS MÃES ENTREVISTADAS}

TABELA 1 - Distribuiçāo das mães segundo o município de nascimento.

TABELA 2 - Distribuição das māes segundo a procedência do municipio de nascimento.

TABELA 3 - Distribuição das mães segundo 0 tempo de residência em Maringá.

TABELA 4 - Número de moradores do domicilio por familia.

TABELA 5 - Distribuiçāo das māes segundo a condição de atividades.

TABELA 6 - Escolaridade do responsável pelo sustento da familia.

TABELA 7 - Condição de atividade do responsável pelo sustento da familia.

TABELA 8 - Classificação da ocupação do responsável pelo sustento da familia.

TABELA 9 - Distribuição das mães segundo a situação de trabalho do responsável pelo sustento da familia. 
TABELA 1 - Distribuição das mães segundo o município do nascimento.

\begin{tabular}{l|rr}
\hline MUNICIPIo & Freq & $\%$ \\
\hline Microregiao de Maringá & 263 & $47.5 \%$ \\
Município de Maringá & 142 & $25.6 \%$ \\
Outros Municipios/Paraná & 42 & $7.6 \%$ \\
Municípios outros Estados & 107 & $19.3 \%$ \\
\hline Total & 554 & $100.0 \%$ \\
\hline
\end{tabular}

TABELA 2 - Distribuição das mães segundo a procedência do municipio de nascimento.

\begin{tabular}{l|cc}
\hline MUNICÍPIO & Freq & $\%$ \\
\hline Urbana & 383 & $69.1 \%$ \\
Rural & 171 & $30.9 \%$ \\
\hline Total & 554 & $100.0 \%$ \\
\hline
\end{tabular}


TABELA 3 - Distribuição das mães segundo o tempo de residência em Maringá.

\begin{tabular}{l|rc}
\hline Tempo de residência & Freq & $\%$ \\
\hline MENOS DE 5 & 114 & $20.6 \%$ \\
$5-9$ & 54 & $9.7 \%$ \\
$10-14$ & 67 & $12.1 \%$ \\
$15-19$ & 102 & $18.4 \%$ \\
$20-24$ & 75 & $13.5 \%$ \\
$25-29$ & 45 & $8.1 \%$ \\
$30-49$ & 21 & $3.8 \%$ \\
Não respondeu & 554 & $100.0 \%$ \\
\hline Total &
\end{tabular}

TABELA 4 - Número de moradores do domicílio por família.

\begin{tabular}{l|rc}
\hline MORADORES & Freq & $\%$ \\
\hline Até 4 & 394 & $71.1 \%$ \\
$5-8$ & 148 & $26.7 \%$ \\
$9 \mathrm{e}+$ & 12 & $2.2 \%$ \\
\hline Total & 554 & $100.0 \%$ \\
\hline
\end{tabular}


TABELA 5 - Distribuição das mães segundo a condição de atividade.

\begin{tabular}{l|rc}
\hline ATIVIDADE & Freq & $\%$ \\
\hline Trabalho regular & 164 & $29.6 \%$ \\
Do lar & 308 & $55.6 \%$ \\
Desempregado/Subempregado & 37 & $6.7 \%$ \\
Atividade marginal & 16 & $2.9 \%$ \\
Afastado/Licença & 11 & $2.0 \%$ \\
Estudante & 6 & $1.1 \%$ \\
Outros & 8 & $0.7 \%$ \\
Não respondeu & 554 & $100.0 \%$ \\
\hline Total & & $1.4 \%$ \\
\hline
\end{tabular}

TABELA 6 - Escolaridade do responsável pelo sustento da familia.

\begin{tabular}{l|rr}
\hline ESCOLARIDADE & Freq & $\%$ \\
\hline Analfabeto/Sabe ler e escrever & 27 & $4.9 \%$ \\
10.Grau incompleto & 229 & $41.4 \%$ \\
10.Grau completo & 72 & $13.0 \%$ \\
20.Grau incompleto & 29 & $5.2 \%$ \\
20.Grau completo & 99 & $17.9 \%$ \\
30.Grau incompleto & 34 & $6.1 \%$ \\
3o.Grau completo & 54 & $9.7 \%$ \\
Não sabe & 10 & $1.8 \%$ \\
\hline Total & 554 & $100.0 \%$ \\
\hline
\end{tabular}


TABELA 7 - Condição de atividade do responsável pelo sustento da familia.

\begin{tabular}{l|rr}
\hline ATIVIDADE & Freq & $\%$ \\
\hline TRABALHADOR REGULAR & 472 & $85.2 \%$ \\
DESEMPREGADO/SUBEMPREGADO & 24 & $4.3 \%$ \\
APOSENTADO & 11 & $2.0 \%$ \\
ATIVIDADE MARGINAL & 9 & $1.6 \%$ \\
OUTRAS & 6 & $1.1 \%$ \\
NÃO RESPONDEU & 32 & $5.8 \%$ \\
\hline TOtaI & 554 & $100.0 \%$ \\
\hline
\end{tabular}


TABELA 8 - classificação da ocupação do responsável pelo sustento da familia.

\begin{tabular}{|c|c|c|}
\hline OCUPAÇĀO & Freq & $\%$ \\
\hline rof.Nível superior (formação universitária) & 20 & $3.6 \%$ \\
\hline $\begin{array}{l}\text { Trabalhador de ensino, artes e assemelhados; } \\
\text { técnicos( } 20 . \text { Grau) }\end{array}$ & 19 & $3.4 \%$ \\
\hline $\begin{array}{l}\text { Funcionários administrativos setor público/ } \\
\text { privado }\end{array}$ & 15 & $2.7 \%$ \\
\hline $\begin{array}{l}\text { Trabalhos diretos no processo de produção } \\
\text { agropecuária }\end{array}$ & 27 & $5.0 \%$ \\
\hline Trabalhador no processo produção industrial & 89 & $16.1 \%$ \\
\hline $\begin{array}{l}\text { Trabalhador na área administrativa nivel } \\
\text { intermediário e inferior }\end{array}$ & 50 & $9.0 \%$ \\
\hline Vendedores & 86 & $15.5 \%$ \\
\hline $\begin{array}{l}\text { Auxiliar; ajudantes e serventes em comércio } \\
\text { e serviços ao público }\end{array}$ & 29 & $5.2 \%$ \\
\hline $\begin{array}{l}\text { Trabalhador em serviços ao público e serviços } \\
\text { pessoais; exceto domésticos }\end{array}$ & 67 & $12.1 \%$ \\
\hline Trabalhadores em serviços domésticos & 14 & $2.5 \%$ \\
\hline Administradores, gerentes e proprietários & 18 & $3.2 \%$ \\
\hline operadores de equipamentos de transporte & 39 & $7.0 \%$ \\
\hline $\begin{array}{l}\text { Trabalhadores das forças armadas; serviços } \\
\text { de proteção e vigilância }\end{array}$ & 30 & $5.4 \%$ \\
\hline $\begin{array}{l}\text { Trabalhador em ocupação insuficiente } \\
\text { especificada }\end{array}$ & 24 & $4.3 \%$ \\
\hline Não respondeu & 27 & $5.0 \%$ \\
\hline Total & 554 & $100.0 \%$ \\
\hline
\end{tabular}


TABELA 9 - Distribuição das mães segundo a situação de trabalho do responsável pelo sustento da familia.

\begin{tabular}{l|rr}
\hline SITUAÇÃO & Freq & $\%$ \\
\hline EMPREGADO & 377 & $68.1 \%$ \\
PATRĀO & 45 & $8.1 \%$ \\
CONTA PRÓPRIA (trabalho regular) & 88 & $15.9 \%$ \\
CONTA PRÓPRIA (trabalho irregular) & 23 & $4.2 \%$ \\
OUTROS & 19 & $3.4 \%$ \\
NĀO RESPONDEU & 2 & $0.4 \%$ \\
\hline TOtal & 554 & $100.0 \%$ \\
\hline
\end{tabular}


COMPOSIÇĀO DAS CLASSES SOCIAIS UTILIZADAS NO PRESENTE ESTUDO

Proletariado: "inclui agentes sociais que, estando submetidos a uma relação de exploração, não exercem eles mesmos nem direta, nem indiretamente função de exploração. Trata-se de trabalhadores que: não dispōem de meios de produção e de trabalho e vendem sua força de trabalho para poder sobreviver; são objeto da extração de uma proporção do produto de seu trabalho e nāo possuem formação de nível superior. De acordo com a natureza e forma concreta como os individuos realizam seu trabalho, distinguem-se dois diferentes sub-conjuntos: proletariado tipico, composto por trabalhadores que desempenham atividades diretamente vinculadas com a produção e o transporte de mercadorias (pedreiros, operários, motoristas) e proletariado não tipico, formado por assalariados que somente têm relação indireta com a produção (bancários, trabalhadores de escritório, funcionários públicos)".

Nova pequena burguesia: "situaçāo de classe" que engloba os agentes sociais que ocupam os postos de mais alto nIvel técnico e de tomada de decisões, especificamente: "os trabalhadores assalariados que desempenham, no plano 
econômico, funçōes próprias do capital, como são as de direção, organização e vigilância do processo de trabalho e da produção; os assalariados que exercem funções de direção dentro do setor público; os assalariados que exercem funçōes as quais, apesar de não serem de direção, requerem formação profissional de nivel superior; e os profissionais autônomos, que são portadores de práticas especializadas que thes permitem vender seu trabalho, ainda que não sua força de trabalho".

Pequena burguesia tradicional: é composta pelos agentes sociais que "sem possuir formação universitária, possuem a capacidade de reproduzir-se de maneira independente, por disporem de meios de produção próprios. A reprodução desta classe baseia-se na utilização da força de trabalho do grupo familiar".

Subproletariado: inclui todos os agentes sociais "que desempenham uma atividade, predominantemente, não assalariada, em geral instável, com a qual obtêm salários e/ou rendimentos inferiores ao custo mínimo de produção da força de trabalho".

Burguesia: é constituída por "proprietários de meios de produção que, sem estar eles mesmos sujeitos à exploração, empregam força de trabalho assalariada, exercendo uma função de exploração do tipo capitalista, que se expressa na apropriação de uma porção de tempo de trabalho do operário. Empregam cinco ou mais pessoas e têm renda individual superior a quinze salários mínimos". 


\section{A $N$ E X O D}

\section{TABELAS COMPLEMENTARES SOBRE OS CUIDADOS COM OS FILHOS MENORES DE 5 ANOS}
TABELA 1 - Distribuiçāo dos filhos menores de 5 anos de idade segundo o local de permanência durante o dia.

TABELA 2 - Distribuição dos filhos maiores de 5 anos de idade de acordo com a pessoa responsável pelos cuidados com os mesmos em caixa. 
TABELA 1 - Distrioulçao dos filhos menores de 5 anos de idade segundo $o$ local de permanência durante 0 dia.

\begin{tabular}{l|rc}
\hline Local & Freq & \multicolumn{1}{c}{$\%$} \\
\hline Só em casa & 510 & $73.6 \%$ \\
Casa/berçário-meio periodo & 4 & $0.6 \%$ \\
Berçário tempo integral & 4 & $0.6 \%$ \\
Casa/creche-meio periodo & 12 & $1.7 \%$ \\
Creche periodo integral & 64 & $9.2 \%$ \\
Casa/pré-escola-meio período & 74 & $10.7 \%$ \\
Pré-escola periodo integral & 5 & $0.7 \%$ \\
Outros & 20 & $2.9 \%$ \\
\hline Total & 693 & $100.0 \%$ \\
\hline
\end{tabular}

TABELA 2 - Distribuição dos filhos menores de 5 anos de idade de acordo com a pessoa responsável pelos cuidados com os mesmos em casa.

\begin{tabular}{l|rc}
\hline RESPONSÁVEL & Freq & $\%$ \\
\hline Própria mãe & 530 & $76.5 \%$ \\
Avó materna & 63 & $9.1 \%$ \\
Sogra & 10 & $1.4 \%$ \\
Babá & 27 & $3.9 \%$ \\
Empregada & 28 & $4.0 \%$ \\
Criança sozinha & 2 & $0.3 \%$ \\
Outros & 33 & $4.8 \%$ \\
\hline Total & 693 & $100.0 \%$ \\
\hline
\end{tabular}

